Siegel, R. B., P. Pyle, J. H. Thorne, A. J. Holguin, C. A. Howell, S. Stock, and M. W. Tingley. 2014. Vulnerability of birds to climate change in California's Sierra Nevada. Avian Conservation and Ecology 9(1): 7. http://dx.doi.org/10.5751/ACE-00658-090107

Copyright $(\mathrm{C} 2014$ by the author(s). Published here under license by the Resilience Alliance.

Research Paper

\title{
Vulnerability of birds to climate change in California's Sierra Nevada
}

Rodney B. Siegel ${ }^{1}$, Peter Pyle ${ }^{1}$, James H. Thorne ${ }^{2}$, Andrew J. Holguin ${ }^{2}$, Christine A. Howell ${ }^{3}$, Sarah Stock ${ }^{4}$ and Morgan W. Tingley ${ }^{1,5}$ ${ }^{1}$ The Institute for Bird Populations, ${ }^{2}$ Dept. of Environmental Science and Policy, University of California, Davis, ${ }^{3}$ Pacific Southwest Region, USDA Forest Service, ${ }^{4}$ Yosemite National Park, ${ }^{5}$ Princeton University

\begin{abstract}
In a rapidly changing climate, effective bird conservation requires not only reliable information about the current vulnerability of species of conservation concern, but also credible projections of their future vulnerability. Such projections may enable managers to preempt or reduce emerging climate-related threats through appropriate habitat management. We used NatureServe's Climate Change Vulnerability Index (CCVI) to predict vulnerability to climate change of 168 bird species that breed in the Sierra Nevada mountains of California, USA. The CCVI assesses species-specific exposure and sensitivity to climate change within a defined geographic area, through the integration of (a) species' range maps, (b) information about species' natural history traits and ecological relationships, (c) historic and current climate data, and (d) spatially explicit climate change projections. We conducted the assessment under two different downscaled climate models with divergent projections about future precipitation through the middle of the 21 st century. Assessments differed relatively little under the two climate models. Of five CCVI vulnerability ranking categories, only one species, White-tailed Ptarmigan (Lagopus leucura), received the most vulnerable rank, Extremely Vulnerable. No species received the second-highest vulnerability ranking, Highly Vulnerable. Sixteen species scored as Moderately Vulnerable using one or both climate models: Common Merganser (Mergus merganser), Osprey (Pandion haliaetus), Bald Eagle (Haliaeetus leucocephalus), Northern Goshawk (Accipiter gentilis), Peregrine Falcon (Falco peregrinus), Prairie Falcon (Falco mexicanus), Spotted Sandpiper (Actitis macularius), Great Gray Owl (Strix nebulosa), Black Swift (Cypseloides niger), Clark's Nutcracker (Nucifraga columbiana), American Dipper (Cinclus mexicanus), Swainson's Thrush (Catharus ustulatus), American Pipit (Anthus rubescens), Gray-crowned Rosy-Finch (Leucosticte tephrocotis), Pine Grosbeak (Pinicola enucleator), and Evening Grosbeak (Coccothraustes vespertinus). Species associated with alpine/subalpine habitats and aquatic habitats received significantly more vulnerable rankings than birds associated with other habitats. In contrast, species of foothill, sagebrush, and chaparral habitats ranked as less vulnerable than other species, and our results suggest these species may respond to climate change in the region with population increases or range expansions.
\end{abstract}

\section{Vulnérabilité des oiseaux aux changements climatiques dans la Sierra Nevada en Californie}

RÉSUMÉ. Dans le contexte d'un climat qui change rapidement, la conservation efficace des oiseaux passe non seulement par un besoin d'information fiable sur la vulnérabilité actuelle des espèces préoccupantes, mais également par des projections crédibles de leur vulnérabilité future. Les projections de ce type peuvent permettre aux gestionnaires d'écarter ou d'amoindrir les menaces qui se profilent en raison du climat grâce à une gestion appropriée de l'habitat. Nous avons utilisé l'indice de vulnérabilité aux changements climatiques (CCVI pour Climate Change Vulnerability Index) de NatureServe afin de prévoir la vulnérabilité aux changements climatiques de 168 espèces d'oiseaux qui nichent dans la Sierra Nevada en Californie, aux États-Unis. Le CCVI détermine le degré d'exposition et de sensibilité aux changements climatiques spécifiques aux espèces dans une région géographique donnée par l'intégration des éléments suivants : a) la répartition de l'espèce; b) les caractéristiques de l'histoire naturelle et les relations écologiques de l'espèce; c) les données climatiques historiques et actuelles; et d) des projections des changements climatiques spatialement explicites. Nous avons effectué nos évaluations selon deux modèles climatiques ayant des projections divergentes pour les précipitations jusqu'au milieu du 21 e siècle. Les résultats différaient relativement peu selon les deux modèles. Parmi les cinq catégories de vulnérabilité du CCVI, seulement une espèce, le Lagopède à queue blanche (Lagopus leucura), s'est classée au rang de vulnérabilité le plus élevé, soit « extrêmement vulnérable ». Aucune espèce n'a figuré au second rang, soit « très vulnérable ». Seize espèces ont été classées comme « moyennement vulnérables » selon un des deux modèles ou les deux : Grand Harle (Mergus merganser), Balbuzard pêcheur (Pandion haliaetus), Pygargue à tête blanche (Haliaeetus leucocephalus), Autour des palombes (Accipiter gentilis), Faucon pèlerin (Falco peregrinus), Faucon des prairies (Falco mexicanus), Chevalier grivelé (Actitis macularius), Chouette lapone (Strix nebulosa), Martinet sombre (Cypseloides niger), Cassenoix d'Amérique (Nucifraga columbiana), Cincle d'Amérique (Cinclus mexicanus), Grive à dos olive (Catharus ustulatus), Pipit d'Amérique (Anthus rubescens), Roselin à tête grise (Leucosticte tephrocotis), Durbec des sapins (Pinicola enucleator) et Gros-bec errant (Coccothraustes vespertinus). Les espèces associées aux milieux alpins/subalpins et aux milieux aquatiques ont été classées dans des catégories de vulnérabilité plus élevées que les espèces fréquentant d'autres milieux, et ce de façon significative. À l'opposée, les espèces associées aux contreforts, aux armoises et au chaparral se sont vues attribuées des rangs de vulnérabilité moins élevés que les autres espèces, et nos résultats montrent que ces espèces réagiront peut-être aux changements climatiques par une augmentation de leurs populations ou une expansion de leur répartition.

Key Words: birds; climate change vulnerability; Sierra Nevada 


\section{INTRODUCTION}

In a rapidly changing climate, effective management of bird populations and their habitats requires not only reliable data about the current status and vulnerability of species of conservation concern, but also credible projections of future status and vulnerability. Future projections may allow managers to address emerging threats proactively, and, where possible, preempt or reduce them through thoughtful and appropriate habitat management. Integrating spatially explicit climate projections with information about the current distribution and ecology of plant and animal species provides an approach for predicting how vulnerable different organisms are likely to be to climate change (Hansen and Hoffman 2011).

Anthropogenic climate change is already evident across mountainous regions of the western United States (Bonfils et al. 2008), and the rate of change is expected to increase in the coming decades (Hayhoe et al. 2004, IPCC 2007, Cayan et al. 2008, Thorne et al. 2012). In our study region, the Sierra Nevada mountains of California, USA, climate models uniformly project warming temperatures, with variation only in the magnitude of warming, while projected changes in precipitation and other moisture metrics vary more widely (Cayan et al. 2008, Thorne et al. 2012). Regardless of whether precipitation decreases greatly, warming is expected to result in more precipitation falling as rain rather than snow (Hayhoe et al. 2004), and greatly reduced endof-winter snowpack because more runoff and flooding occurs during winter (Knowles and Cayan 2004, Dettinger et al. 2004). The magnitude of the reduction in snowpack and increases in winter runoff are expected to be highly variable across elevations and subregions (Dettinger et al. 2004, Maurer 2007), but will yield reduced spring and summer streamflows across the region (Knowles and Cayan 2002, Hayhoe et al. 2004). Throughout the 21 st century, climate change is projected to decrease the area of montane and subalpine conifer forest in the Sierra Nevada, and increase the amount of grassland and oak/pine vegetation (Lenihan et al. 2008, PRBO Conservation Science 2011).

Long-term anthropogenic climate change may threaten bird populations through factors such as habitat change and emerging mismatches between bird life-cycle phenology and prey availability (Both et al. 2006, Huntley et al. 2008, Möller et al. 2008). In California, Stralberg et al. (2009) predicted that climate change is likely to yield large shifts in the distributions of many bird species by 2070 , with as much as $57 \%$ of the state occupied by novel bird species assemblages. In contrast to other areas of California, however, Stralberg et al. (2009) predicted that bird species' ranges in the Sierra Nevada will largely shift upslope in concert with one another, generally maintaining current species assemblages. Other evidence suggests that distributions of many bird (Tingley et al. 2009, Tingley and Beissinger 2013) as well as mammal (Moritz et al. 2008) species in the Sierra Nevada have already shifted in response to climate change during the past century, with some species shifting their ranges upslope in response to temperature changes and others shifting their ranges downslope in response to precipitation changes (Tingley et al. 2012).

The Climate Change Vulnerability Index (CCVI) was developed by NatureServe (Young et al. 2011) to predict vulnerability of plant and animal species to forecasted climate change, using a standardized method that has been applied across numerous taxa and regions (e.g., Young et al. 2009, Dubois et al. 2011, Walk et al. 2011, Anacker et al. 2013). The CCVI employs a scoring system to assess species-specific exposure and sensitivity to climate change within a defined geographic area, through the integration of spatially explicit climate change projections and detailed information about the distribution, ecology, and life-history of focal species (Young et al. 2009, 2011, 2012).

To investigate the potential impact of climate change on breeding bird populations in the Sierra Nevada, we used the CCVI to assess vulnerability of 168 bird species that breed regularly during summer in the region. To assess potential variation in response to uncertain future climate scenarios, we conducted the assessment under two different climate models with substantially divergent projections about future precipitation in the Sierra Nevada. Our primary goals were to identify individual bird species whose Sierra Nevada breeding populations are most likely to be jeopardized by climate change during the next half-century, and to assess patterns in the habitat associations of those species. We stress that we did not attempt to assess the overall vulnerability of individual species to all possible threats, but rather the likely vulnerability of each species to climate change during the next 40-50 years. Additionally, other nonclimate factors, such as habitat destruction and urban encroachment, or small population size, could also be important in driving overall vulnerability. Our results therefore will need to be considered in concert with other nonclimate factors for establishing conservation priorities and formulating management strategies (Ohlemüller et al. 2008, Young et al. 2011, Gardali et al. 2012, Anacker et al. 2013).

\section{METHODS}

\section{Study area}

We defined the Sierra Nevada according to biogeographical boundaries for California ecoregions established in Hickman (1993) and Davis and Stoms (2012). The 6.3 million ha region includes the Sierra Nevada foothills and highlands, as well as the Tehachapi Mountains at the southern extreme of the region (Fig. 1). Approximately $37 \%$ of lands in the Sierra Nevada are privately owned, with private holdings heavily concentrated at lower elevations. The remaining lands are publicly owned and largely concentrated in national forests $(47 \%)$ and national parks $(10 \%)$.

\section{Assessing species vulnerability}

We selected 168 bird species that breed or occur regularly during summer in the Sierra Nevada (Appendix 1). Although > 300 bird species are known to occur within the region (Lukas 2011, Beedy and Pandolfino 2013), many of these species are present only in winter, during northbound or southbound migration, or as rare vagrants. We restricted our list to species that regularly breed in the region, based on recent published sources (e.g., Siegel and DeSante 1999, Lukas 2011, Beedy and Pandolfino 2013) as well as personal experience.

For each species, our CCVI assessments included (a) projections of direct exposure to future climate change based on fine-scale, spatially explicit climate change projections, (b) four factors that assess indirect exposure to climate change, (c) 15 factors that assess sensitivity to climate change, and (d) four factors that incorporate any previously documented or modeled responses to 
Table 1. Vulnerability factors that contribute to the Climate Change Vulnerability Index (Young et al. 2011), and the number of bird species breeding in the Sierra Nevada (out of 168 we considered) that we assigned to each vulnerability score for each factor. Note that some scores were not used for certain vulnerability factors (e.g., "Greatly Increase" was not used for factor B3).

\begin{tabular}{|c|c|c|c|c|c|c|c|}
\hline \multirow[b]{2}{*}{ Climate Change Vulnerability Factor } & \multicolumn{7}{|c|}{ No. of species receiving each score for indicated vulnerability factor ${ }^{\dagger}$} \\
\hline & GI & $\mathrm{I}$ & SI & $\mathrm{N}$ & SD & $\mathrm{D}$ & $\mathrm{U}$ \\
\hline \multicolumn{8}{|l|}{ Section A - Direct Exposure to Climate Change } \\
\hline A - Projected exposure to future climate change & \multicolumn{7}{|c|}{$\mathrm{n} / \mathrm{a}-$ Entries for this factor are quantitative rather than categorical } \\
\hline \multicolumn{8}{|l|}{ Section B - Indirect Exposure to Climate Change } \\
\hline B1 - Exposure to sea-level rise & 0 & 0 & 0 & 168 & 0 & 0 & 0 \\
\hline $\begin{array}{l}\text { B2a - Ability to disperse through foreign habitats or } \\
\text { barriers }\end{array}$ & 0 & 2 & 22 & 144 & $\mathrm{n} / \mathrm{a}$ & $\mathrm{n} / \mathrm{a}$ & 0 \\
\hline $\begin{array}{l}\text { B2b - Ability to disperse across anthropogenic } \\
\text { barriers }\end{array}$ & 0 & 0 & 0 & 168 & $\mathrm{n} / \mathrm{a}$ & $\mathrm{n} / \mathrm{a}$ & 0 \\
\hline $\begin{array}{l}\text { B3 - Impact of climate-related human activities (e. } \\
\text { g., windfarms, dams) }\end{array}$ & $\mathrm{n} / \mathrm{a}$ & 0 & 29 & 136 & 3 & 0 & 0 \\
\hline \multicolumn{8}{|l|}{ Section C - Sensitivity to Climate Change } \\
\hline $\begin{array}{l}\mathrm{C} 1 \text { - Ability to disperse in response to climate } \\
\text { change }\end{array}$ & 0 & 0 & 1 & 167 & 0 & 0 & 0 \\
\hline $\mathrm{C} 2 \mathrm{ai}-$ Historic temperature variation & 0 & 0 & 9 & 158 & 0 & $\mathrm{n} / \mathrm{a}$ & 0 \\
\hline C2aii - Physiological need for cool temperatures & 4 & 6 & 7 & 126 & 25 & $\mathrm{n} / \mathrm{a}$ & 0 \\
\hline $\mathrm{C} 2$ bi - Past precipitation variation & 0 & 0 & 2 & 25 & 141 & $\mathrm{n} / \mathrm{a}$ & 0 \\
\hline $\begin{array}{l}\text { C2bii - Physiological or ecological need for moist } \\
\text { habitats }\end{array}$ & 6 & 16 & 18 & 114 & 14 & $\mathrm{n} / \mathrm{a}$ & 0 \\
\hline $\begin{array}{l}\mathrm{C} 2 \mathrm{c}-\text { Response to increased disturbance regimes (e. } \\
\text { g., fires, floods) }\end{array}$ & $\mathrm{n} / \mathrm{a}$ & 3 & 29 & 19 & 51 & 10 & 56 \\
\hline C2d - Response to decreased ice and snow & $\mathrm{n} / \mathrm{a}$ & 1 & 1 & 166 & $\mathrm{n} / \mathrm{a}$ & $\mathrm{n} / \mathrm{a}$ & 0 \\
\hline C3 - Dependence on uncommon geologic features & $\mathrm{n} / \mathrm{a}$ & 0 & 12 & 4 & 141 & 11 & 0 \\
\hline $\begin{array}{l}\text { C4a - Dependence on particular plant or animal } \\
\text { species }\end{array}$ & 0 & 0 & 5 & 163 & $\mathrm{n} / \mathrm{a}$ & $\mathrm{n} / \mathrm{a}$ & 0 \\
\hline $\begin{array}{l}\mathrm{C} 4 \mathrm{~b}-\text { Dietary versatility; reliance on } 1 \text { or } 2 \text { species } \\
\text { for food }\end{array}$ & $\mathrm{n} / \mathrm{a}$ & 8 & 18 & 133 & 9 & $\mathrm{n} / \mathrm{a}$ & 0 \\
\hline C4d - Dependence on other species to disperse & $\mathrm{n} / \mathrm{a}$ & 0 & 0 & 168 & $\mathrm{n} / \mathrm{a}$ & $\mathrm{n} / \mathrm{a}$ & 0 \\
\hline $\mathrm{C} 4 \mathrm{e}-$ Reliance on interspecific interactions & $\mathrm{n} / \mathrm{a}$ & 0 & 0 & 168 & $\mathrm{n} / \mathrm{a}$ & $\mathrm{n} / \mathrm{a}$ & 0 \\
\hline $\mathrm{C} 5 \mathrm{a}-$ Degree of measured genetic variation & 0 & 0 & 2 & 5 & 0 & $\mathrm{n} / \mathrm{a}$ & 161 \\
\hline $\begin{array}{l}\mathrm{C} 5 \mathrm{~b} \text { - Indication of bottlenecks in recent } \\
\text { evolutionary history }\end{array}$ & $\mathrm{n} / \mathrm{a}$ & 3 & 3 & 162 & $\mathrm{n} / \mathrm{a}$ & $\mathrm{n} / \mathrm{a}$ & 0 \\
\hline $\begin{array}{l}\text { C6 - Vulnerability based on phenotypic inability to } \\
\text { respond }\end{array}$ & $\mathrm{n} / \mathrm{a}$ & 0 & 0 & 168 & 0 & $\mathrm{n} / \mathrm{a}$ & 0 \\
\hline \multicolumn{8}{|l|}{$\begin{array}{l}\text { Section D - Documented Response to Climate } \\
\text { Change }\end{array}$} \\
\hline $\begin{array}{l}\text { D1 - Documented range changes due to recent } \\
\text { climate change }\end{array}$ & 0 & 1 & 26 & 32 & 24 & 0 & 85 \\
\hline $\begin{array}{l}\text { D2 - Modeled predictions for range contraction or } \\
\text { expansion }\end{array}$ & 1 & 12 & 47 & 52 & 41 & 13 & 2 \\
\hline $\begin{array}{l}\text { D3 - Overlap of modeled future range with current } \\
\text { range }\end{array}$ & 0 & 14 & 38 & 110 & $\mathrm{n} / \mathrm{a}$ & $\mathrm{n} / \mathrm{a}$ & 6 \\
\hline $\begin{array}{l}\text { D4-Overlap of predicted future range with } \\
\text { protected areas }\end{array}$ & $\mathrm{n} / \mathrm{a}$ & 61 & 95 & 7 & $\mathrm{n} / \mathrm{a}$ & $\mathrm{n} / \mathrm{a}$ & 5 \\
\hline
\end{tabular}

${ }^{\top} \mathrm{GI}=$ greatly increased vulnerability, I=increased vulnerability, SI=somewhat increased vulnerability, $\mathrm{N}=$ neutral, $\mathrm{SD}=$ somewhat decreased vulnerability, $\mathrm{D}=$ decreased vulnerability, $\mathrm{U}=\mathrm{Unknown}$.

climate change (Table 1). For sections (b) through (d), each factor was scored to one of five categories or "unknown," based on how the factor may be expected to increase or decrease vulnerability to climate change (Table 2). Ordinal scores for each factor were determined based on published and unpublished information about the species in the assessment area. Space limitations preclude citing sources of information on natural history, ecology, and potential sensitivity to climate change for 168 species, but many of the works we consulted are provided in Poole (2005), Shuford and Gardali (2008), and Steel et al. (2012). We also relied on Jongsomjit et al. (2011) for scoring vulnerability based on modeled responses to climate change, and Tingley et al. (2012) 
for scoring vulnerability based on documented responses to climate change. Additional details about the data sets used, and our rationale for scoring the various factors are provided in Appendix 2.

Fig. 1. The Sierra Nevada regional boundaries delineating our climate change vulnerability assessment area for breeding bird species.

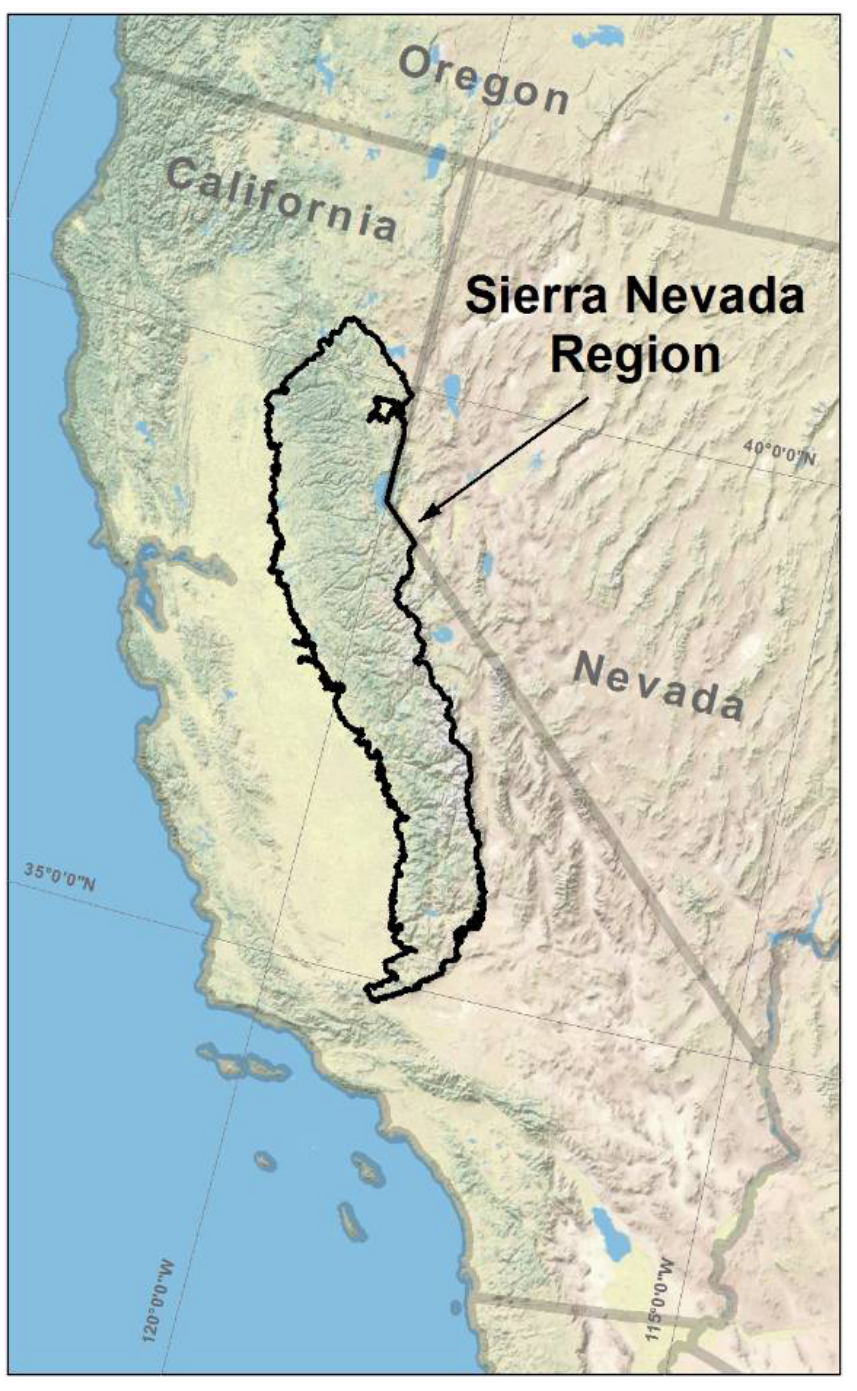

For section (a), we indexed exposure to projected climate change as the proportion of each species' current range within the Sierra Nevada, forecast to undergo different magnitudes of temperature and moisture change by the period 2040-2069. The CCVI guidelines (Young et al. 2011) recommend using the most accurate broad-scale range map polygons rather than finer point-scale range maps. We used broad-scale range maps of bird species' breeding or summer ranges in California developed by Zeiner et al. (1990) and then digitized and for some species later updated by staff at the California Department of Fish and Game.
Table 2. Categorical vulnerability rankings produced by NatureServe's Climate Change Vulnerability Index (Young et al. 2011).

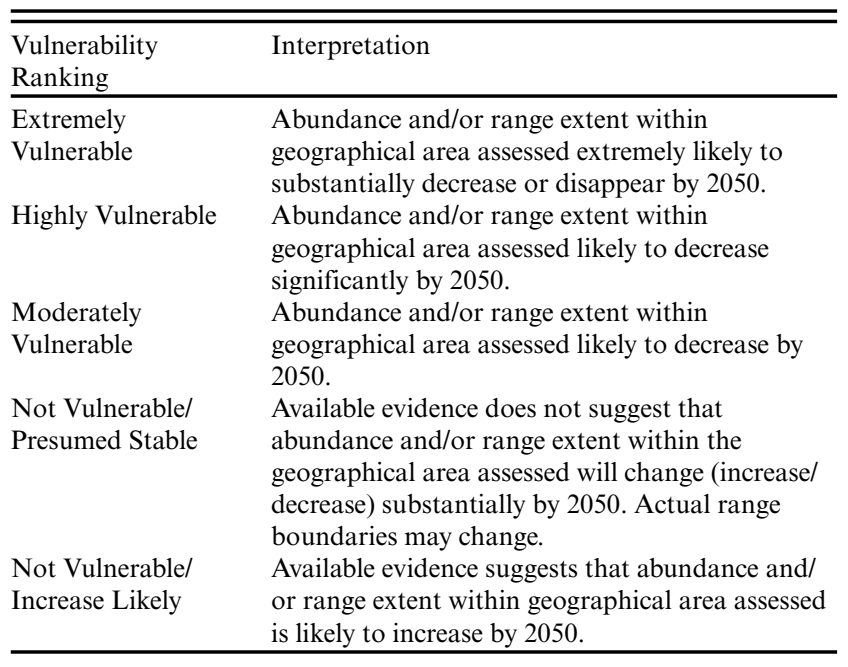

To assess climate change vulnerability factors related to current and projected climatic conditions, we used historical and projected future temperature, precipitation, and related environmental moisture metrics that were produced for California at a 270-meter grid-scale (Thorne et al. 2012) and clipped to the particular mapped breeding range of each species in the Sierra Nevada. These monthly climate data were developed using the Basin Characterization Model (BCM; Flint and Flint 2007), which uses a unique statistical downscaling technique that regresses historical trend on a per-grid cell basis, and accounts for the effects of topographic complexity to better approximate climatic conditions at a fine spatial resolution (Flint and Flint 2012). The climate data are then used in BCM on a per-grid cell basis to project climatic water deficit (CWD), a measure of unmet water demand by plants for metabolic purposes (Stephenson 1998), snowpack, runoff, and recharge. These outputs are from a mechanistic model, meaning they are derived from site characteristics (depth of soil and permeability of bedrock) as well as temperature and precipitation. The model has been calibrated through the use of 159 stream gauges in California (Flint et al. 2013). We used 30-year blocks to derive characteristic means of the values used: monthly mean temperature, precipitation, and climatic water deficit, for historic and future time periods (Thorne et al. 2012). We used the difference between recent historical values (from 1971-2000) and projections for 2040-2069 for our projections of climate change exposure (Figs. 2 and 3). Following CCVI guidelines (Young et al. 2011), we assessed projected changes in temperature directly, whereas for moisture we used projected changes in climatic water deficit (CWD). Although Young et al. (2011) provide explicit guidelines for using the Hamon ratio of actual evapotranspiration to potential evapotranspiration (Hamon 1961) as a moisture metric that is available for the entire United States (Hamon 1961), they caution that the metric is not ideal because it does not include components of habitat moisture retention such as water holding capacity, effect of snow pack on water availability, and different vegetation 
types, all of which are challenging to incorporate at a national scale. The authors therefore explicitly encourage the use of more detailed, locally-relevant models of moisture availability if they are available. We used climatic water deficit, the annual plant evaporative demand that exceeds available soil water, and integrates precipitation and temperature inputs to yield a single moisture index that can increase through increased evaporative demand, decreased water availability, or both factors (Thorne et al. 2012). CWD provides an ecologically meaningful index of available moisture and is increasingly used for predicting the effects of climate change on ecosystems (e.g., Crimmins et al. 2011), including Sierra Nevada ecosystems (van Mantgem and Stephenson 2007, Lutz et al. 2010). Using this alternative metric required that we develop a new set of threshold values for scoring species' predicted exposure to changes in moisture across their ranges in the Sierra Nevada. Following the methods that Young et al. (2011) used in setting national threshold values for the Hamon Index, we used one and two positive and negative standard deviations from the mean projected CWD across the Sierra Nevada as our threshold values.

To capture uncertainty inherent in climate projections, we selected two models, the Geophysical Fluid Dynamics Laboratory (GFDL; Delworth et al. 2006, Stouffer et al. 2006) and Parallel Climate Model (PCM; Washington et al. 2000, Meehl et al. 2003), that accurately represent California climate in current time and provide divergent future projections whose implications for California's climate have been well explored (Cayan et al. 2008). For both models we based future climate projections (Figs. 2 and 3) on a medium-high (A2) emissions scenario, resulting in medium-high global temperature increases (Hayhoe et al. 2004). Both models project warmer future temperatures but the GFDL model projects moisture deficit to be more pronounced in the Sierra Nevada than does the PCM model; e.g., GFDL shows substantial drying over the coming decades, whereas PCM projects relatively unchanged average precipitation (Thorne et al. 2012).

The CCVI also requires assessments of species' sensitivity to changes in temperature and precipitation based on exposure to past climatic variation (Young et al. 2011). We quantified variation in temperature and precipitation across the Sierra Nevada Region between 1971 and 2000 (Fig. 4), and calculated the amount of variation within each species' breeding range in the region. Calculations were based on year-round variation, even for migratory species not present year round in the Sierra Nevada, because habitats and food resources used by breeding birds are subject to year-round temperature variation (Young et al. 2011). To describe current temperature variation, we used the average annual difference between monthly mean July maximum temperatures and monthly mean January minimum temperatures within each 270-m grid cell, and for precipitation, the difference between the highest and lowest annual precipitation $(\mathrm{mm})$ values for each cell during the 30-year period. Exposure to temporal variability in climate may not be an ideal proxy for sensitivity to climate change because some species may be able to tolerate wider variation in climatic conditions than they have experienced in the area and time span under consideration, but this approach nevertheless provides a standard that facilitates interstudy comparisons.
Fig. 2. Differences between current and future temperature based on Geophysical Fluid Dynamics Laboratory (GFDL) and Parallel Climate Model (PCM) climate models within the Sierra Nevada. For each 270-m grid cell, monthly mean temperature was calculated as mean of the monthly maximum temperature + the monthly minimum temperature divided by two during historical (1971-2000) and future (2040-2069) 30year periods. The maps represent the differences between the values from the two 30 -year periods. The GFDL model projects greater warming than does the PCM model, but under both models more warming is generally anticipated in higher elevation and eastern sections than in lower elevation and western sections of the Sierra Nevada.

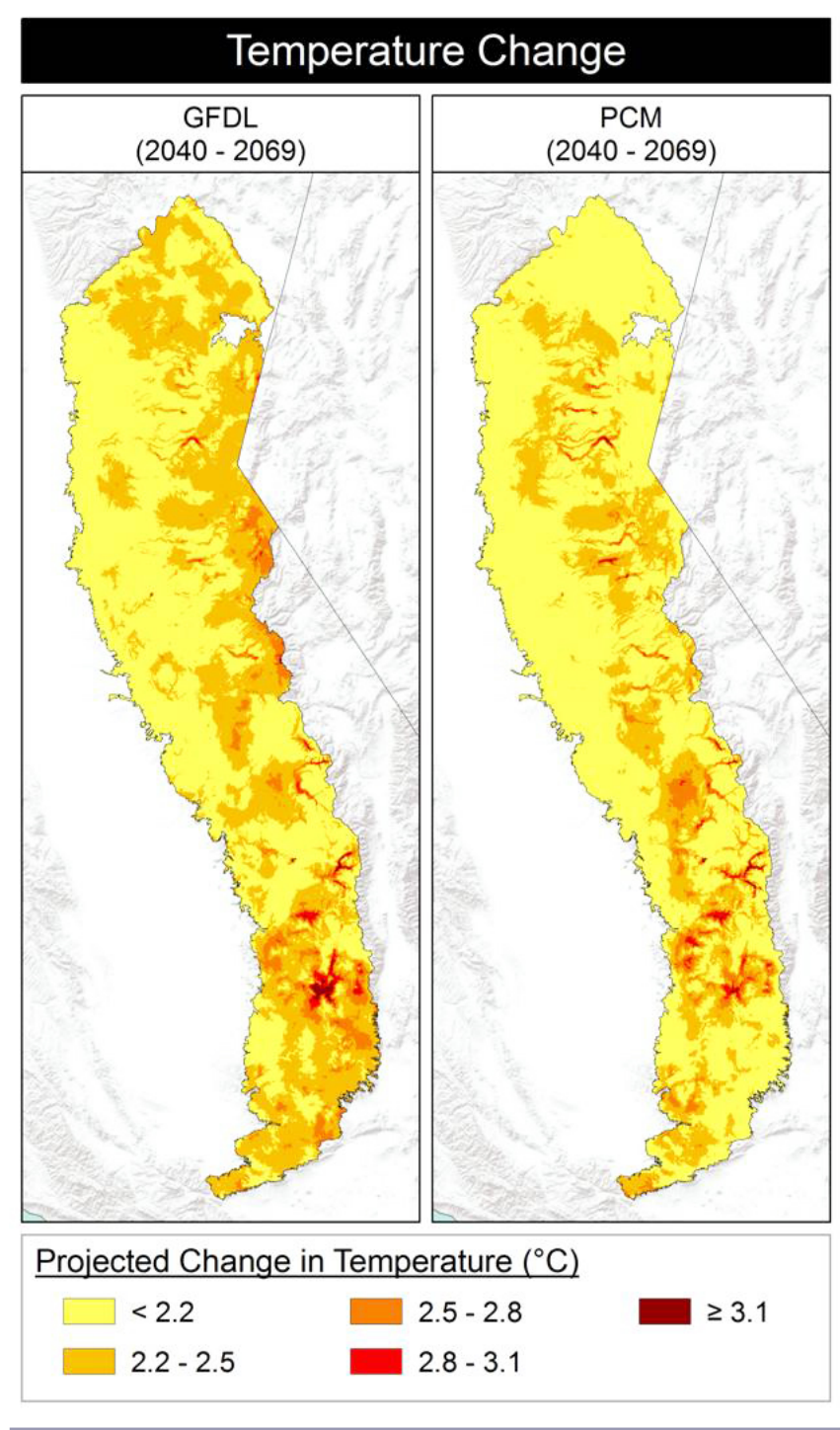

For calculating final vulnerability rankings, we used CCVI version 2.3. Young et al. $(2011,2012)$ provide detailed descriptions of the factor weighting scheme and the algorithm for calculation of the final vulnerability score. In brief, the index first combines 
Fig. 3. Differences between current and future moisture, quantified here as climatic water deficit (CWD), based on Geophysical Fluid Dynamics Laboratory (GFDL) and Parallel Climate Model (PCM) climate models within the Sierra Nevada. For each 270-m grid cell, monthly mean CWD evapotranspiration values were calculated as mean of the annual CWD values during historical (1971-2000) and future (2040-2069) 30-year periods. Greater changes in CWD values represent drier future conditions. The maps represent the differences between the CWD values from the two 30-year periods for each climate model. The GFDL model projects much more drying than does the PCM model, but more drying is anticipated in higher elevation and eastern sections than in lower elevation and western sections of the Sierra Nevada under both models.

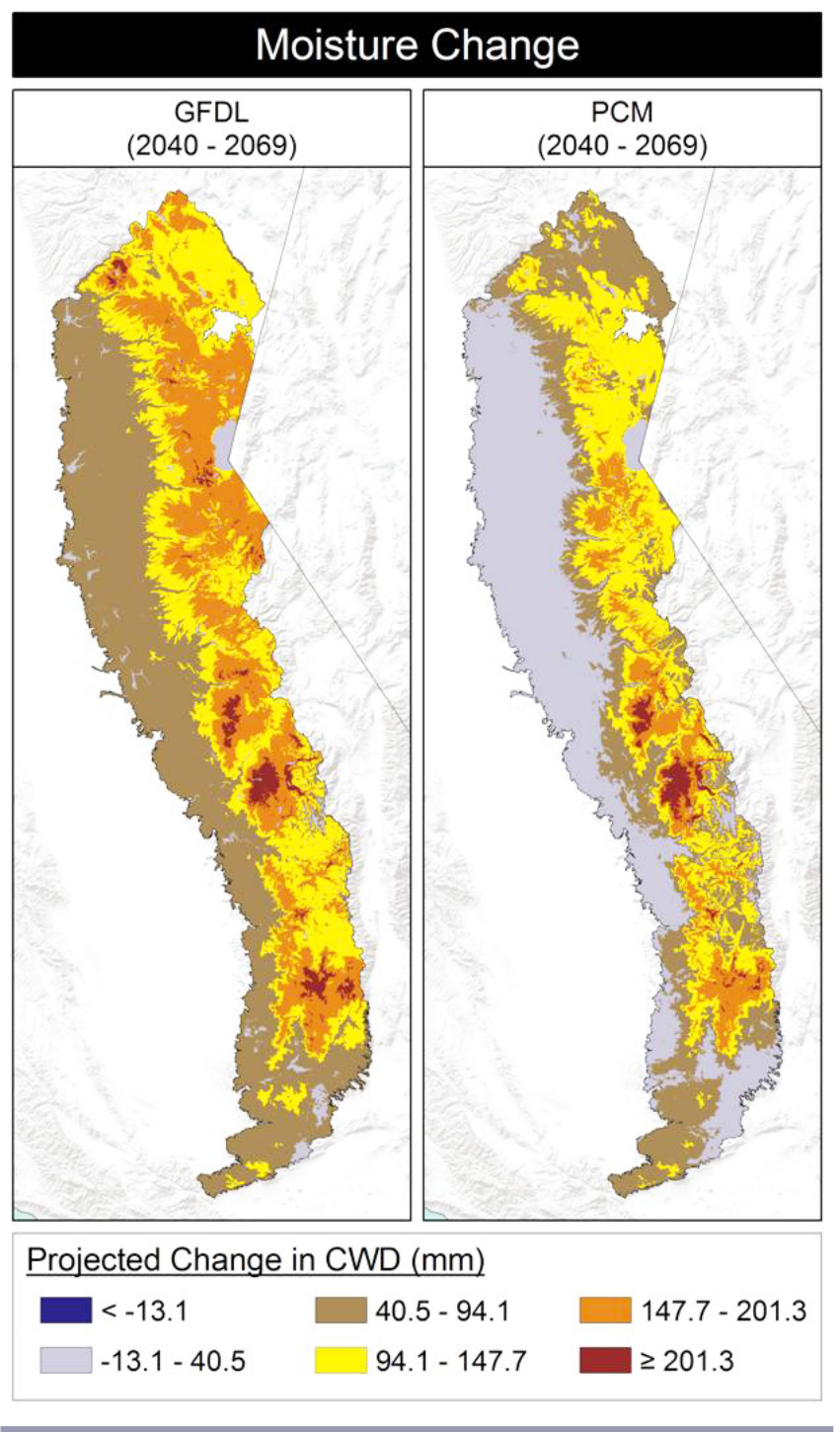

information on exposure and sensitivity by summing subscores for each of the four indirect exposure and 15 species sensitivity factors (Sections B and C in Table 1), which receive values (3.0,
Fig. 4. Recent historical (1971-2000) variation in (a) temperature and (b) precipitation within the Sierra Nevada. For temperature, bins represent the average annual difference between monthly mean July maximum temperatures and monthly mean January minimum temperatures within each 270-m grid cell. Moisture is represented as the difference between the highest and lowest annual precipitation ( $\mathrm{mm}$ ) values for each cell during the 30 -year period. Lowland areas of the Sierra Nevada are generally exposed to greater annual temperature variation than high-elevation areas, and northern areas are generally exposed to greater annual variation in precipitation than southern areas.

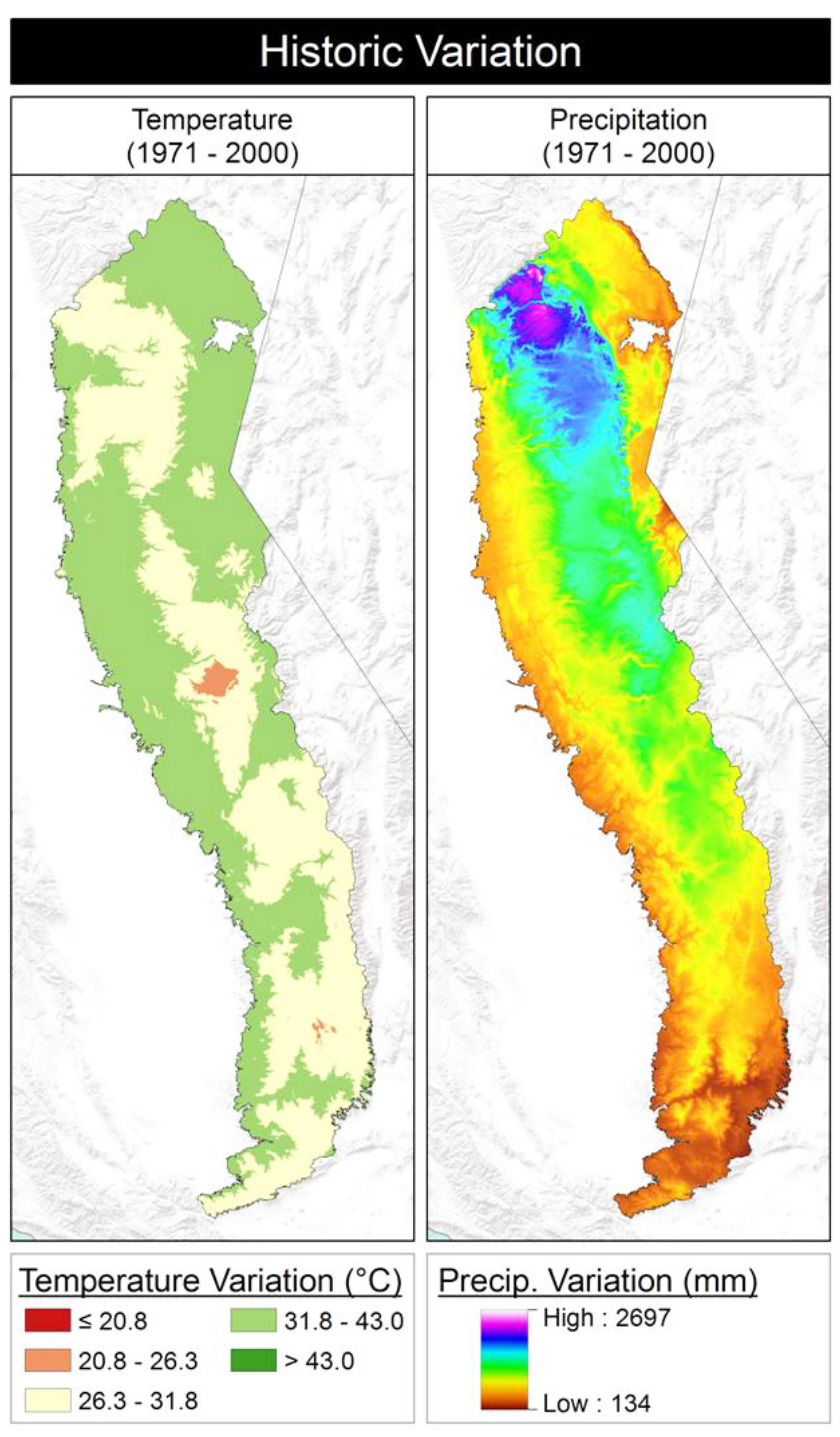

$2.0,1.0,0,-1.0$, and -2.0$)$ that reflect the degree to which vulnerability is increased or decreased. The individual factor values are then weighted by exposure (Section A, Table 1) to calculate a subscore for exposure and sensitivity. For most factors, the exposure weighting is the product of weightings for temperature $(0.5,1.0,1.5$, or 2.0 , depending on the projected 
temperature increase) and climatic water deficit $(0.5,1.0,1.5$, or 2.0, depending on the projected change in climatic water deficit). The thresholds for the index scores of Extremely Vulnerable, Highly Vulnerable, Moderately Vulnerable, Not Vulnerable/ Presumed Stable, and Not Vulnerable/Increase Likely are 10.0, 7.0, 4.0, and -2.0, and correspond with possible scenarios of exposure and sensitivity. For example, the Extremely Vulnerable threshold is reached for species with high exposure and at least two indirect exposure or sensitivity factors with scores of 3.0, or with high exposure and three factors with scores of 2.0. The four vulnerability factors for the documented and/or modeled response subscore (Section D, Table 1) are scored in the same manner as the exposure and sensitivity factors, but are summed independently with no weighting, because exposure has presumably already been incorporated in the studies upon which the factors are based. The thresholds for these index scores are $6.0,4.0,2.0$, and -1.0 , a schema that accounts for the smaller number of response factors than are incorporated in the exposure and sensitivity subscore. The two subscores are averaged to yield the overall index of climate change vulnerability.

\section{Identifying habitats that host the most vulnerable species}

To identify major habitats in the Sierra Nevada that support the most vulnerable species, we assigned each species up to three of six habitat classifications we developed to capture the diversity of Sierra Nevada birds' habitat associations with a minimal number of categories: foothill woodlands and foothill chaparral; montane conifer forest; montane chaparral and sagebrush; aquatic habitats including rivers, ponds, and lakes; marshes, meadows, and riparian vegetation; and high-elevation regions encompassing the subalpine and alpine zones. Classifications were based on published literature (e.g., Grinnell and Miller 1944, Beedy and Granholm 1985, Gaines 1992, Lukas 2011) as well as our own extensive experience in the region. We then assessed habitat associations in relation to CCVI rankings using a proportional odds ordinal logistic regression model (McCullagh 1980). This regression model interprets an ordinal response variable as an ordered series of binary logistic regressions with common regression parameters. A full model (i.e., all habitat and range variables) was run on both the GFDL and PCM CCVI rankings (ordinally ranked 1 for Increase Likely, 2 for Presumed Stable, 3 for Moderately Vulnerable, 4 for Highly Vulnerable, and 5 for Extremely Vulnerable), with the importance of habitat associations assessed by Wald $\mathrm{Z}$ statistics. Models were fit using maximum likelihood estimation. All analyses were run in $\mathrm{R}$ version 2.15.1 using the package 'rms' (Harrell 2012).

\section{RESULTS}

\section{Individual climate change vulnerability factors}

Our entire matrix of climate change vulnerability factor scores for all 168 species is provided in Appendix 3. Individual climate change vulnerability factors varied widely in the degree to which they differentiated risk among the species we assessed (Table 1). Projections of direct exposure to climate change varied substantially across species, with many species falling into one of several broad groupings. Species that breed primarily at low elevations on the Sierra Nevada's west slope, e.g., California Thrasher, (Toxostoma redivivum; Fig. 5) have generally experienced relatively high temperature variation but low precipitation variation in the recent past, and are projected to be relatively less exposed, compared with other parts of the Sierra Nevada, to climate change in the next 50 years. Species that breed primarily on the east slope, e.g., Brewer's Sparrow, (Spizella breweri; Fig. 6) have generally experienced relatively high temperature and precipitation variation in the recent past, and are projected to experience intermediate to high climate change exposure compared to other portions of the Sierra Nevada. Species restricted to breeding in alpine/subalpine areas, e.g., Graycrowned Rosy-Finch, (Leucosticte tephrocotis; Fig. 7) have generally experienced intermediate temperature and precipitation variation in the recent past, and are projected to be exposed to high levels of climate change. Last, species with widespread breeding distributions across the low- and mid-elevation portions of the Sierra Nevada, e.g., Song Sparrow, (Melospiza melodia; Fig. 8) experienced intermediate (relative to the entire region) climate variation in the recent past and are projected to be exposed to intermediate levels of climate change in the coming decades.

Unlike direct exposure to climate change, vulnerability factors associated with indirect exposure to climate change (Table 1, Section B) did not vary greatly among species in our assessment. The 15 vulnerability factors associated with sensitivity to climate change (Table 1, Section C) collectively yielded substantially more variation across species, with especially diverse effects indicated for physiological or ecological need for moist habitats (factor C2bii) and responses to increased disturbance regimes (factor C2c). Vulnerability factors associated with documented responses to climate change (Table 1, Section D) yielded diverse scores across species for all four vulnerability factors.

\section{Identifying the most vulnerable species}

Of the five vulnerability rankings that the CCVI assigns, only one species, White-tailed Ptarmigan (Lagopus leucura), received the most vulnerable ranking, Extremely Vulnerable (Appendix 1); this ranking resulted using projections from both climate models. No species received the second-highest vulnerability ranking, Highly Vulnerable, using projections from either climate model. Sixteen species (Table 3) ranked as Moderately Vulnerable under at least one of the two climate scenarios (15 species using GFDL-based climate projections and 13 using PCM-based climate projections). The remaining 151 species were scored as Presumed Stable (110 species using GFDL-based projections and 125 using PCM-based projections), and Increase Likely (41 species using GFDL-based projections and 29 using PCM-based projections [Appendix 1]).

\section{Variation in vulnerability rankings based on different climate models}

Climate projections based on the GFDL climate model yielded fewer species ranked as Presumed Stable (110 species) than did projections based on the PCM model (125 species). The GFDL climate projections yielded more species ranked as Extremely Vulnerable or Moderately Vulnerable than did the PCM climate projections (16 species under the GFDL climate model versus 14 species under the PCM climate model), but also yielded more species ranked as Increase Likely (42 species versus under the GFDL model versus 29 species under the PCM model; Table 4). 
Fig. 5. Exposure of California Thrasher (Toxostoma redivivum) to recent temperature variation (a) and recent precipitation variation (d) within its mapped breeding range in the Sierra Nevada, based on climate data from the 30-year period 1971-2000, and projected change in temperature (b and c) and climatic water deficit (CWD; e and f) between the 30-year periods 1971-2000 and 2040-2069, based on the Geophysical Fluid Dynamics Laboratory (GFDL) and Parallel Climate Model (PCM) climate models and the A2 (medium-high) emissions scenario. In the portion of the Sierra Nevada in which California Thrasher currently breeds, historic exposure to temperature variation was relatively high, historic exposure to precipitation variation was relatively low, and projected changes in temperature and moisture are relatively low compared to other portions of the Sierra Nevada.

\section{California Thrasher (Toxostoma redivivum)}

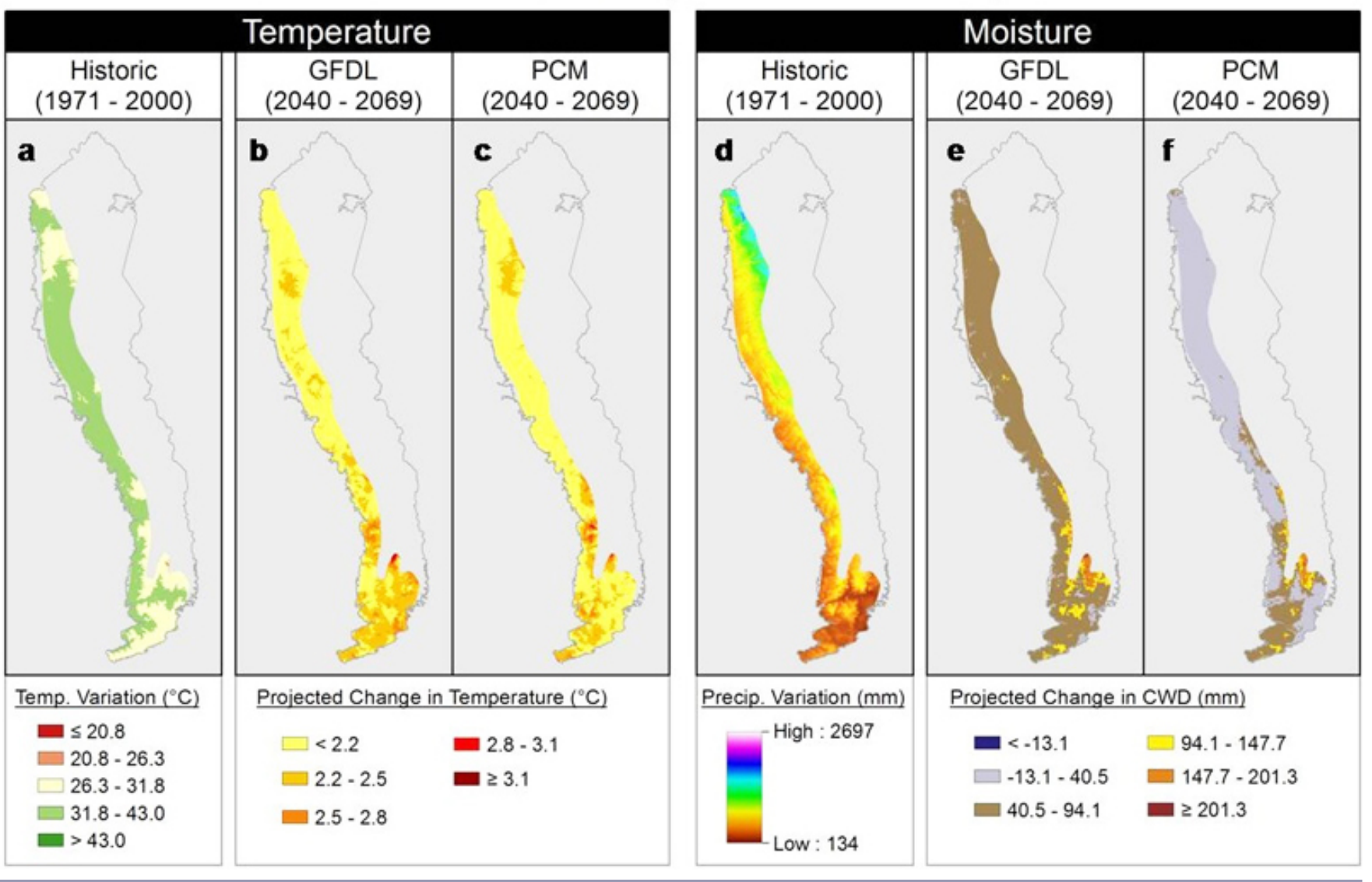

Three species received more vulnerable rankings using climate projections from the GFDL model than from the PCM model, whereas 13 received more vulnerable rankings using projections from the PCM climate model than from the GFDL model (Appendix 1). The three species showing more vulnerable rankings with GFDL projections included two, Osprey (Pandion haliaetus) and American Dipper (Cinclus mexicanus), associated with aquatic habitats and one, Prairie Falcon (Falco mexicanus) associated with sagebrush or montane chaparral. All three of these species ranked as Moderately Vulnerable using GFDLbased climate projections and Presumed Stable using PCM projections. The 13 species receiving more vulnerable rankings under the PCM projections included 11 species associated with foothill woodland and chaparral (five species with this classification alone and six species with this and one other habitat classification), one species, Black-billed Magpie (Pica hudsonia), associated with montane chaparral and sagebrush and with marsh, meadow, and riparian habitats, and one species, Clark's Nutcracker (Nucifraga columbiana) associated with both montane conifer forest and alpine/subalpine habitats. Twelve of these 13 species ranked Increase Likely with GFDL projections and Presumed Stable with PCM projections whereas one, Clark's Nutcracker, ranked as Presumed Stable with GFDL projections and Moderately Vulnerable with PCM projections.

\section{Importance of habitat associations}

Many species (109) were assigned just one primary habitat classification but two or three classifications were assigned to 59 species that occur extensively in multiple habitats or are associated with ecotones (Appendix 1). Among the 17 species ranked as moderately or extremely vulnerable under projections using at least one of the two climate models, seven species were associated with montane conifer forest, five with aquatic habitats, four with alpine/subalpine habitats, three with marsh, meadow, or riparian 
Fig. 6. Exposure of Brewer's Sparrow (Spizella breweri) to recent temperature variation (a) and recent precipitation variation (d) within its mapped breeding range in the Sierra Nevada, based on climate data from the 30-year period 1971-2000, and projected change in temperature ( $\mathrm{b}$ and c) and climatic water deficit (CWD; e and f) between the 30-year periods 1971-2000 and 2040-2069 based on the Geophysical Fluid Dynamics Laboratory (GFDL) and Parallel Climate Model (PCM) climate models and the A2 (medium-high) emissions scenario. In the portion of the Sierra Nevada in which Brewer's Sparrow breeds, historic exposure to temperature and precipitation variation was relatively high, and projected changes in temperature and moisture are intermediate to high compared to other portions of the Sierra Nevada.

\section{Brewer's Sparrow (Spizella breweri)}

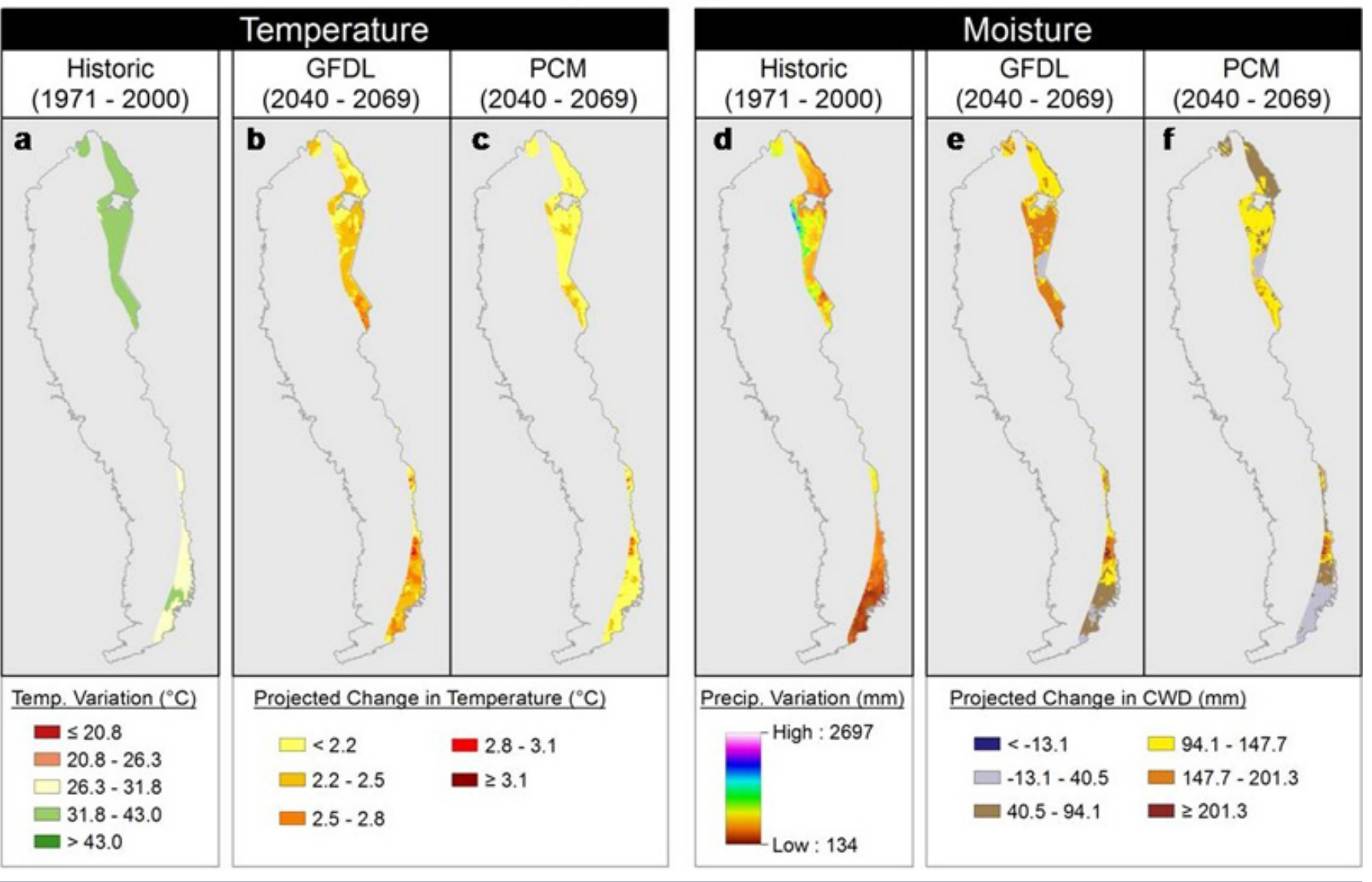

vegetation, one with sagebrush or montane chaparral, and none with foothill habitats (Table 3). Species associated with alpine/ subalpine habitats were ranked significantly more vulnerable to climate change than species of other habitats, using projections based on both the GFDL $(\mathrm{P}=0.049)$ and PCM $(\mathrm{P}=0.007)$ climate models (Table 4). Species associated with aquatic habitats were also ranked as more vulnerable than species of other habitats, but this difference was significant only using rankings based on the GFDL climate model $(\mathrm{P}=0.049 ; \mathrm{P}=0.380$ for the $\mathrm{PCM}$ model $)$. Species associated with foothill woodland and foothill chaparral, and with montane chaparral and sagebrush, were ranked as significantly less vulnerable than species of other habitat classifications using projections from both climate models (Foothill: $\mathrm{P}<0.001$ for GFDL, $\mathrm{P}=0.007$ for PCM; Montane: $\mathrm{P}$ $=0.026$ for GFDL, $\mathrm{P}=0.008$ for $\mathrm{PCM}$ ). Indeed, these species frequently scored as Increase Likely indicating that their ranges or populations within the Sierra Nevada could expand because of climate change. Species associated with marshes, meadows, and riparian vegetation were also ranked as less vulnerable than those of other habitats, a difference that was significant using projections based on the PCM model $(\mathrm{P}=0.030)$ but marginal using the GFDL model projections $(\mathrm{P}=0.050)$ projections.

\section{DISCUSSION}

The majority of species $(65.5 \%$ using GFDL projections and $74.4 \%$ using PCM projections) are not projected to be jeopardized substantially or benefited by climate change in the region during the next 50 years; a moderate proportion of species $(24.4 \%$ using GFDL projections and $17.3 \%$ using PCM projections) are projected to experience increases in range or population within the region because of climate change; and a minority of species (9.5\% using GFDL projections and 8.3\% using PCM projections) are ranked as moderately or extremely vulnerable to climate change. The relatively low percentage of species with vulnerable 
Fig. 7. Exposure of Gray-crowned Rosy-Finch (Leucosticte tephrocotis) to recent temperature variation (a) and recent precipitation variation (d) within its mapped breeding range in the Sierra Nevada, based on climate data from the 30-year period 1971-2000, and projected change in temperature (b and c) and climatic water deficit (CWD; e and f) between the 30-year periods 1971-2000 and 2040-2069 based on the Geophysical Fluid Dynamics Laboratory (GFDL) and Parallel Climate Model (PCM) climate models and the A2 (medium-high) emissions scenario. In the portion of the Sierra Nevada in which Gray-crowned Rosy-Finch breeds, historic exposure to temperature and precipitation variation was intermediate, and projected changes in temperature and moisture are relatively high compared to other portions of the Sierra Nevada.

\section{Gray-crowned Rosy-Finch (Leucosticte tephrocotis)}
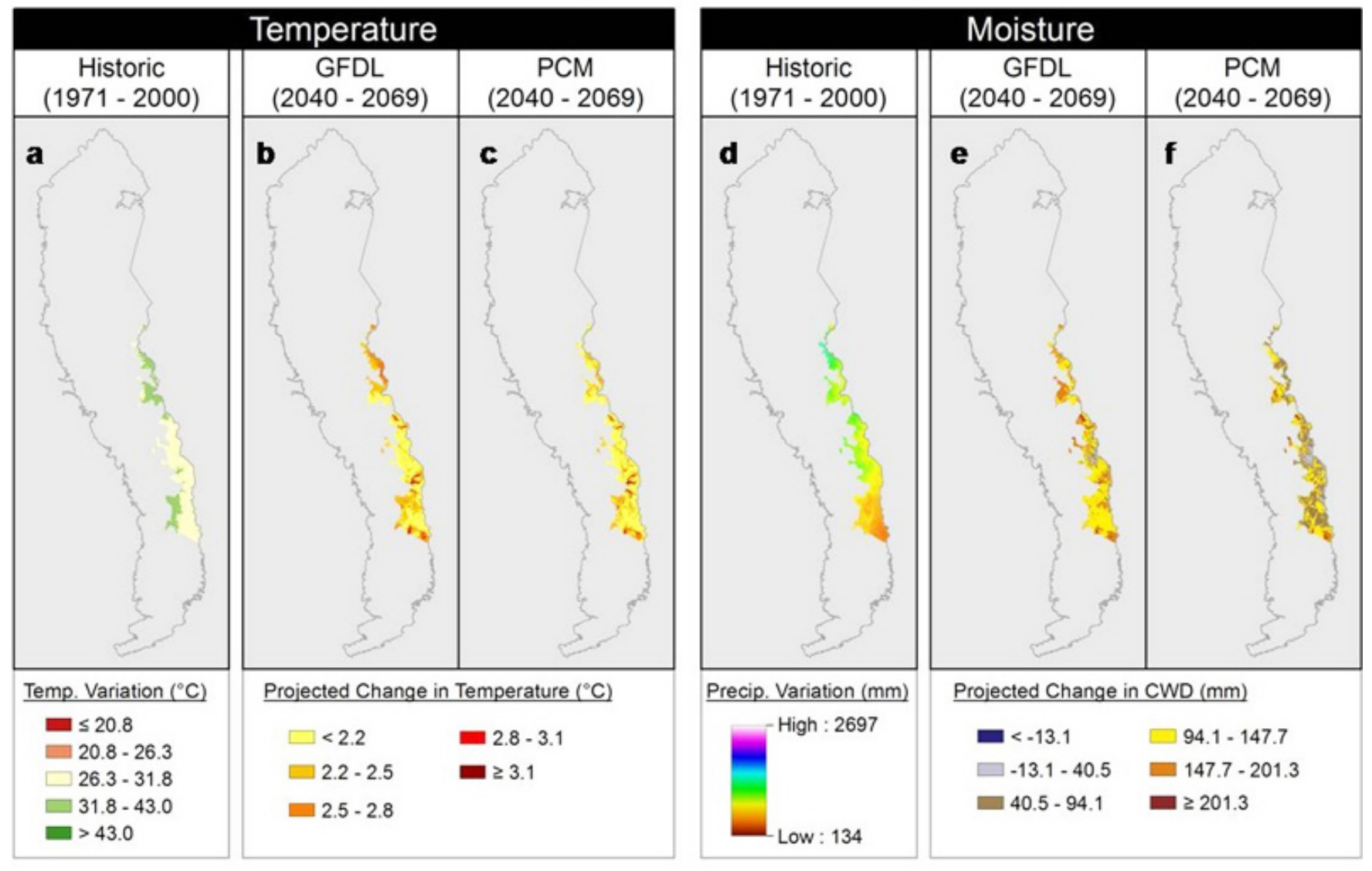

rankings is commensurate with other findings for bird species using the CCVI (Young et al. 2009, Dubois et al. 2011, Walk et al. 2011). Relative to other taxa, birds tend not to score as especially vulnerable because of their vagility and dispersal capacity, which may enhance their ability to shift their ranges in concert with appropriate environmental conditions as those conditions change and shift across the landscape. Nevertheless, the 17 species that our analysis identified as Extremely Vulnerable or Moderately Vulnerable (Table 3) should be considered in conservation planning efforts throughout the region.

\section{Importance of habitat associations}

Our analysis provided insight into which Sierra Nevada habitats host relatively more vulnerable bird species. Birds associated with alpine/subalpine and aquatic habitats ranked more vulnerable to climate change than birds associated with other habitats. In contrast, species of foothill, sagebrush, and chaparral habitats were ranked significantly less vulnerable to climate change.
Vulnerable alpine and subalpine species include White-tailed Ptarmigan, Clark's Nutcracker, American Pipit (Anthus rubescens), and Gray-crowned Rosy-Finch. Species restricted to alpine/subalpine zones may be particularly vulnerable to climate change because they lack higher altitude habitats to which they can shift their ranges (Loarie et al. 2009). Moreover, potentially important climate-related changes in the structure of subalpine forests have already been detected in the Sierra Nevada (Millar et al. 2004, Thorne et al. 2008, Dolanc et al. 2013). However, it should not be assumed that climate change will uniformly shift bird species' ranges upslope in response to increasing temperatures. Tingley et al. (2012) showed that avian range shifts during the past century occurred in response to changes in both temperature and precipitation, with changes in temperature clearly exerting upslope pressure on ranges, but changes in precipitation frequently exerting downslope pressure, and many species shifting their ranges downslope in response. 
Fig. 8. Exposure of Song Sparrow (Melospiza melodia) to recent temperature variation (a) and recent precipitation variation (d) within its mapped breeding range in the Sierra Nevada, based on climate data from the 30-year period 1971-2000, and projected change in temperature ( $\mathrm{b}$ and $\mathrm{c}$ ) and climatic water deficit (CWD; e and f) between the 30-year periods 1971-2000 and 2040-2069 based on the Geophysical Fluid Dynamics Laboratory (GFDL) and Parallel Climate Model (PCM) climate models and the A2 (medium-high) emissions scenario. In the widespread portion of the Sierra Nevada in which Song Sparrow breeds, both historic exposure to climate variation and projected exposure to climate change are intermediate compared to the Sierra Nevada overall.

\section{Song Sparrow (Melospiza melodia)}

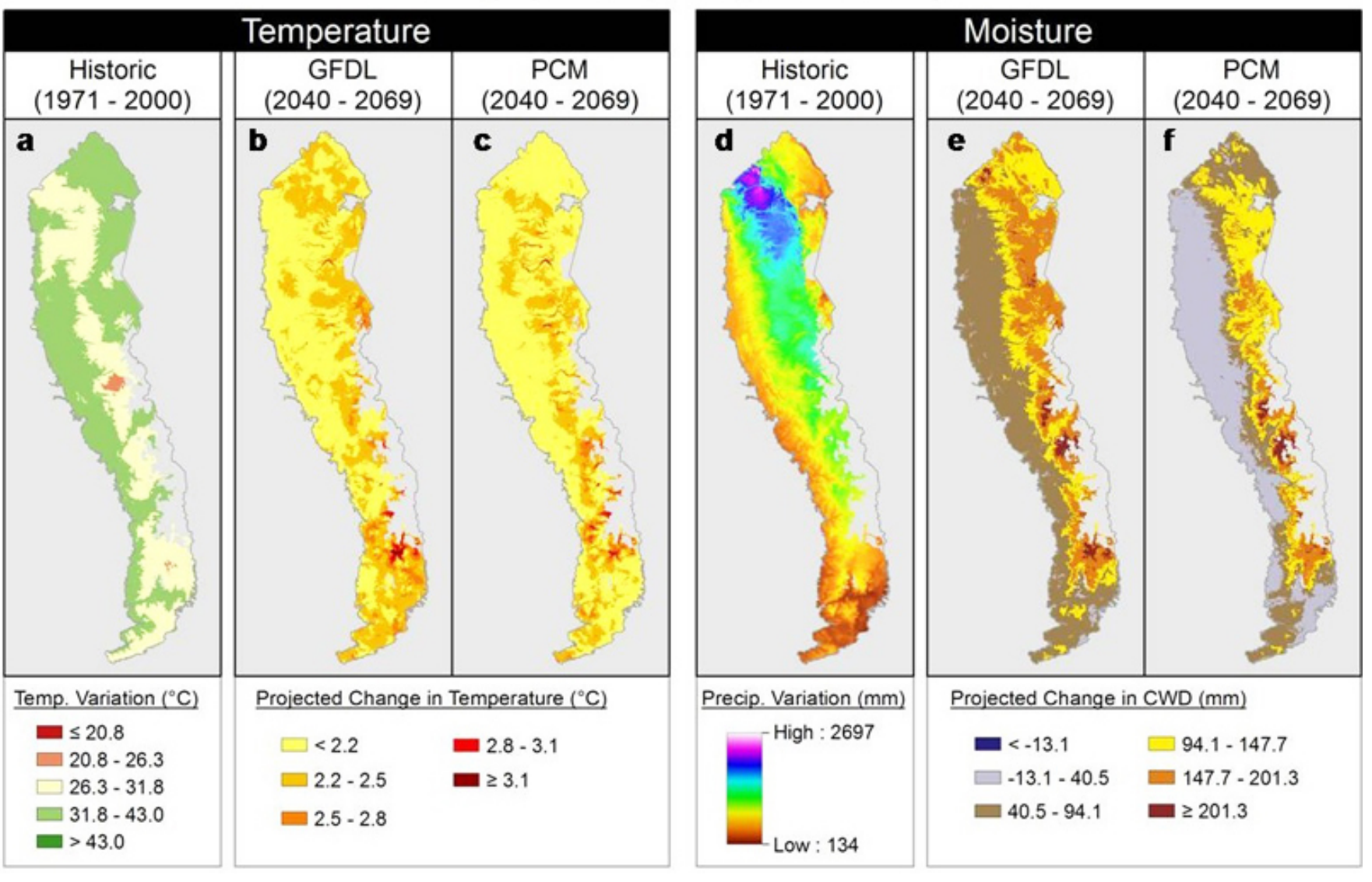

White-tailed Ptarmigan, which scored as the single most vulnerable species in our assessment, is not a native species in the Sierra Nevada or California (Braun et al. 1993). The entire Sierra population apparently stems from the deliberate release of 73 birds near Mono Pass in 1971 and 1972 (Frederick and Gutiérrez 1992). Conservation of the White-tailed Ptarmigan may therefore not be a high priority for most managers in the region, but our results may also have implications for the species within its native range elsewhere in North America.

Our analysis suggested that species associated with aquatic habitats are also significantly more vulnerable to climate change in the Sierra Nevada than other species, at least under the drier GFDL climate model. Species associated with aquatic habitats that ranked as Moderately Vulnerable to climate change based on projections from one or both climate models include Common Merganser (Mergus merganser), Osprey, Bald Eagle (Haliaeetus leucocephalus), Spotted Sandpiper (Actitis macularius), and American Dipper.
A somewhat surprising result of our analysis is that, under climate projections based on the PCM, but not the GFDL, model, species associated with marshes, meadows, and riparian vegetation were significantly less likely to show vulnerability to projected climate change than species associated with other habitats. A predominance of species associated with these habitats (40 of 52) ranked Presumed Stable, with only three species, Spotted Sandpiper, Great Gray Owl (Strix nebulosa), and Swainson's Thrush (Catharus ustulatus) ranking Moderately Vulnerable. By contrast, nine species associated with these habitats are expected to increase under projections based on both climate models, most of them common and widespread species such as American Robin (Turdus migratorius), Song Sparrow, and Brewer's Blackbird (Euphagus cyanocephalus). Seavy et al. (2009) suggest that intact riparian ecosystems may be particularly resilient to climate change, and our results appear to be consistent with this prediction. 
Table 3. Climate change vulnerability rankings and course-scale habitat associations for the 17 species (168 species assessed) that ranked as Moderately Vulnerable or Extremely Vulnerable to climate change in the Sierra Nevada under one or both of the climate projections we assessed. CCVI = Climate Change Vulnerability Index, GFDL = Geophysical Fluid Dynamics Laboratory; PCM = Parallel Climate Model.

\begin{tabular}{|c|c|c|c|}
\hline \multirow[t]{2}{*}{ Common Name } & \multicolumn{2}{|c|}{ CCVI Assessment } & \multirow[t]{2}{*}{ Habitat(s) ${ }^{\dagger}$} \\
\hline & GFDL Climate Model & PCM Climate Model & \\
\hline $\begin{array}{l}\text { Common Merganser } \\
\text { (Mergus merganser) }\end{array}$ & Moderately Vulnerable & Moderately Vulnerable & AQU \\
\hline $\begin{array}{l}\text { White-tailed Ptarmigan } \\
\text { (Lagopus leucura) }\end{array}$ & Extremely Vulnerable & Extremely Vulnerable & SUA \\
\hline $\begin{array}{l}\text { Osprey } \\
\text { (Pandion haliaetus) }\end{array}$ & Moderately Vulnerable & Presumed Stable & $\mathrm{AQU}$ \\
\hline $\begin{array}{l}\text { Bald Eagle } \\
\text { (Haliaeetus leucocephalus) }\end{array}$ & Moderately Vulnerable & Moderately Vulnerable & AQU \\
\hline $\begin{array}{l}\text { Northern Goshawk } \\
\text { (Accipiter gentilis) }\end{array}$ & Moderately Vulnerable & Moderately Vulnerable & $\mathrm{MCF}$ \\
\hline $\begin{array}{l}\text { Peregrine Falcon } \\
\text { (Falco peregrinus) }\end{array}$ & Moderately Vulnerable & Moderately Vulnerable & $\mathrm{MCF}$ \\
\hline $\begin{array}{l}\text { Prairie Falcon } \\
\text { (Falco mexicanus) }\end{array}$ & Moderately Vulnerable & Presumed Stable & MCS \\
\hline $\begin{array}{l}\text { Spotted Sandpiper } \\
\text { (Actitis macularius) }\end{array}$ & Moderately Vulnerable & Moderately Vulnerable & AQU, RMM \\
\hline $\begin{array}{l}\text { Great Gray Owl } \\
(\text { Strix nebulosa) }\end{array}$ & Moderately Vulnerable & Moderately Vulnerable & MCF, RMM \\
\hline $\begin{array}{l}\text { Black Swift } \\
\text { (Cypseloides niger) }\end{array}$ & Moderately Vulnerable & Moderately Vulnerable & $\mathrm{MCF}$ \\
\hline $\begin{array}{l}\text { Clark's Nutcracker } \\
\text { (Nucifraga columbiana) }\end{array}$ & Presumed Stable & Moderately Vulnerable & MCF, SUA \\
\hline $\begin{array}{l}\text { American Dipper } \\
\text { (Cinclus mexicanus) }\end{array}$ & Moderately Vulnerable & Presumed Stable & AQU \\
\hline $\begin{array}{l}\text { Swainson's Thrush } \\
\text { (Catharus ustulatus) }\end{array}$ & Moderately Vulnerable & Moderately Vulnerable & RMM \\
\hline $\begin{array}{l}\text { American Pipit } \\
\text { (Anthus rubescens) }\end{array}$ & Moderately Vulnerable & Moderately Vulnerable & SUA \\
\hline $\begin{array}{l}\text { Gray-crowned Rosy-Finch } \\
\text { (Leucosticte tephrocotis) }\end{array}$ & Moderately Vulnerable & Moderately Vulnerable & SUA \\
\hline $\begin{array}{l}\text { Pine Grosbeak } \\
\text { (Pinicola enucleator) }\end{array}$ & Moderately Vulnerable & Moderately Vulnerable & $\mathrm{MCF}$ \\
\hline $\begin{array}{l}\text { Evening Grosbeak } \\
\text { (Coccothraustes vespertinus) }\end{array}$ & Moderately Vulnerable & Moderately Vulnerable & $\mathrm{MCF}$ \\
\hline
\end{tabular}

Our analysis indicates that many species of foothill woodland and chaparral habitats are significantly less vulnerable to climate change in the region compared with other species, under projections based on both climate models we considered; many such species may undergo range expansions or population increases within the Sierra Nevada region. Twenty species $(29.9 \%)$ associated with these habitats are predicted to benefit from climate change, perhaps through increased population size or range expansion, under both the GDFL and PCM climate models, 11 additional species $(16.4 \%$ ) are predicted to benefit under the more substantial climate change predicted by the GFDL model, and no species received rankings indicating vulnerability to climate change (Table 3). Rankings of Increase Likely for many of these foothill species reflect exposure to relatively broad temperature and precipitation variation in recent years, which are taken to suggest broad physiological and ecological tolerances to variation in temperature and moisture. Similar scoring contributed to rankings of Increase Likely for many montane chaparral and sagebrush species.

A large numbers of species expected to undergo range expansions or population increases in the region occupy drier and warmer foothill habitats, under climatic conditions and in vegetation types that are less likely to change dramatically and may expand upslope (Stralberg et al. 2009). The suggestion that these species might benefit from climate change assumes that species will be able to track appropriate climatic conditions as they shift across the region. Such tracking already appears to be occurring in numerous species (Tingley et al. 2009, 2012), although it is unclear how such shifts might affect regional population sizes over the long-term. 
Table 4. Summary of Climate Change Vulnerability Index rankings for 168 species in the Sierra Nevada as classified by habitat associations.

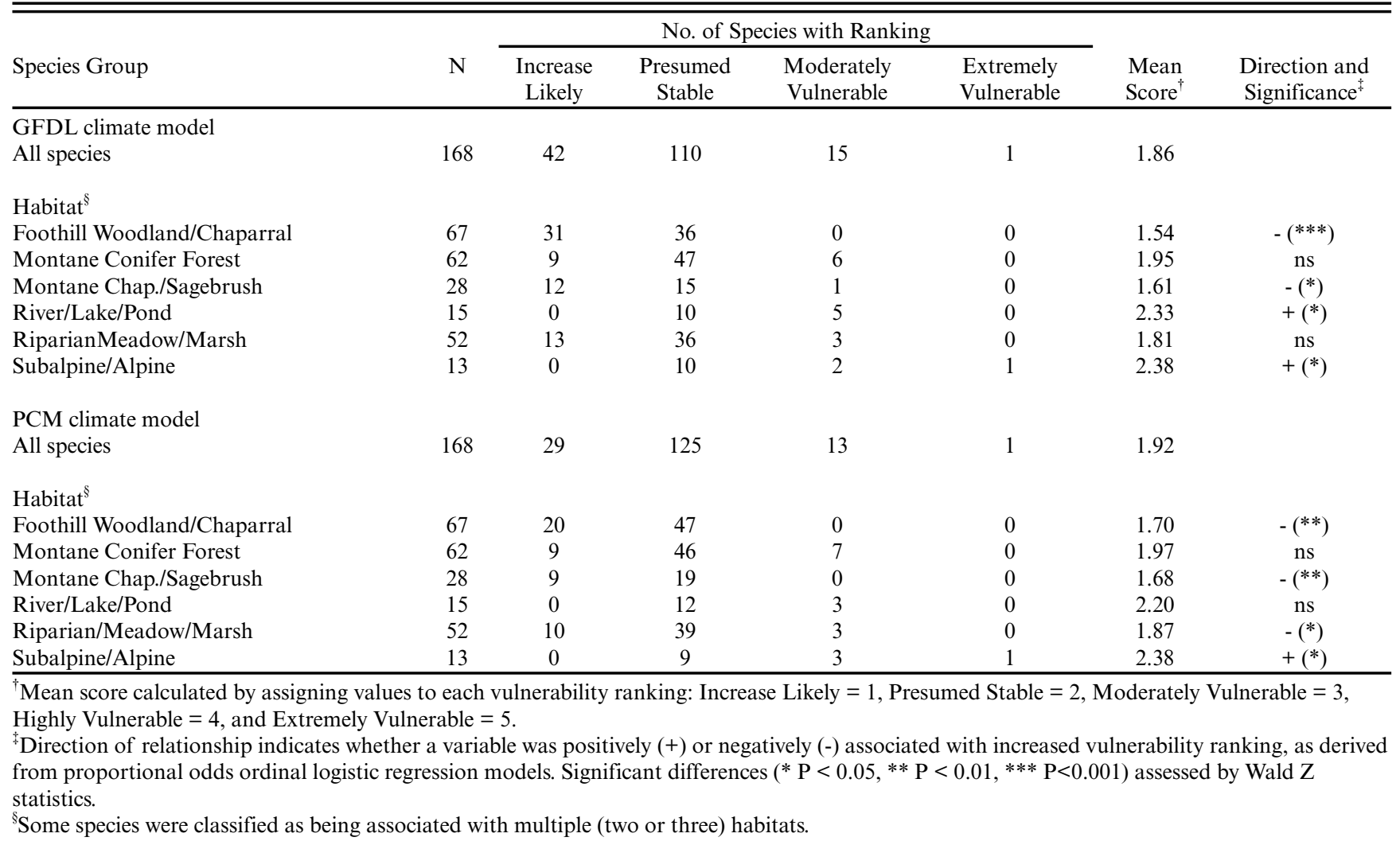

Over the near-term, J. Saracco, R. Siegel, S. Stock, R. Wilkerson, and D. DeSante (unpublished manuscript) corroborate that at least one climatic factor, reduced spring snowpack, may benefit some species in the region. During the period 1993-2010, a preponderance of bird species exhibited higher breeding productivity in Yosemite National Park during years with relatively less spring snowpack. Climate change is expected to dramatically reduce average spring snowpack over the coming decades, a phenomenon that may thus bolster many bird populations in the region. However, Saracco et al. caution that the effects of climate change are likely to be numerous and complex. Earlier snowmelt, for example, is likely to lead to drier midsummer meadow conditions, which might mean reduced food resources or other negative consequences for meadow-associated birds and it is unclear how such factors may weigh against one another to affect population trends.

\section{Effect of range within the Sierra Nevada on vulnerability rankings}

Species with ranges restricted to areas projected to undergo greater climate change tended to have higher overall vulnerability rankings than species restricted to areas where less climate change is projected. For example, Gray-crowned Rosy-Finch, whose breeding range is restricted to alpine/subalpine areas in the southeast portion of the Sierra Nevada Region (Fig. 7), ranked as Moderately Vulnerable using projections from either the
GFDL or PCM climate models, whereas California Thrasher, whose range is restricted to lower-elevation areas along the western margin of the Sierra Nevada (Fig. 5), ranked as Increase Likely under both models. Other factors besides climate change exposure also contributed to these contrasting rankings, but within these two example species' respective ranges, the distribution of land area projected to undergo various magnitudes of warming and especially drying (Fig. 9) differed substantially.

\section{Sensitivity of results to different climate models}

Although climate model selection clearly affected the vulnerability rankings for a minority of species (16 species, or $9.5 \%$ of all species assessed had different vulnerability rankings under the two climate models), no species differed by more than one ranking level under the two climate scenarios, e.g., no species ranked as Increase Likely under one climate scenario, but as Moderately Vulnerable under the other. Because the climate models we used are considered likely to bracket future conditions, we consider our vulnerability rankings to be relatively robust to uncertainties in the climate projections.

\section{Previous climate change vulnerability assessments in California}

Gardali et al. (2012) recently used fairly similar methods to assess climate change vulnerability for selected bird species across 
Fig. 9. Projected changes in temperature and climatic water deficit (CWD) between the periods 1971-2000 and 2040-2069 within the Sierra Nevada breeding ranges of Gray-crowned Rosy-Finch (Leucosticte tephrocotis), a species restricted to breeding in higher elevation portions of the region, and California Thrasher (Toxostoma redivivum), a species restricted to breeding at low elevations on the western slope, under the Geophysical Fluid Dynamics Laboratory (GFDL) and Parallel Climate Model (PCM) climate models. The histograms indicate the number of $270-\mathrm{m}$ cells within each species' Sierra Nevada breeding range projected to undergo the indicated degree of change in temperature or climatic water deficit between the periods 1971-2000 and 2040-2069.

\section{Gray-crowned Rosy-Finch}
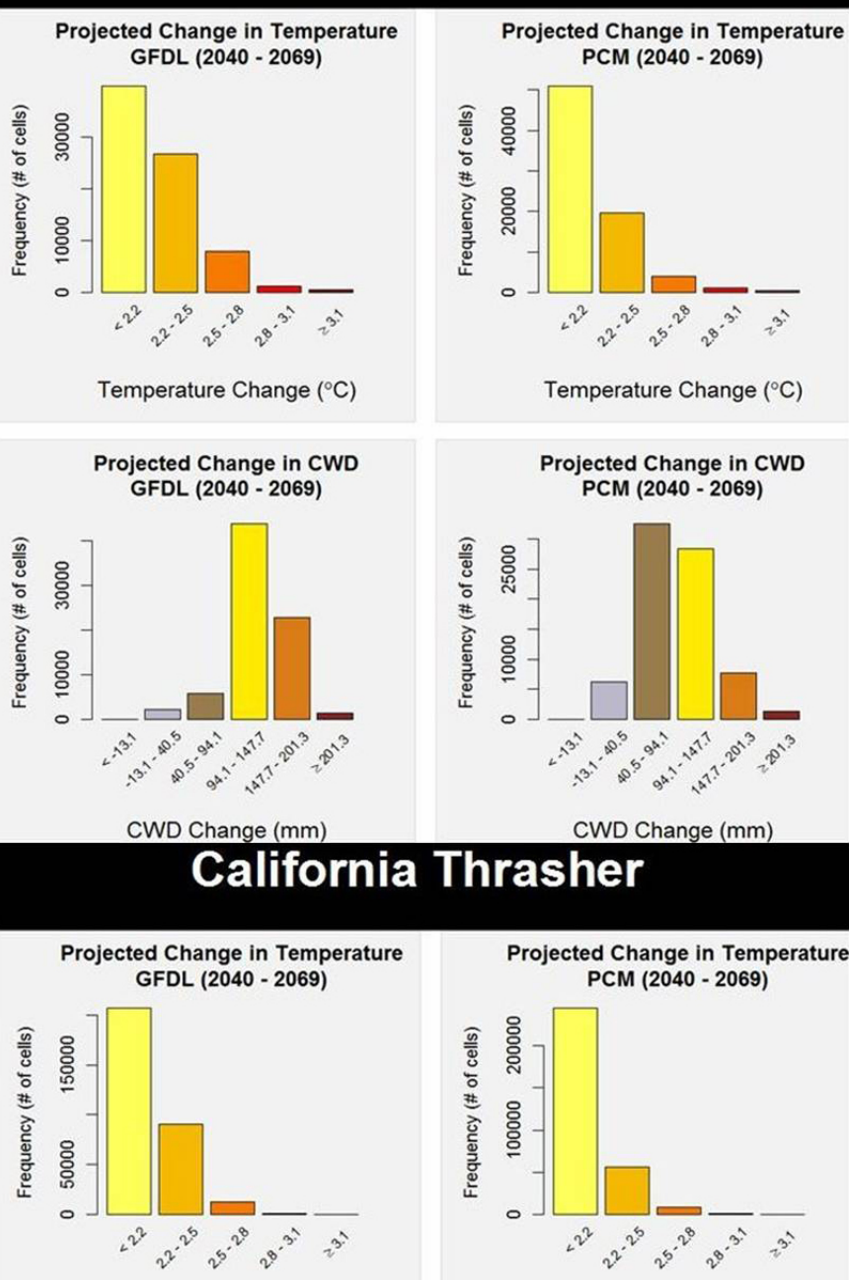

Projected Change in Temperature

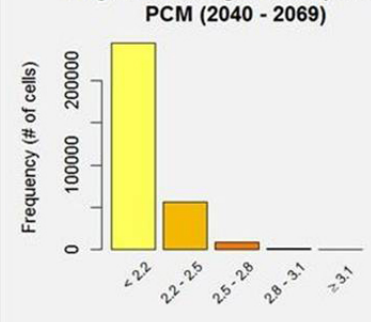

Temperature Change $\left({ }^{\circ} \mathrm{C}\right)$

Temperature Change $\left({ }^{\circ} \mathrm{C}\right)$

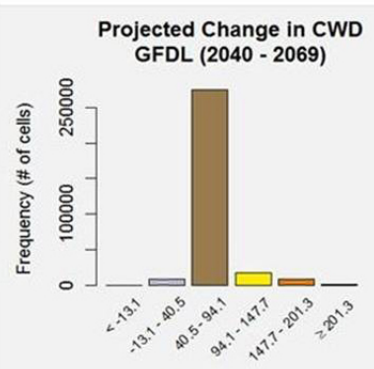

Projected Change in CWD PCM (2040 - 2069)

CWD Change (mm)

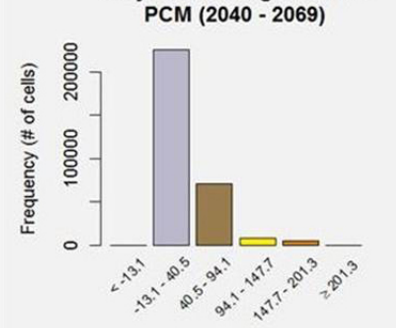

CWD Change (mm) 
California as a whole. However, their analysis included many species associated with marine, desert, and other habitats not present in the Sierra Nevada, and subject to threats, e.g., sea level rise, that are not relevant to the Sierra Nevada region. Nevertheless, for 135 species that we assessed and that were also assessed by Gardali et al., the two sets of vulnerability rankings showed significant concordance using our GFDL-based assessments (proportional odds ordinal logistic regression comparing our CCVI rankings to the continuous vulnerability rankings of Gardali et al.; Wald Z-score $=2.31, \mathrm{P}=0.016$ ) but no significant relationship using our PCM-based assessments (Wald Z-score $=1.41, \mathrm{P}=0.158$ ).

The most important source of differences between our results and those of Gardali et al. (2012) is likely the spatial scales under consideration, i.e., the entire state of California by Gardali et al. (2012) and the Sierra Nevada in our analysis. Our study, like that of Gardali et al., evaluated vulnerability in a spatially explicit context; for species with broader distributions in California than just the Sierra Nevada, projected climate change exposure may vary substantially across the two areas of inference. Indeed, some projections indicate that climate change in other parts of California is likely to be considerably greater than in the Sierra Nevada (e.g., Ackerly et al. 2010). In some cases even indirect exposure to climate change as well as sensitivity to climate change may vary across regions. For these reasons, Gardali et al. noted that the state-wide scale of their assessment in California may not identify taxa vulnerable at smaller spatial scales. These differences in the geographic scope of the data considered and differences in the resulting vulnerability rankings provide a cautionary note about the importance of carefully and explicitly selecting the spatial domain for climate change vulnerability assessments. It should not be assumed that vulnerability to climate change always "scales up" to larger spatial domains, or "scales down" to smaller domains without important changes to species' relative degree of exposure or perhaps even sensitivity to climate change.

Nevertheless, the smaller sets of Sierra Nevada species identified as vulnerable by both studies have substantial commonality, which helps validate the methods of both assessments, and also emphasizes the need to take seriously possible threats faced by the species ranked as vulnerable. Gardali et al. (2012) evaluated 14 of the 17 species that ranked as Moderately Vulnerable or Extremely Vulnerable in our analysis, and considered 6 of them to be climate-vulnerable across California as a whole: Osprey, Great Gray Owl, Black Swift (Cypseloides niger), Swainson's Thrush, Gray-crowned Rosy-Finch, and Pine Grosbeak (Pinicola enucleator). Two more of the 17 species, Peregrine Falcon (Falco peregrinus) and American Dipper, received vulnerability scores only slightly below the cutoff that Gardali et al. (2012) used to separate taxa into vulnerable versus nonvulnerable.

\section{Limitations of our approach}

One limitation of the CCVI methodology is that it incorporates spatially explicit climate projections only within the current range of a given species. Species that are able to shift their ranges to track changing environmental conditions may be able to colonize newly suitable habitat outside their current ranges. The CCVI accounts for this to some degree, as many of the factors scored in Section B (indirect exposure to climate change), Section C (sensitivity to climate change) and Section D (documented response to climate change) are relevant to whether an individual species is likely to be able to shift its range to track appropriate environmental conditions (Table 1). Another limitation to our methodology is that we assessed the vulnerability of species to climate change and associated factors within breeding ranges only; for migratory species we did not consider climate-related threats on the wintering grounds or along migratory routes outside the region. Assessing climate-change vulnerability without explicitly using knowledge of migratory connectivity to incorporate vulnerability factors on the wintering grounds and migratory routes of migratory species has been criticized as an incomplete approach (Small-Lorenz et al. 2013), because many migratory species may face their biggest threats when they are away from their breeding range. Specific data on migratory connectivity are available for few if any Sierra Nevada populations of breeding migratory birds, and we encourage further study on this as well as evaluation of climate-change effects on migration and winter grounds of these species. Despite these limitations, we urge land managers to take seriously the apparent climate-related vulnerability of species ranked as Extremely or Moderately Vulnerable in our analysis, including species that have not yet shown evidence of population declines or range contractions in the region.

\section{CONCLUSION}

We recommend that managers gauge concern for individual bird species in the Sierra Nevada based on likely effects of climate change on those species and their habitats, rather than assuming that all species will be affected negatively. Our results suggest that species vary greatly in their vulnerability to climate change in the region. Interestingly, of the two climate model scenarios we used, the GFDL model projecting more-severe climate change yielded substantially more species predicted to benefit from climate change, but also slightly more species ranked as vulnerable to climate change, than did the PCM model, which projecting less severe climate change.

Our analysis identified 17 bird species that may be particularly vulnerable to climate change in the Sierra Nevada over the coming decades, and also suggests that two broader ecological groups of species, birds associated with subalpine or alpine habitats, and birds associated with aquatic habitats, appear to be more vulnerable than other groups. In contrast, birds associated with foothill habitats, as well as montane chaparral and sagebrush, appear to be less vulnerable and in some cases may benefit from climate change. These findings can help land managers set conservation priorities and develop strategies for bolstering resistance and resilience of the more vulnerable species and habitats. Balancing these efforts with the needs of species that are already jeopardized for other reasons may be a substantial challenge.

Responses to this article can be read online at: http://www.ace-eco.org/issues/responses.php/658

\footnotetext{
Acknowledgments:

This research was funded by a grant from the California Landscape Conservation Cooperative and by grant 500-09-037 of the California Energy Commission, Public Interest Energy Research
} 
program. We thank Rebecca Fris and Debra Schlafmann for assistance with grant administration, Diana Craig for helping to develop the project goals, and Bruce Young for technical assistance using the CCVI. This study was completed by The Institute for Bird Populations' Sierra Nevada Bird Observatory and is Contribution No. 459 of The Institute for Bird Populations.

\section{LITERATURE CITED}

Ackerly, D. D., S. R. Loarie, W. K. Cornwell, S. B. Weiss, H. Hamilton, R. Branciforte, and N. J. B. Kraft. 2010. The geography of climate change: implications for conservation biogeography. Diversity and Distributions 16:476-487. http://dx.doi.org/10.1111/ j.1472-4642.2010.00654.x

Anacker, B., M. Gogol-Prokurat, K. Leidholm, and S. Schoenig. 2013. Climate change vulnerability assessment of rare plants in California. Madroño 60(3):193-210. http://dx.doi.

org/10.3120/0024-9637-60.3.193

Beedy, E. C., and S. L. Granholm. 1985. Discovering Sierra birds. Yosemite and Sequoia Natural History Association, Yosemite National Park, Yosemite, California, USA.

Beedy, E. C., and E. R. Pandolfino. 2013. Birds of the Sierra Nevada. University of California Press, Berkeley, California, USA.

Bonfils, C., B. D. Santer, D. W. Pierce, H. G. Hidalgo, G. Bala, T. Das, T. P. Barnett, D. R. Cayan, C. Doutriaux, A. W. Wood, A. Mirin, and T. Nozawa. 2008. Detection and attribution of temperature changes in the mountainous western United States. Journal of Climate 21:6404-6424. http://dx.doi.org/10.1175/2008JCLI2397.1

Both, C., S. Bouwhuis, C. M. Lessells, and M. E. Visser. 2006. Climate change and population declines in a long-distance migratory bird. Nature 441:81-83. http://dx.doi.org/10.1038/ nature04539

Braun, C. E., K. Martin, and L. A. Robb. 1993. White-tailed Ptarmigan (Lagopus leucura). A. Poole, editor. The birds of North America online. Cornell Lab of Ornithology, Ithaca, New York, USA. [online] URL: http://bna.birds.cornell.edu/bna/species/068

Cayan, D. R., E. P. Maurer, M. D. Dettinger, M. Tyree, and K. Hayhoe. 2008. Climate change scenarios for the California region. Climatic Change 87(Suppl 1):S21-S42. http://dx.doi.org/10.1007/ s10584-007-9377-6

Crimmins, S. M., S. Z. Dobrowski, J. A. Greenberg, J. T. Abatzoglou, and A. R. Mynsberge. 2011. Changes in climatic water balance drive downhill shifts in plant species' optimum elevations. Science 331:324-327. http://dx.doi.org/10.1126/ science. 1199040

Davis, F., and D. Stoms. 2012. Appendix SN. The Sierra Nevada region. University of California at Santa Barbara Biogeography Lab, Santa Barbara, California, USA. [online] URL: http://www. biogeog.ucsb.edu/projects/gap/report/sn_rep.html

Delworth, T. L., A. J. Broccoli, A. Rosati, R. J. Stouffer, V. Balaji, J. A. Beesley, W. F. Cooke, K. W. Dixon, J. Dunne, K. A. Dunne, J. W. Durachta, K. L. Findell, P. Ginoux, A. Gnanadesikan, C. T. Gordon, S. M. Griffies, R. Gudgel, M. J. Harrison, I. M. Held,
R. S. Hemler, L. W. Horowitz, S. A. Klein, T. R. Knutson, P. K. Kushner, A. R. Langenhorst, H.-C. Lee, S.-J. Lin, J. Lu, S. L. Malyshev, P. C. D. Milly, V. Ramaswamy, J. Russell, M. D. Schwarzkopf, E. Shevlakova, J. J. Sirutis, M. J. Spelman, W. F. Stern, M. Winton, A. T. Wittenberg, B. Wyman, F. Zeng, and R. Zhang. 2006. GFDL's CM2 global coupled climate models. Part I: formulation and simulation characteristics. Journal of Climate 19:643-674. http://dx.doi.org/10.1175/JCLI3629.1

Dettinger, M. D., D. R. Cayan, M. Meyer, and A. E. Jeton. 2004. Simulated hydrologic responses to climate variations and change in the Merced, Carson, and American River basins, Sierra Nevada, California, 1900-2099. Climatic Change 62:283-317. http://dx.doi.org/10.1023/B:CLIM.0000013683.13346.4f

Dolanc, C. R., J. H. Thorne, and H. D. Safford. 2013. Widespread shifts in the demographic structure of subalpine forests in the Sierra Nevada, California, 1934 to 2007. Global Ecology and Biogeography 22:264-276. http://dx.doi.org/10.1111/ j.1466-8238.2011.00748.x

Dubois, N., A. Caldas, J. Boshoven, and A. Delach. 2011. Integrating climate change vulnerability assessments into adaptation planning: a case study using the NatureServe Climate Change Vulnerability Index to inform conservation planning for species in Florida. Final Report. Defenders of Wildlife, Washington, D.C., USA.

Flint, L. E., and A. L. Flint. 2007. Regional analysis of groundwater recharge. Pages 29-59 in D. A. Stonestrom, J. Constantz, T. P. A. Ferré, and S. A. Leake, editors. Ground-water recharge in the arid and semiarid southwestern United States. United States Geologic Survey Professional Paper 1703. USGS Information Services, Denver, Colorado, USA.

Flint, L. E., and A. L. Flint. 2012. Downscaling future climate scenarios to fine scales for hydrologic and ecological modeling and analysis. Ecological Processes 1:2. http://dx.doi.

org/10.1186/2192-1709-1-2

Flint, L. E., A. L. Flint, J. H. Thorne, and R. M. Boynton. 2013. Fine-scale hydrologic modeling for regional landscape applications: the California Basin characterization model development and performance. Ecological Processes 2:25. [online] URL: http://www.ecologicalprocesses.com/content/2/1/25

Frederick, G. F., and R. J. Gutiérrez. 1992. Habitat use and population characteristics of the White-tailed Ptarmigan in the Sierra Nevada, California. Condor 94:889-902. http://dx.doi. org/10.2307/1369286

Gaines, D. 1992. Birds of Yosemite and the East Slope. Second printing. Artemisia Press, Lee Vining, California, USA.

Gardali, T., N. E. Seavy, R. T. DiGaudio, and L. A. Comrack. 2012. A climate change vulnerability assessment of California's at-risk birds. PLoS ONE 7(3):e29507. http://dx.doi.org/10.1371/ journal.pone.0029507

Grinnell, J., and A. H. Miller. 1944. The distribution of the birds of California. Pacific Coast Avifauna 27:1-608.

Hamon, W. R. 1961. Estimating potential evapotranspiration. Journal of the Hydraulics Division, Proceedings of the American Society of Civil Engineers 87:107-120. 
Hansen, L. J., and J. R. Hoffman. 2011. Climate savvy: adapting conservation and resource management to a changing world. Island Press, Washington, D.C., USA. http://dx.doi. org/10.5822/978-1-59726-988-9

Harrell, F. E., Jr. 2012. rms: Regression modeling strategies. R package version 3.5-0. The R Project for Statistical Computing, Vienna, Austria. [online] URL: http://CRAN.R-project.org/ package $=$ rms

Hayhoe, K., D. Cayan, C. B. Field, P. C. Frumhoff, E. P. Maurer, N. L. Miller, S. C. Moser, S. H. Schneider, K. N. Cahill, E,. E. Cleland, L. Dale, R. Drapek, R. M. Hanemann, L. S. Kalkstein, J. Lenihan, C. K. Lunch, R. P. Neilson, S. C. Sheridan, and J. H. Verville. 2004. Emissions pathways, climate change, and impacts on California. Proceedings of the National Academy of Sciences of the United States of America 101:12422-12427. http://dx.doi. org/10.1073/pnas.0404500101

Hickman, J. C., editor. 1993. Jepson Manual, vascular plants of California. Second edition. University of California Press, Berkeley, California, USA.

Huntley, B., Y. C. Collingham, S. G. Willis, and R. E. Green. 2008. Potential impacts of climatic change on European breeding birds. PLoS ONE 3:e1439. http://dx.doi.org/10.1371/journal.pone.0001439

Intergovernmental Panel on Climate Change (IPCC). 2007. Climate Change 2007: the physical science basis. Contribution of Working Group I to the Fourth Assessment Report of the Intergovernmental Panel on Climate Change. S. Solomon, D. Qin, M. Manning, Z. Chen, M. Marquis, K. B. Avery, M. Tignor, and H. L. Miller, editors. Cambridge University Press, Cambridge, UK.

Jongsomjit, D., S. Veloz, D. Stralberg, M. Fitzgibbon, C. Howell, D. Moody, S. Michaile, and G. Ballard. 2011. Modeling bird distribution responses to climate change: a mapping tool to assist land managers and scientists in California. Version 2. [Web application]. Petaluma, California, USA. [online] URL: http:// data.prbo.org/cadc/tools/ccweb2/index.php

Knowles, N., and D. R. Cayan. 2002. Potential effects of global warming on the Sacramento/San Joaquin watershed and the San Francisco estuary. Geophysical Research Letters 29:38-1-38-4. http://dx.doi.org/10.1029/2001GL014339

Knowles, N., and D. R. Cayan. 2004. Elevational dependence of projected hydrologic changes in the San Francisco estuary and watershed. Climatic Change 62:319-336. http://dx.doi.org/10.1023/ B:CLIM.0000013696.14308.b9

Lenihan, J. M., D. Bachelet, R. P. Neilson, and R. Drapek. 2008. Response of vegetation distribution, ecosystem productivity, and fire to climate change scenarios for California. Climatic Change 87:S215-S230. http://dx.doi.org/10.1007/s10584-007-9362-0

Loarie, S. R., P. B. Duffy, H. Hamilton, G. P. Asner, C. B. Field, and D. D. Ackerly. 2009. The velocity of climate change. Nature 462:1052-1055. http://dx.doi.org/10.1038/nature08649

Lukas, D. 2011. Sierra Nevada birds. Lukas Guides, Big Oak Flat, California, USA.

Lutz, J. A., J. W. van Wagtendonk, and J. F. Franklin. 2010. Climatic water deficit, tree species ranges, and climate change in
Yosemite National Park. Journal of Biogeography 37:936-950. http://dx.doi.org/10.1111/j.1365-2699.2009.02268.x

Maurer, E. P. 2007. Uncertainty in hydrologic impacts of climate change in the Sierra Nevada, California, under two emissions scenarios. Climatic Change 82:309-325. http://dx.doi.org/10.1007/ s10584-006-9180-9

McCullagh, P. 1980. Regression models for ordinal data (with discussion). Journal of the Royal Statistical Society, Series B 42:109-142.

Meehl, G. A., W. M. Washington, T. M. L. Wigley, J. M. Arblaster, and A. Dai. 2003. Solar and greenhouse gas forcing and climate response in the twentieth century. Journal of Climate 16:426-444. http://dx.doi.org/10.1175/1520-0442(2003)016<0426:SAGGFA>2.0. $\mathrm{CO} ; 2$

Millar, C. I., R. D. Westfall, D. L. Delany, J. C. King, and L. J. Graumlich. 2004. Response of subalpine conifers in the Sierra Nevada, California, USA, to 20th-century warming and decadal climate variability. Arctic, Antarctic, and Alpine Research 36:181-200. http://dx.doi.org/10.1657/1523-0430(2004)036[0181: ROSCIT]2.0.CO;2

Möller, A. P., D. Rubolini, and E. Lehikoinen. 2008. Populations of migratory bird species that did not show a phenological response to climate change are declining. Proceedings of the National Academy of Sciences of the United States of America 105:16195-16200. http://dx.doi.org/10.1073/pnas.0803825105

Moritz, C., J. L. Patton, C. J. Conroy, J. L. Parra, G. C. White. and S. R. Beissinger. 2008. Impact of a century of climate change on small-mammal communities in Yosemite National Park, USA. Science 322(5899):261-264. http://dx.doi.org/10.1126/science.1163428

Ohlemüller, R., B. J. Anderson, M.B. Araújo, S. H. M. Butchart, O. Kudrna, R. S. Ridgely, and C. D. Thomas. 2008. The coincidence of climatic and species rarity: high risk to small-range species from climate change. Biology Letters 4:568-572. http://dx. doi.org/10.1098/rsbl.2008.0097

Poole, A., editor. 2005. The birds of North America online. Cornell Laboratory of Ornithology, Ithaca, New York, USA. [online] URL: http://bna.birds.cornell.edu/BNA/

PRBO Conservation Science. 2011. Projected effects of climate change in California: ecoregional summaries emphasizing consequences for wildlife. Version 1.0. PRBO Conservation Science, Petaluma, California, USA. [online] URL: http://data. prbo.org/apps/bssc/climatechange

Seavy, N. E., T. Gardali, G. H. Golet, F. T. Griggs, C. A. Howell, R. Kelsey, S. L. Small, J. H. Viers, and J. F. Weigand. 2009. Why climate change makes riparian restoration more important than ever: recommendations for practice and research. Ecological Restoration 27:330-338. http://dx.doi.org/10.3368/er.27.3.330

Shuford, W. D., and T. Gardali, editors. 2008. California bird species of special concern: a ranked assessment of species, subspecies, and distinct populations of birds of immediate conservation concern in California. Studies of Western Birds I. Western Field Ornithologists, Camarillo, California, and California Department of Fish and Game, Sacramento, California, USA. 
Siegel, R. B., and D. F. DeSante. 1999. Draft avian conservation plan for the Sierra Nevada bioregion: a report to California Partners in Flight. The Institute for Bird Populations, Point Reyes Station, California, USA.

Small-Lorenz, S. L., L. A. Culp, T. B. Ryder, T. C. Will, and P. P. Marra. 2013. A blind spot in climate change vulnerability assessments. Nature Climate Change 3:91-93. http://dx.doi. org/10.1038/nclimate1810

Steel, Z. L., M. L. Bond, R. B. Siegel, and P. Pyle. 2012. Avifauna of Sierra Nevada Network parks: assessing distribution, abundance, stressors, and conservation opportunities for 145 bird species. Natural Resource Report NPS/SIEN/NRR_2012/506. National Park Service, Fort Collins, Colorado, USA.

Stephenson, N. L. 1998. Actual evapotranspiration and deficit: biologically meaningful correlates of vegetation distribution across spatial scales. Journal of Biogeography 25:855-870. http:// dx.doi.org/10.1046/j.1365-2699.1998.00233.x

Stouffer, R. J., A. J. Broccoli, T. L. Delworth, K. W. Dixon, R. Gudgel, I. Held, R. Hemler, T. Knutson, H.-C. Lee, M. D. Schwarzkopf, B. Soden, M. J. Spelman, M. Winton, and F. Zeng. 2006. GFDL's CM2 global coupled climate models. Part IV: Idealized climate response. Journal of Climate 19:723-740. http:// dx.doi.org/10.1175/JCLI3632.1

Stralberg, D., D. Jongsomjit, C. A. Howell, M. A. Snyder, J. D. Alexander, A. Wiens, and T. L. Root. 2009. Re-shuffling of species with climate disruption: a no-analog future for California birds? PLoS ONE 4:e6825. http://dx.doi.org/10.1371/journal.pone.0006825

Thorne, J. H., R. Boynton, T. N. Le, A. Flint, and L. Flint. 2012. Development and application of downscaled hydroclimatic predictor variables for use in cross-sector climate vulnerability and assessment studies. CEC-500-2011-009. California Energy Commission, Sacramento, California, USA.

Thorne, J. H., B. J. Morgan, and J. A. Kennedy. 2008. Vegetation change over sixty years in the central Sierra Nevada, California, USA. Madroño 55:223-237. http://dx.doi.org/10.3120/0024-9637-55.3.223

Tingley, M. W. and S. R. Beissinger. 2013. Cryptic loss of montane avian richness and high community turnover over 100 years. Ecology 94:598-609. http://dx.doi.org/10.1890/12-0928.1

Tingley, M. W., M. S. Koo, C. Moritz, A. C. Rush, and S. R. Beissinger. 2012. The push and pull of climate change causes heterogeneous shifts in avian elevational ranges. Global Change Biology 18:3279-3290. http://dx.doi.org/10.1111/j.1365-2486.2012.02784. $\mathrm{x}$

Tingley, M. W., W. B. Monahan, S. R. Beissinger, and C. Moritz. 2009. Birds track their Grinnellian niche through a century of climate change. Proceedings of the National Academy of Sciences of the United States of America 106:19637-19643. http://dx.doi. org/10.1073/pnas.0901562106

van Mantgem, P. J., and N. L. Stephenson. 2007. Apparent climatically induced increase of tree mortality rates in a temperate forest. Ecology Letters 10:909-916. http://dx.doi.org/10.1111/ j.1461-0248.2007.01080.x

Walk, J., S. Hagen, and A. Lange. 2011. Adapting conservation to a changing climate: an update to the Illinois Wildlife Action Plan. Report to the Illinois Department of Natural Resources. Illinois Chapter of the Nature Conservancy, Peoria, Illinois, USA.

Washington, W. M., J. W. Weatherly, G. A. Meehl, A. J. Semtner, T. W. Bettge, A. P. Craig, W. G. Strand, J. Arblaster, V. B. Wayland, R. James, and Y. Zhang. 2000. Parallel climate model (PCM) control and transient simulations. Climate Dynamics 16:755-774. http://dx.doi.org/10.1007/s003820000079

Young, B. E., E. Byers, K. Gravuer, K. Hall, G. Hammerson, and A. Redder. 2011. NatureServe guidelines for using the NatureServe Climate Change Vulnerability Index (Release 2.1, 7 April 2011). NatureServe, Arlington, Virginia, USA.

Young, B. E., E. Byers, K. Gravuer, K. R. Hall, G. A. Hammerson, A. Redder, K. Szabo, and J. E. Newmark. 2009. Using the NatureServe Climate Change Vulnerability Index: a Nevada case study. NatureServe, Arlington, Virginia, USA.

Young, B. E., K. R. Hall, E. Byers, K. Gravuer, G. Hammerson, A. Redder, and K. Szabo. 2012. Rapid assessment of plant and animal vulnerability to climate change. Pages 129-152 in J. Brodie, E. Post, and D. Doak, editors. Conserving wildlife populations in a changing climate. University of Chicago Press, Chicago, Illinois, USA.

Zeiner, D. C., W. F. Laudenslayer, K. E. Mayer, and M. White. 1990. California's wildlife, Volume II, birds. State of California Department of Fish and Game, Sacramento, California, USA.
Editor-in-Chief: Ryan Norris Subject Editor: Katie E.Sieving
Sponsored by the Society of Canadian Ornithologists and Bird Studies Canada Parrainée par la Société des ornithologistes du Canada et Études d'oiseaux Canada

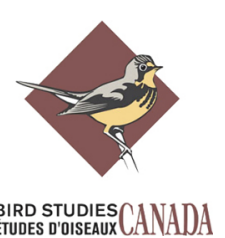


Appendix 1. Climate change vulnerability rankings, current special-status designations in California, and course-scale habitat associations for 168 bird species that breed in the Sierra Nevada.

\begin{tabular}{|c|c|c|c|c|}
\hline \multirow{2}{*}{$\begin{array}{l}\text { Common Name } \\
\text { (Scientific Name) }\end{array}$} & \multicolumn{2}{|c|}{ CCVI Assessment } & \multirow{2}{*}{$\begin{array}{l}\text { California } \\
\text { Special } \\
\text { Status }^{\dagger}\end{array}$} & \multirow[b]{2}{*}{ Habitat(s) $)^{\ddagger}$} \\
\hline & GFDL Climate Model & PCM Climate Model & & \\
\hline $\begin{array}{l}\text { Wood Duck } \\
\text { (Aix sponsa) } \\
\text { Mallard }\end{array}$ & Presumed Stable & Presumed Stable & & AQU \\
\hline $\begin{array}{l}\text { (Anas platyrhynchos) } \\
\text { Harlequin Duck }\end{array}$ & Presumed Stable & Presumed Stable & & AQU, RMM \\
\hline $\begin{array}{l}\text { (Histrionicus histrionicus) } \\
\text { Bufflehead }\end{array}$ & Presumed Stable & Presumed Stable & $\mathrm{S} 2, \mathrm{BSSC}$ & AQU \\
\hline (Bucephala albeola) & Presumed Stable & Presumed Stable & & AQU \\
\hline $\begin{array}{l}\text { Common Merganser } \\
\text { (Mergus merganser) }\end{array}$ & Moderately Vulnerable & Moderately Vulnerable & & AQU \\
\hline $\begin{array}{l}\text { Mountain Quail } \\
\text { (Oreortyx pictus) }\end{array}$ & Presumed Stable & Presumed Stable & & MCS \\
\hline $\begin{array}{l}\text { California Quail } \\
\text { (Callipepla californica) } \\
\text { White-tailed Ptarmigan }\end{array}$ & Presumed Stable & Presumed Stable & & FWC \\
\hline $\begin{array}{l}\text { (Lagopus leucura) } \\
\text { Sooty Grouse }\end{array}$ & Extremely Vulnerable & Extremely Vulnerable & & SUA \\
\hline $\begin{array}{l}\text { (Dendragapus fuliginosus) } \\
\text { Wild Turkey }\end{array}$ & Presumed Stable & Presumed Stable & & $\mathrm{MCF}$ \\
\hline $\begin{array}{l}\text { (Meleagris gallopavo) } \\
\text { Pied-billed Grebe }\end{array}$ & Increase Likely & Presumed Stable & & FWC \\
\hline $\begin{array}{l}\text { (Podilymbus podiceps) } \\
\text { Great Blue Heron }\end{array}$ & Presumed Stable & Presumed Stable & & AQU \\
\hline $\begin{array}{l}\text { (Ardea herodias) } \\
\text { Turkey Vulture }\end{array}$ & Presumed Stable & Presumed Stable & $\mathrm{S} 4$ & AQU, RMM \\
\hline (Cathartes aura) & Presumed Stable & Presumed Stable & & FWC \\
\hline
\end{tabular}




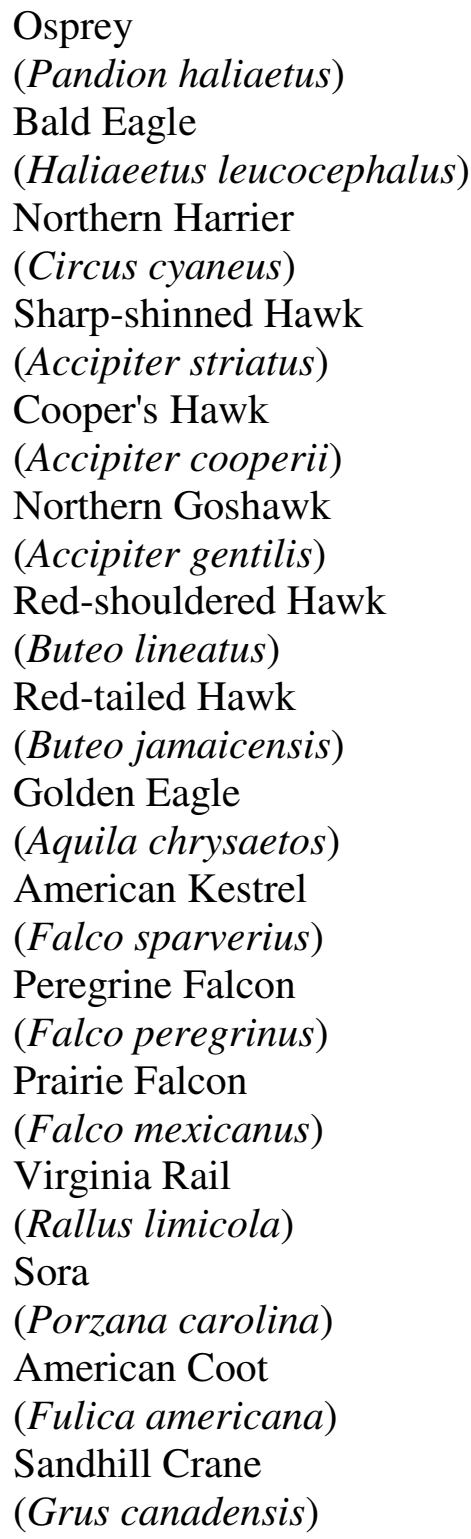

\begin{tabular}{|c|c|c|c|}
\hline Moderately Vulnerable & Presumed Stable & S3 & AQU \\
\hline Moderately Vulnerable & Moderately Vulnerable & $\mathrm{S} 2, \mathrm{E}$ & AQU \\
\hline Presumed Stable & Presumed Stable & $\mathrm{S} 3, \mathrm{BSSC}$ & RMM \\
\hline Presumed Stable & Presumed Stable & S3 & $\mathrm{MCF}$ \\
\hline Presumed Stable & Presumed Stable & S3 & FWC \\
\hline Moderately Vulnerable & Moderately Vulnerable & S3, BSSC & MCF \\
\hline Presumed Stable & Presumed Stable & & FWC, RMM \\
\hline Increase Likely & Increase Likely & & FWC, MCS \\
\hline Presumed Stable & Presumed Stable & & FWC, MCS \\
\hline Presumed Stable & Presumed Stable & & FWC \\
\hline Moderately Vulnerable & Moderately Vulnerable & $\mathrm{S} 2$ & MCF \\
\hline Moderately Vulnerable & Presumed Stable & S3 & MCS \\
\hline Presumed Stable & Presumed Stable & & $\mathrm{RMM}$ \\
\hline Presumed Stable & Presumed Stable & & RMM \\
\hline Presumed Stable & Presumed Stable & & AQU \\
\hline Presumed Stable & Presumed Stable & $\mathrm{S} 2, \mathrm{~T}$ & $\mathrm{RMM}$ \\
\hline
\end{tabular}




\section{Killdeer}

(Charadrius vociferus)

Spotted Sandpiper

(Actitis macularius)

Wilson's Snipe

(Gallinago delicata)

Black Tern

(Chlidonias niger)

Band-tailed Pigeon

(Patagioenas fasciata)

Mourning Dove

(Zenaida macroura)

Yellow-billed Cuckoo

(Coccyzus americanus)

Greater Roadrunner

(Geococcyx californianus)

Barn Owl

(Tyto alba)

Flammulated Owl

(Otus flammeolus)

Western Screech-Owl

(Megascops kennicottii)

Great Horned Owl

(Bubo virginianus)

Northern Pygmy-Owl

(Glaucidium gnoma)

Spotted Owl

(Strix occidentalis)

Great Gray Owl

(Strix nebulosa)

Long-eared Owl

(Asio otus)

$$
\text { Presumed Stable }
$$

Presumed Stable

RMM

Moderately Vulnerable Moderately Vulnerable

Presumed Stable $\quad$ Presumed Stable

Presumed Stable Presumed Stable

Presumed Stable

Presumed Stable

Increase Likely

Increase Likely

Presumed Stable

Presumed Stable

Presumed Stable

Presumed Stable

Presumed Stable

Presumed Stable

Presumed Stable

Presumed Stable

Presumed Stable

Presumed Stable

Presumed Stable

Presumed Stable

Presumed Stable

Presumed Stable

Presumed Stable

Presumed Stable

Moderately Vulnerable

Moderately Vulnerable

Presumed Stable
Presumed Stable
S3, BSSC

S2, BSSC

AQU, RMM

FWC, MCF

FWC, MCS

S1, E

RMM

FWC

FWC, RMM

S3

MCF

FWC

FWC, MCF, MCS

$\mathrm{MCF}$

MCF

S1, E

MCF, RMM

S3, BSSC
RMM 
Northern Saw-whet Owl

(Aegolius acadicus)

Common Nighthawk

(Centralhordeiles minor)

Common Poorwill

(Phalaenoptilus nuttallii)

Black Swift

(Cypseloides niger)

Vaux's Swift

(Chaetura vauxi)

White-throated Swift

(Aeronautes saxatalis)

Black-chinned Hummingbird

(Archilochus alexandri)

Anna's Hummingbird

(Calypte anna)

Calliope Hummingbird

(Stellula calliope)

Rufous Hummingbird

(Selasphorus rufus) $^{\S}$

Belted Kingfisher

(Megaceryle alcyon)

Lewis's Woodpecker

(Melanerpes lewis)

Acorn Woodpecker

(Melanerpes formicivorus)

Williamson's Sapsucker

(Sphyrapicus thyroideus)

Red-breasted Sapsucker

(Sphyrapicus ruber)

Nuttall's Woodpecker

(Picoides nuttallii)

\section{Presumed Stable}

Increase Likely

Increase Likely

Moderately Vulnerable

Presumed Stable

Presumed Stable

Presumed Stable

Presumed Stable

Presumed Stable

Presumed Stable

Presumed Stable

Presumed Stable

Increase Likely

Presumed Stable

Presumed Stable

Presumed Stable
Presumed Stable

Increase Likely

S3

Increase Likely

Moderately Vulnerable

S2, BSSC

Presumed Stable

S3, BSSC

Presumed Stable

Presumed Stable

Presumed Stable

Presumed Stable

Presumed Stable

Presumed Stable

Presumed Stable

Presumed Stable

Presumed Stable

Presumed Stable

Presumed Stable
MCF

MCF, MCS

FWC, MCS

$\mathrm{MCF}$

MCF, RMM

MCF

FWC

FWC

MCF

MCF, RMM

AQU

FWC

FWC

MCF

MCF, RMM

FWC 
Downy Woodpecker

(Picoides pubescens)

Hairy Woodpecker

(Picoides villosus)

White-headed Woodpecker

(Picoides albolarvatus)

Black-backed Woodpecker

(Picoides arcticus)

Northern Flicker

(Colaptes auratus)

Pileated Woodpecker

(Dryocopus pileatus)

Olive-sided Flycatcher

(Contopus cooperi)

Western Wood-Pewee

(Contopus sordidulus)

Willow Flycatcher

(Empidonax traillii)

Hammond's Flycatcher

(Empidonax hammondii)

Gray Flycatcher

(Empidonax wrightii)

Dusky Flycatcher

(Empidonax oberholseri)

Pacific-slope Flycatcher

(Empidonax difficilis)

Black Phoebe

(Sayornis nigricans)

Say's Phoebe

(Sayornis saya)

Ash-throated Flycatcher

(Myiarchus cinerascens)

\begin{tabular}{|c|c|c|c|}
\hline Presumed Stable & Presumed Stable & & RMM \\
\hline Increase Likely & Increase Likely & & $\mathrm{MCF}$ \\
\hline Presumed Stable & Presumed Stable & & $\mathrm{MCF}$ \\
\hline Presumed Stable & Presumed Stable & & $\mathrm{MCF}$ \\
\hline Increase Likely & Increase Likely & & FWC, MCF \\
\hline Presumed Stable & Presumed Stable & & $\mathrm{MCF}$ \\
\hline Presumed Stable & Presumed Stable & S4, BSSC & $\mathrm{MCF}$ \\
\hline Increase Likely & Increase Likely & & FWC, MCF, RMM \\
\hline Presumed Stable & Presumed Stable & $\mathrm{S} 1, \mathrm{E}$ & RMM \\
\hline Presumed Stable & Presumed Stable & & $\mathrm{MCF}$ \\
\hline Increase Likely & Increase Likely & & MCS \\
\hline Presumed Stable & Presumed Stable & & MCF, SUA \\
\hline Presumed Stable & Presumed Stable & & FWC, MCF \\
\hline Presumed Stable & Presumed Stable & & RMM \\
\hline Presumed Stable & Presumed Stable & & MCS \\
\hline Increase Likely & Increase Likely & & FWC \\
\hline
\end{tabular}




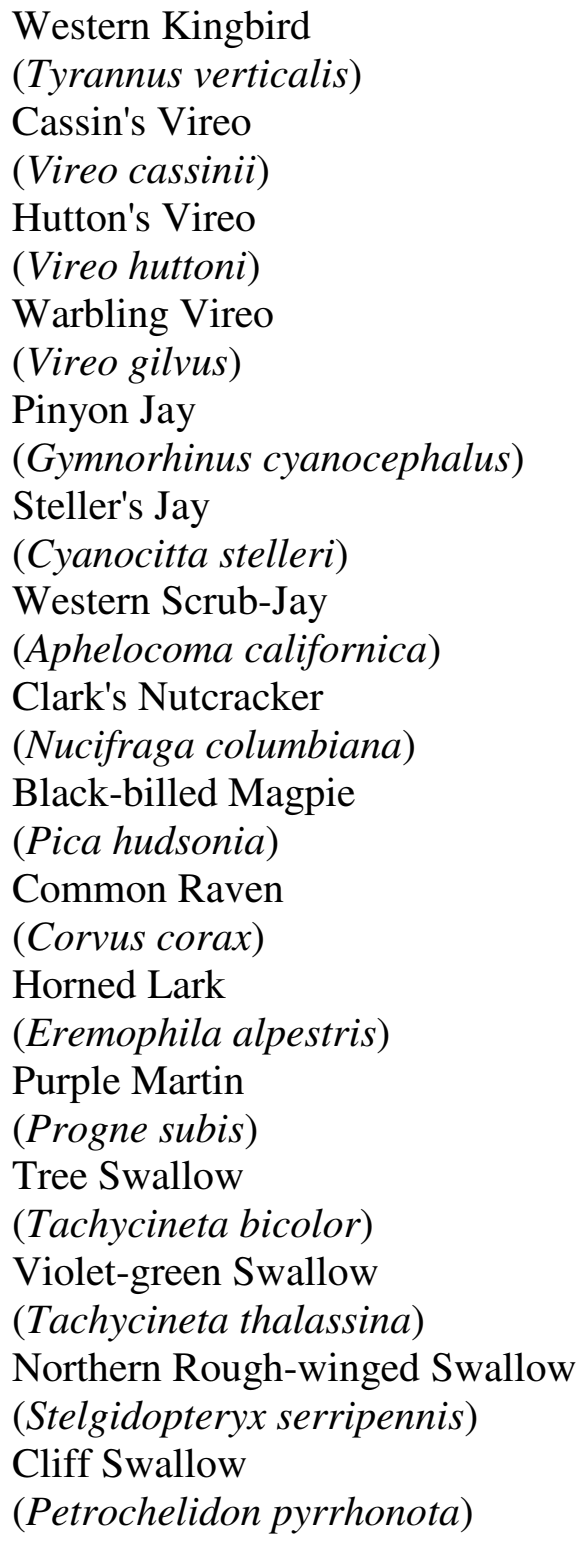

$\begin{array}{cc}\text { Increase Likely } & \text { Increase Likely } \\ \text { Presumed Stable } & \text { Presumed Stable } \\ \text { Increase Likely } & \text { Presumed Stable } \\ \text { Presumed Stable } & \text { Presumed Stable } \\ \text { Presumed Stable } & \text { Presumed Stable } \\ \text { Increase Likely } & \text { Increase Likely } \\ \text { Increase Likely } & \text { Increase Likely } \\ \text { Presumed Stable } & \text { Moderately Vulnerable } \\ \text { Increase Likely } & \text { Presumed Stable } \\ \text { Presumed Stable } & \text { Presumed Stable } \\ \text { Presumed Stable } & \text { Presumed Stable } \\ \text { Presumed Stable } & \text { Presumed Stable } \\ \text { Presumed Stable } & \text { Presumed Stable } \\ \text { Presumed Stable } & \text { Presumed Stable } \\ \text { Presumed Stable } & \text { Presumed Stable } \\ \text { Presumed Stable } & \text { Presumed Stable }\end{array}$

FWC

FWC, MCF

FWC

MCF, RMM

MCS

$\mathrm{MCF}$

FWC

MCF, SUA

MCS, RMM

FWC, MCF, MCS

SUA

S3, BSSC

FWC, MCF

RMM

MCF, RMM

AQU, RMM

FWC, RMM 
Barn Swallow (Hirundo rustica)

Mountain Chickadee

(Poecile gambeli)

Chestnut-backed Chickadee

(Poecile rufescens)

Oak Titmouse

(Baeolophus inornatus)

Bushtit

(Psaltriparus minimus)

Red-breasted Nuthatch

(Sitta canadensis)

White-breasted Nuthatch

(Sitta carolinensis)

Pygmy Nuthatch

(Sitta pygmaea)

Brown Creeper

(Certhia americana)

Rock Wren

(Salpinctes obsoletus)

Canyon Wren

(Catherpes mexicanus)

Bewick's Wren

(Thryomanes bewickii)

House Wren

(Troglodytes aedon)

Pacific Wren

(Troglodytes pacificus)

Marsh Wren

(Cistothorus palustris)

Blue-gray Gnatcatcher

(Polioptila caerulea)

American Dipper

(Cinclus mexicanus)

\begin{tabular}{|c|c|c|c|}
\hline Presumed Stable & Presumed Stable & & FWC, RMM \\
\hline Presumed Stable & Presumed Stable & & $\mathrm{MCF}$ \\
\hline Presumed Stable & Presumed Stable & & FWC \\
\hline Presumed Stable & Presumed Stable & S3 & FWC \\
\hline Increase Likely & Presumed Stable & & FWC, MCS \\
\hline Presumed Stable & Presumed Stable & & $\mathrm{MCF}$ \\
\hline Presumed Stable & Presumed Stable & & FWC, MCF, SUA \\
\hline Presumed Stable & Presumed Stable & & $\mathrm{MCF}$ \\
\hline Increase Likely & Increase Likely & & $\mathrm{MCF}$ \\
\hline Presumed Stable & Presumed Stable & & FWC, MCF, SUA \\
\hline Presumed Stable & Presumed Stable & & FWC, MCS \\
\hline Increase Likely & Presumed Stable & & FWC, MCS \\
\hline Increase Likely & Increase Likely & & FWC, MCS, RMM \\
\hline Presumed Stable & Presumed Stable & & $\mathrm{MCF}$ \\
\hline Presumed Stable & Presumed Stable & & RMM \\
\hline Increase Likely & Presumed Stable & & FWC \\
\hline oderately Vulnerable & Presumed Stable & & AQU \\
\hline
\end{tabular}


Golden-crowned Kinglet

(Regulus satrapa)

Ruby-crowned Kinglet

(Regulus calendula)

Wrentit

(Chamaea fasciata)

Western Bluebird

(Sialia mexicana)

Mountain Bluebird

(Sialia currucoides)

Townsend's Solitaire

(Myadestes townsendi)

Swainson's Thrush

(Catharus ustulatus)

Hermit Thrush

(Catharus guttatus)

American Robin

(Turdus migratorius)

California Thrasher

(Toxostoma redivivum)

European Starling

(Sturnus vulgaris)

American Pipit

(Anthus rubescens)

Phainopepla

(Phainopepla nitens)

Orange-crowned Warbler

(Oreothlypis celata)

Nashville Warbler

(Oreothlypis ruficapilla)

MacGillivray's Warbler

(Geothlypis tolmiei)

\begin{tabular}{|c|c|c|c|}
\hline Presumed Stable & Presumed Stable & & $\mathrm{MCF}$ \\
\hline Presumed Stable & Presumed Stable & & $\mathrm{MCF}$ \\
\hline Presumed Stable & Presumed Stable & & FWC \\
\hline Increase Likely & Increase Likely & & FWC \\
\hline Presumed Stable & Presumed Stable & & MCS, SUA \\
\hline Presumed Stable & Presumed Stable & & $\mathrm{MCF}$ \\
\hline Moderately Vulnerable & Moderately Vulnerable & $\mathrm{S} 4$ & RMM \\
\hline Presumed Stable & Presumed Stable & & $\mathrm{MCF}$ \\
\hline Increase Likely & Increase Likely & & FWC, MCF, RMM \\
\hline Increase Likely & Increase Likely & & FWC \\
\hline Increase Likely & Increase Likely & & FWC, RMM \\
\hline Moderately Vulnerable & Moderately Vulnerable & $\mathrm{S} 2$ & SUA \\
\hline Presumed Stable & Presumed Stable & $\mathrm{S} 4$ & FWC \\
\hline Increase Likely & Increase Likely & & FWC, RMM \\
\hline Presumed Stable & Presumed Stable & & FWC, MCF \\
\hline Presumed Stable & Presumed Stable & & RMM \\
\hline
\end{tabular}


Common Yellowthroat

(Geothlypis trichas)

Yellow Warbler

(Setophaga petechia)

Yellow-rumped Warbler

(Setophaga coronata)

Black-throated Gray Warbler

(Setophaga nigrescens)

Hermit Warbler

(Setophaga occidentalis)

Wilson's Warbler

(Cardellina pusilla)

Green-tailed Towhee

(Pipilo chlorurus)

Spotted Towhee

(Pipilo maculatus)

Rufous-crowned Sparrow

(Aimophila ruficeps)

California Towhee

(Melozone crissalis)

Chipping Sparrow

(Spizella passerina)

Brewer's Sparrow

(Spizella breweri)

Black-chinned Sparrow

(Spizella atrogularis)

Vesper Sparrow

(Pooecetes gramineus)

Lark Sparrow

(Chondestes grammacus)

Sage Sparrow

(Amphispiza belli)

\begin{tabular}{|c|c|c|c|}
\hline Presumed Stable & Presumed Stable & & RMM \\
\hline Presumed Stable & Presumed Stable & S3, BSSC & MCS, RMM \\
\hline Presumed Stable & Presumed Stable & & $\mathrm{MCF}$ \\
\hline Presumed Stable & Presumed Stable & & FWC, MCF, MCS \\
\hline Presumed Stable & Presumed Stable & S3 & $\mathrm{MCF}$ \\
\hline Presumed Stable & Presumed Stable & & $\mathrm{RMM}$ \\
\hline Presumed Stable & Presumed Stable & & MCS \\
\hline Increase Likely & Increase Likely & & FWC, MCS \\
\hline Increase Likely & Presumed Stable & & FWC \\
\hline Increase Likely & Increase Likely & & FWC \\
\hline Increase Likely & Increase Likely & S3 & FWC, MCF, RMM \\
\hline Presumed Stable & Presumed Stable & S3 & MCS \\
\hline Increase Likely & Increase Likely & S3 & FWC \\
\hline Presumed Stable & Presumed Stable & & MCS \\
\hline Presumed Stable & Presumed Stable & & FWC \\
\hline Presumed Stable & Presumed Stable & S2 & FWC, MCS \\
\hline
\end{tabular}


Savannah Sparrow

(Passerculus sandwichensis)

Fox Sparrow

(Passerella iliaca)

Song Sparrow

(Melospiza melodia)

Lincoln's Sparrow

(Melospiza lincolnii)

White-crowned Sparrow

(Zonotrichia leucophrys)

Dark-eyed Junco

(Junco hyemalis)

Western Tanager

(Piranga ludoviciana)

Black-headed Grosbeak

(Pheucticus melanocephalus)

Lazuli Bunting

(Passerina amoena)

Red-winged Blackbird

(Agelaius phoeniceus)

Western Meadowlark

(Sturnella neglecta)

Yellow-headed Blackbird

(Xanthocep. xanthocephalus)

Brewer's Blackbird

(Euphagus cyanocephalus)

Brown-headed Cowbird

(Molothrus ater)

Bullock's Oriole

(Icterus bullockii)

Gray-crowned Rosy-Finch

(Leucosticte tephrocotis)

$\begin{array}{lc}\text { Increase Likely } & \text { Increase Likely } \\ \text { Increase Likely } & \text { Increase Likely } \\ \text { Increase Likely } & \text { Increase Likely } \\ \text { Presumed Stable } & \text { Presumed Stable } \\ \text { Presumed Stable } & \text { Presumed Stable } \\ \text { Presumed Stable } & \text { Presumed Stable } \\ \text { Presumed Stable } & \text { Presumed Stable } \\ \text { Presumed Stable } & \text { Presumed Stable } \\ \text { Increase Likely } & \text { Increase Likely } \\ \text { Presumed Stable } & \text { Presumed Stable } \\ \text { Presumed Stable } & \text { Presumed Stable } \\ \text { Presumed Stable } & \text { Presumed Stable } \\ \text { Increase Likely } & \text { Increase Likely } \\ \text { Increase Likely } & \text { Increase Likely } \\ \text { oderately Vulnerable } & \text { Moderately Vulnerable }\end{array}$

MCS

MCF, MCS

RMM

RMM

RMM, SUA

MCF, SUA

$\mathrm{MCF}$

FWC, RMM

FWC, RMM

RMM

FWC, MCS, RMM

S3, BSSC

RMM

RMM

FWC, RMM

FWC, RMM

SUA 
Pine Grosbeak

(Pinicola enucleator)

Purple Finch

(Carpodacus purpureus)

Cassin's Finch

(Carpodacus cassinii)

House Finch

(Carpodacus mexicanus)

Red Crossbill

(Loxia curvirostra)

Pine Siskin

(Spinus pinus)

Lesser Goldfinch

(Spinus psaltria)

Lawrence's Goldfinch

(Spinus lawrencei)

Evening Grosbeak

(Coccothraustes vespertinus)

House Sparrow

(Passer domesticus)

$\begin{array}{ccc}\text { Moderately Vulnerable } & \text { Moderately Vulnerable } & \text { MCF } \\ \text { Presumed Stable } & \text { Presumed Stable } & \text { FWC, MCF } \\ \text { Presumed Stable } & \text { Presumed Stable } & \text { MCF, SUA } \\ \text { Increase Likely } & \text { Increase Likely } & \text { FWC } \\ \text { Presumed Stable } & \text { Presumed Stable } & \text { MCF } \\ \text { Presumed Stable } & \text { Presumed Stable } & \text { MCF, SUA } \\ \text { Increase Likely } & \text { Presumed Stable } & \text { FWC, RMM } \\ \text { Increase Likely } & \text { Presumed Stable } & \text { S3 } \\ \text { Moderately Vulnerable } & \text { Moderately Vulnerable } & \text { FWC } \\ \text { Increase Likely } & \text { Presumed Stable } & \text { MCF }\end{array}$

†S1-S4 indicate California State Rarity and Endangerment rankings other than 'secure' ( $\mathrm{S} 1$ = critically imperiled, S2 = imperiled, S3 = vulnerable, S4 = apparently secure (CDFG 2011a); T and E indicate species listed as Threatened (T) or Endangered (E) in California (CDFG 2011b); BSSC indicates California Bird Species of Special Concern (Shuford and Gardali 2008).

‘Species’ primary breeding habitats classified as foothill woodlands and foothill chaparral (FWC; 67 species); montane conifer forests (MCF; 62 species); montane chaparral and sagebrush (MCS; 28 species); aquatic habitats including rivers, ponds, and lakes (AQU; 15 species); riparian vegetation, meadows, and marshes (RMM; 52 species); and/or subalpine and alpine habitats (SUA; 13 species).

${ }^{\S}$ Rufous Hummingbird is the only species we assessed that does not actually breed in the Sierra Nevada, though it becomes the most common hummingbird species in the region when it migrates through during the summer when most Sierra Nevada bird species are still breeding. 


\section{Appendix 2.}

Summary Rationale for Scoring Climate Change Vulnerability of Sierra Nevada Bird Species with NatureServe's Climate Change Vulnerability Index (CCVI).

Here we present detailed methodology and references for the application of CCVI methodology (Young et al. 2009, 2011, 2012) to assessing vulnerability of birds in the Sierra Nevada.

\section{General Strategy}

We assigned preliminary codes for each species for each category based on NatureServe guidelines and examples (Young et al. 2011), along with general knowledge about each species within the defined Sierra Nevada Region. Literature specific to each species, including that included in The Birds of North America (BNA) accounts (Poole 2005) was then reviewed to see whether or not preliminary codes needed to be revised. We also compared our coding strategies and codes with those of another CCVI analysis performed by the Nevada Natural Heritage Program for the state of Nevada (Young et al. 2009).

For each species, subscores or values were assigned to 24 categories located in four sections (A, B, C, and D) of the CCVI model. Code selection for each category differed, with 3-6 coding choices being available per category (Young et al. 2011). For each category we present below the specific set of choices for that category. From most to least vulnerable these choices and abbreviations for the matrix are:

Greatly Increased Vulnerability - GI

Increased Vulnerability - Inc

Slightly Increased Vulnerability - SI

Neutral - N

Slightly Decreased Vulnerability - SD

Decreased Vulnerability - Dec

Unknown (U) is also a choice that was more appropriate for some categories than others; e.g., broad categories $\mathrm{C}$ and $\mathrm{D}$ tended to get $\mathrm{U}$ codes as the default subscore whereas broad category $\mathrm{B}$ got $\mathrm{N}$ as a default subscore.

We chose to only assign one of these six subscores per species per category, as we felt that this was adequate resolution for scoring, given some subjectivity in assigning most scores. In other CCVI analyses such as the Nevada State CCVI (Young et al. 2009) more than one score could be assigned to a species, such as "Inc.-SI."

The following sections detail subscoring methods, strategy, and techniques for each category as related to the Sierra Nevada CCVI:

\section{A. Exposure to Local Climate Change}

Coding is not performed; rather data values are directly entered. 
From Guidelines (Young et al. 2011): This section must be completed for the Index to calculate a vulnerability score. All factors refer to ranges and populations within the assessment area. Because of the relatively coarse scale of the climate data, use extent of occurrence maps of species distributions rather than point maps of actual populations. Obtain Climate Wizard data as instructed in Box 2. For temperature, calculate or estimate the percentage of the range of the species in each of the following categories and enter the results in the corresponding boxes for temperature under Section $A$ on the Calculator. Then do the same for moisture (downloading data from http://www. natureserve.org/climatechange or viewing the map in Figure 2a), calculating or estimating the percentage of the range of the species in each of the following categories:

This section was entered by Andy Holguin of Jim Thorne of the University of California at Davis based upon results of their GIS modeling using recently updated and sophisticated modeling procedures and climate data sets for the Sierra Nevada region (Thorne et al. 2012). Climate Wizard was not used but the instructions were followed to ensure CCVI methodology remained intact and consistent. The areas for each species' range within the Sierra Nevada Region were scored based on five categories for temperature and six for moisture, each set adding up to $100 \%$ (Young et al. 2011).

To capture uncertainty inherent in climate projections, two projection models were employed, the Geophysical Fluid Dynamics Laboratory (GFDL) and Parallel Climate Model (PCM), that most accurately represent California climate in current time and provide relatively divergent future projections whose implications for California's climate have been well explored (Cayan et al. 2008). Calculations were made for summer range, winter range, and both summer and winter range combined, within our Sierra Nevada Region, from broad-scale range maps of bird species developed by Zeiner et al. (1990) and digitized and updated for some species by staff at the California Department of Fish and Game. Those for the summer range only were entered into the matrix for the Sierra Nevada CCVI analysis reported here. Data are available for the other two ranges for future analyses as needed. Calculations for two species (Black Rail and Cedar Waxwing) were not undertaken due to little or no definable summer range in the Sierra Nevada

For this analysis, data have been further downscaled and bias corrected from a subset of four of the "standard" climate scenarios provided by Cayan et al (2008); see Flint and Flint (2007) and Thorne et al (2012). This subset of downscaled standard future climate projections as well as historical data are based on the 4km PRISM climate surfaces and was created using a method developed by Flint and Flint to a 270m horizontal resolution. For the Sierra Nevada Region, we produced $270 \mathrm{~m}$ grids to represent historic and future climates from 1900 to 2100 , resulting in $6,594,862$ grid cells. We reduced the data size for distribution to 30 -year means, providing monthly blocks of variables historically for 1911-1940, 1941-1970, 1971-2000. Future climate values are based off 100 year simulations, with 2010-2039, 2040-2069, and 2070-2099 time slices produced. ASCII or ArcGRID files are available for each of the time slices.

Using a regional water balance model, the Basin Characterization Model (BCM), driven by the high resolution downscaled precipitation and temperature, Flint and Flint (2007) developed a program to calculate and portray several other derivative measures associated with water balance at the land surface. We used the BCM to produce an additional suite of variables state-wide at the $270 \mathrm{~m}$ grid scale. The following table includes variable calculations used for the Sierra Nevada CCVI: 


\begin{tabular}{|c|c|c|c|c|c|}
\hline Variable & Code & $\frac{\text { Creation }}{\text { Method }}$ & Units & Equation/model & Description \\
\hline$\frac{\text { Maximum }}{\text { Temperature }}$ & $\operatorname{tmax}$ & downscaled & $\begin{array}{l}\text { degree } \\
\mathrm{C}\end{array}$ & Model input & $\begin{array}{l}\text { The maximum monthly } \\
\text { temperature averaged } \\
\text { annually }\end{array}$ \\
\hline $\begin{array}{l}\text { Minimum } \\
\text { Temperature }\end{array}$ & $\operatorname{tmin}$ & downscaled & $\begin{array}{l}\text { degree } \\
\mathrm{C}\end{array}$ & Model input & $\begin{array}{l}\text { The minimum monthly } \\
\text { temperature averaged } \\
\text { annually }\end{array}$ \\
\hline Precipitation & ppt & downscaled & $\mathrm{mm}$ & Model input & $\begin{array}{l}\text { Total monthly } \\
\text { precipitation (rain or } \\
\text { snow) summed annually }\end{array}$ \\
\hline $\begin{array}{l}\text { Climatic Water } \\
\text { Deficit }\end{array}$ & CWD & $\mathrm{BCM}$ & $\mathrm{mm}$ & PET-AET & $\begin{array}{l}\text { Annual evaporative } \\
\text { demand that exceeds } \\
\text { available water, summed } \\
\text { annually }\end{array}$ \\
\hline
\end{tabular}

For temperature we used ${ }^{\circ} \mathrm{C}$ and converted changes in these values to calculate projected change proportions needed for the CCVI matrix, which uses ${ }^{\circ} \mathrm{F}$ (Young et al. 2011). Moisture Calculations were made based on Climate Water Deficit (CWD), which is the Annual Potential Transpiration (PET) minus Actual Transpiration (AET), as opposed to the Harmon Moisture Metric (AET:PET) used by the CCVI (Young et al. 2011). CWD tracks vegetative and other biological phenologies according to soil moisture in the Sierra Nevada Region better than the Harmon Index (Lutz et al. 2010).

Projected temperature and mosture changes were calculated for each $270 \mathrm{~m}$ grid cell and binned into five (tempertaure) or six (moisture) categories according to CCVI guidelines (Young et al. 2011). Breakpoints for each of the bins were carefully calculated to equate with those of the guidelines as closely as possible given the different temperature and moisture units employed. The percent of each species range which fell into the different categories was entered into the eleven columns of the CCVI matrix. These calculations were performed twice, once each for GFDL and PCM climate projections.

\section{B1. Indirect Exposure Climate Change; Exposure to Sea Level Rise}

Available CCVI Codes (Young et al. 2011) are: GV, Inc, SI, N, and SD.

Because the Sierra Nevada Region includes no ocean coastline, no species will be affected by a 0.5-1.0 $\mathrm{m}$ rise in sea level. Following the guidelines, $\mathrm{N}$ has been entered for all species and no specific adjustments will be necessary. This strategy was followed for the Nevada State CCVI (Young et al. 2009).

\section{B2a. Indirect Exposure; Distribution Relative to Natural Barriers}

Available CCVI Codes (Young et al. 2011) are: GI, Inc SI, and N. 
From guidelines (Young et al. 2011): "This factor assesses the degree to which natural (e.g., topographic, geographic, ecological) or anthropogenic barriers limit a species' ability to shift its range in response to climate change. Barriers are defined here as features or areas that completely or almost completely prevent movement or dispersal of the species (currently and for the foreseeable future)."

This factor appears to apply most to sedentary or aquatic plant, invertebrate, amphibian, or fish species that are unable to disperse through unfavorable habitats such as agricultural lands, over dams along rivers, away from natural springs, etc. For birds the guidelines state:

Note that no barriers exist for most temperate-zone bird species that simply fly over or around potential obstructions.

For natural barriers the guidelines state:

Examples of features that may function as natural barriers for various species include: upland habitat (i.e., absence of aquatic stream, lake, or pond habitat) is a barrier for fishes (but not for semiaquatic or amphibious species that may occupy the same body of water); high mountain ranges (especially those that extend west-east) are a barrier for many lowland plants and nonvolant lowland animals; warm lowlands are a barrier for some alpine species such as American pika (Ochotona princeps) but not for elk (Cervus canadensis) or American pipit (Anthus rubescens); large expanses of water are barriers for pocket gophers and many other small terrestrial animals (but not for many volant species, or for plant species that are dispersed by wide-ranging birds, or for species that readily swim between land areas if the distance is not too great); a high waterfall is a barrier for fishes (but not for American dippers [Cinclus mexicanus] or gartersnakes [Thamnophis spp.] that occur along the same stream).

The Nevada State CCVI (Young et al. 2009) assigned N to all bird species except Sooty Grouse, which was scored Inc-SI because it inhabits isolated forested habitats in Nevada separated by broad expanses of desert/sage habitats across which it is incapable of traversing.

Three species in the Sierra Region are potentially incapable of crossing natural barriers: Whitetailed Ptarmigan, Greater Roadrunner, and Wrentit. All three are non-mobile species that occur in selected and isolated habitats within the region, and are seldom or never observed in other habitats during dispersal. For these three species we assigned preliminary codes of SI and codes of $\mathrm{N}$ to all remaining species. However, after reviewing category $\mathrm{C} 1$ (ability to disperse within habitats) we decided that other non-dispersing species should be placed here rather than in that category.

The language of note from the guidelines is: "If a feature or area does not completely or almost completely prevent dispersal or movement then it is categorized here as unsuitable or suitable habitat, and the dispersal/movement of individuals across that feature or area is assessed under Factor C1 (Dispersal and Movements). In most cases, unsuitable habitat is habitat through which propagules or individuals may move but that does not support reproduction or long-term survival."

We decided that some resident species particular to certain habitats are "completely or almost completely" prevented from moving across certain other habitats, primarily because they are never encountered in these habitats, and that they should be better scored here than under Factor $\mathrm{C} 1$. This is particularly the case for forest species traversing open habitats and vice versa. We interpreted Factor $\mathrm{C} 1$ more as ability to disperse within habitats that are either appropriate for breeding or are easily traversed by the species during dispersal. 
We thus re-assigned Inc to the three species mentioned above and gave subscore SI to 21 species that are less-capable of traversing unoccupied habitats: Mountain Quail, California Quail, Sooty Grouse, Western Screech-Owl, Northern Pygmy-Owl, Spotted Owl, Great Gray Owl, Nuttall's Woodpecker, Downy Woodpecker, Hairy Woodpecker, White-headed Woodpecker, Pileated Woodpecker, Chestnut-backed Chickadee, Oak Titmouse, Bushtit, White-breasted Nuthatch, Pygmy Nuthatch, California Thrasher, Rufous-crowned Sparrow, California Towhee, and Pine Grosbeak.

Borderline cases that we decided to score as N rather than SI include Western Srcub-Jay. Steller's Jay, Mountain Chickadee, Bewick's Wren, and Gray-crowned Rosy-Finch.

\section{B2b. Indirect Exposure; Distribution Relative to Anthropogenic Barriers}

Available CCVI Codes (Young et al. 2011) are: GI, Inc SI, and N

From guidelines (Young et al. 2011): "This factor assesses the degree to which natural (e.g., topographic, geographic, ecological) or anthropogenic barriers limit a species' ability to shift its range in response to climate change. Barriers are defined here as features or areas that completely or almost completely prevent movement or dispersal of the species (currently and for the foreseeable future)."

This factor appears to apply most to sedentary or aquatic plant, invertebrate, amphibian, or fish species that are unable to disperse through unfavorable habitats such as agricultural lands, over dams along rivers, away from natural springs, etc. For birds the guidelines say:

Note that no barriers exist for most temperate-zone bird species that simply fly over or around potential obstructions.

For anthropogenic barriers the guidelines say:

Examples of features that may function as anthropogenic barriers include: large areas of intensive urban or agricultural development...; waters subject to chronic chemical ...or...thermal pollution; dams without fish passage facilities...; tortoise-proof fencing...

See notes under B2a regarding natural barriers. The three species we considered more subject to natural barriers (White-tailed Ptarmigan, Greater Roadrunner, and Wrentit) are not restricted by anthropogenic barriers so we have coded all bird species with N. The Nevada State CCVI (Young et al. 2009) assigned $\mathrm{N}$ to all bird species as well.

\section{B3. Indirect Exposure; Predicted Impact of Land Use Changes Resulting from Human Responses to Climate Change}

Available CCVI Codes (Young et al. 2011) are: Inc, SI, N, SD, and Dec.

The purpose here is to assess the impacts of anthropogenic projects that will result from climatechange policies such as (from guidelines): "plantations for carbon offsets, new seawalls in response to sea level rise, and renewable energy projects such as wind-farms, solar arrays, or biofuels production."

The guidelines further note: 
This factor is NOT intended to capture habitat loss or destruction due to on-going human activities, as these should already be included in existing conservation status ranks. Include only new activities related directly to climate change mitigation here. There is much uncertainty about the types of mitigation action that are likely to threaten habitats and species. Remember that multiple categories can be checked for each factor to capture uncertainty. As federal and state climate change legislation is enacted, some of the mitigation directions (and associated threats or benefits to species) will become clearer.

The guidelines give six examples leading to a code of Inc (Increased vulnerability), the most vulnerable code for this column. The factor with greatest potential effect for birds is wind farms:

Bird and bat species whose migratory routes, foraging territory, or lekking sites include existing and/or suitable wind farm sites. If numerous wind farms already exist along the species' migratory route, negative impacts have been found in relevant studies; if such studies exist but negative impacts have not been found, a lesser impact category may be appropriate.

Other factors that may affect birds in the Sierra Nevada include reforestation or afforestation in response to climate change policies, conversion of natural habitats to farmlands for biofuel production, and damming of rivers for hydropower.

Note that a big distinction between Inc and SI (or Dec and SD) codes (Young et al. 2011) is that mitigation or renewable-energy projects "are likely to occur" (Inc or Dec) or "may possibly occur" (SI or SD).

The Nevada State CCVI (Young et al. 2009) assigned codes of Inc, SI, and N for birds. Their strategy was to assign most open-country migratory species as Inc due to potential impacts of planned wind-farm and solar-array development, while many sedentary forest birds received $\mathrm{N}$. Only a few species received SI because planned projects in the ranges of these species were only possibly to occur.

In the Sierra Nevada Region these threats are not as severe as they are for the state of Nevada. Solar-array development and conversion to farmlands are factors that should have little if any impact in the Sierra Nevada .

There are few or no current plans for wind-farm development directly within the Sierra Nevada Region. The closest plans are for the Tehachapi region, Kern County, just outside of the southern end of the Sierra Nevada region. However, the potential exists as there are areas of high winds in the Sierra Nevada region in which solar-energy watchers are considering (e.g., see http://www.energy.ca.gov/maps/renewable/wind potential.html). However, roads would need to be widened to accommodate wind-farm development in mountainous areas so it seems unlikely. Thus, in the absence of current viable plans for wind-farm development in the Sierra Nevada, We have not applied Inc to any species based on potential hazards of wind farms.

Due to possible wind-farm development in the future we assigned SI to 27 species of raptors and other aerial foraging species known to be impacted by turbines: Turkey Vulture, Northern Harrier, Sharp-shinned Hawk, Cooper's Hawk, Northern Goshawk, Red-shouldered Hawk, Redtailed Hawk, Golden Eagle, American Kestrel, Peregrine Falcon, Prairie Falcon, Sandhill Crane, Barn Owl, Great Horned Owl, Long-eared Owl, Common Nighthawk, Black Swift, Vaux's Swift, White-throated Swift, Black Phoebe (see also below), Western Kingbird, Horned Lark, 
Purple Martin, Tree Swallow, Violet-green Swallow, Northern Rough-winged Swallow, and Barn Swallow. See below regarding Osprey and Bald Eagle.

Divisions between SI and N for these species seemed straight-forward and we identified no borderline species. We considered SI for American Pipit but it's breeding range, high in the Sierra Nevada, is not likely to be affected by turbine development (see above).

The only other climate-related development we could locate for the Sierra Nevada Region involves the controversial damming project (Auburn Dam) proposed along the American River southeast of Auburn, along the eastern birder of the Sierra Nevada Region (see, e.g. http://www.geoengineer.org/auburn.htm). We considered this project only "possibly" to be undertaken due to high financial and land-area costs and resistance from environmental and other groups (http://www.auburndamwatch.org/). We have thus assigned SD to three waterbird species (Bufflehead, Pied-billed Grebe, and American Coot) that might benefit from an additional reservoir, and SI to one species (American Dipper) that would be impacted by conversion of river-bottom habitats to a reservoir. Two other species (Common Merganser and Spotted Sandpiper) may both benefit from a reservoir and be impacted by conversion of river bottoms since, they breed and occur in both habitats, and we retained the code $\mathrm{N}$ for these.

Black Phoebe might also be affected by river-bottom conversion but already received SI for possible turbine impacts (see above). For two aerial raptors, Osprey and Bald Eagle, we assigned code $\mathrm{N}$ because the potential benefits of a new reservoir (SD) could offset the potential impacts of potential wind-farm operations (SI).

\section{C1. Sensitivity; Dispersal and Movements}

Available CCVI Codes (Young et al. 2011) are: GI, Inc, SI, N, SD, and Dec.

From guidelines (Young et al. 2011): "This factor pertains to known or predicted dispersal or movement capacities and characteristics and ability to shift location in the absence of barriers as conditions change over time as a result of climate change. Species in which individuals exhibit substantial dispersal, readily move long distances as adults or immatures, or exhibit flexible movement patterns should be better able to track shifting climate envelopes than are species in which dispersal and movements are more limited or inflexible. This factor is assessed conservatively and pertains specifically to dispersal through unsuitable habitat, which, in most cases, is habitat through which propagules or individuals may move but that does not support reproduction or long-term survival."

This factor appears to apply most to sedentary or aquatic plant, amphibian, or fish species that are unable to disperse, even though habitats may be favorable. For birds and other migratory animals the guidelines state:

"Most migratory species will satisfy criteria for the decrease vulnerability criteria. Use their ability to shift their distribution within the assessment during the period of occupation or from one year to the next (whichever is larger) as the measure of dispersal distance."

We chose to interpret this category more as dispersal within favorable (or at least traversable) habitat and not those unable to traverse unoccupied habitats (see category B2a above). 
The Nevada State CCVI (Young et al. 2009) assigned Dec to most species and SD to a few strictly resident species such as gamebirds and Three-toed Woodpecker. They gave SD-Dec to two grouse species. They assigned Inc to California Spotted Owl, perhaps due to concern over dispersing juveniles.

We felt that all Sierra Nevada species could effectively disperse through appropriate habitats, although Wrentit stood out as the species with the least capability of crossing marginal habitats. So we assigned Wrentit code SD and gave Dec to all other species. We decided that potential concerns about dispersing in Spotted Owl did not warrant a code other than Dec in the Sierra Nevada.

\section{C2a and 2b. Sensitivity; Changes in temperature (a) and precipitation (b)}

Available CCVI Codes (Young et al. 2011) are: GI, Inc, SI, N, and SD.

From guidelines (Young et al. 2011): "This factor pertains to the breadth of temperature [or moisture] conditions, at both broad and local scales, within which a species is known to be capable of reproducing, feeding, growing, or otherwise existing. Species with narrow environmental tolerances/requirements may be more vulnerable to habitat loss from climate change than are species that thrive under diverse conditions."

This category is further broken into historical (C2ai and C2bi) and physical (C2aii and C2bii) tolerances, coding for the former of which will be based on climate-modeling results. For sensitivity to temperature the guidelines state the following:

"Current projections indicate that climate warming will be nearly pervasive in North America over the next several decades. Species associated with cool or cold conditions likely will experience a reduction in habitat extent or quality and may experience declines in distribution or abundance within a given assessment area. This factor assesses the degree to which a species is restricted to relatively cool or cold above-ground terrestrial or aquatic environments that are thought to be vulnerable to loss or significant reduction as a result of climate change. Species that depend on these cool/cold environments include (but may not be limited to) those that occur in the assessment area's highest elevational zones, northernmost areas, or the coldest waters. The restriction to these relatively cool environments may be permanent or seasonal."

For sensitivity to temperature the guidelines state the following:

"This factor pertains to a species' dependence on a narrowly defined precipitation/hydrologic regime, including strongly seasonal precipitation patterns and/or specific aquatic/wetland habitats (e.g., certain springs $^{*}$, vernal pools, seeps, seasonal standing or flowing water) or localized moisture conditions that may be highly vulnerable to loss or reduction with climate change. Dependence may be permanent or seasonal...Species nesting on islands in lakes, reservoirs, and/or wetlands that prevent predator access can be scored here to the extent that a changed hydrological regime may influence the availability of these predator-free breeding sites (for example, birds nesting on islands to avoid predation by mammals). If a species is dependent on aquatic/wetland habitats that are actively managed to maintain a particular hydrology, consider whether this management would be sufficient to ameliorate projected climate change impacts (and, if so, score as Neutral). Many habitats in the U.S. are predicted to experience net drying (see annual and seasonal Hamon AET:PET moisture metric maps in Figure 2 or as downloadable GIS files at http://www.natureserve.org/climatechange), even in areas where precipitation is predicted to increase. Consider the direction, strength, and seasonality of moisture change in ranking this factor, along with the level of dependence of the species on particular hydrologic conditions." 


\section{C2ai. Sensitivity; Changes in temperature; Historical thermal niche (exposure to past variations in temperature)}

From guidelines (Young et al. 2011): This factor measures large-scale temperature variation that a species has experienced in recent historical times (i.e., the past 50 years), as approximated by mean seasonal temperature variation (difference between highest mean monthly maximum temperature and lowest mean monthly minimum temperature) for occupied cells within the assessment area. It is a proxy for species' temperature tolerance at a broad scale. This factor may be evaluated by comparing the species range with the Annual Temperature Variation map 1951-2006 (Figure 3) or calculated using GIS data downloaded from NatureServe (http://www. natureserve.org/climatechange). For aquatic species, follow the same procedure as for terrestrial species, since this factor measures broad regional patterns. Use the annual map for both resident and migratory species. Although migratory species are not physically present to experience temperature variations, they nonetheless are affected by these variations through effects on food supply and habitat availability.

Calculations were made based on yearly temperatures (monthly mean minimums and maximums) from all months (January-December), including for species not present in the Sierra Nevada region for all months of the year. Thus, it would typically involve the July monthly maximum minus the January mean monthly minimum for each $270 \mathrm{~m}$ cel within the defined range. For each species, calculations were made for summer range, winter range, and combined summer and winter range from the broad-scale maps originally designed by Zeiner et al. (1990), and those for summer range were entered (see Section A, above). Following the guidelines (Young et al. 2011), ranges were divided into five categories based on historic temperature variance that each species has tolerated, ranging from: GI $<20.8$ degrees $\mathrm{C}$, Inc 20.8-26.3, SI 26.3-31.8, N 31.8-43.0, and SD >43.0 degrees. Scores are based on the highest category for which at least $10 \%$ of the range is included.

Calculations for this section were made by Andy Holguin and Jim Thorne of University of California based upon results of GIS modeling (see Section A, above). The proportion of each species' range within the Sierra Nevada Region was scored based on these five categories for temperature, adding up to $100 \%$ of the range. Beginning with $\%$ of the range showing $<20.8$ degree variation (none in this case) we cumulatively added up percentages for Inc, SI, N, and SD and when $10 \%$ of the range was included we assigned the appropriate subscore.

This method resulted in a score of SI for all but 9 species, which received $\mathrm{N}$. The species receiving $\mathrm{N}$ were typically species with breeding ranges on the eastern slope of the Sierra Nevada, which experience broader temperature ranges. These nine species were: Northern Harrier, Sandhill Crane, Sora, Wilson's Snipe, Black Swift, Gray Flycatcher, Black-billed Magpie, Savannah Sparrow, and Vesper Sparrow.

\section{C2aii. Sensitivity; Changes in temperature; Physiological Thermal Niche}

Scoring was based on how restricted species are in summer to the coldest climates within the region. Note that we interpreted this based on regions in which the species breeds, and not on the actual physical tolerance of the individuals to differing thermal regimes.

The Nevada State CCVI (Young et al. 2009) took this approach as well, scoring most species as $\mathrm{N}$ and a few with more vulnerable codes. Black Rosy-Finch was the only species to be assigned 
GI and Gray-crowned Rosy Finch the only one to be assigned Inc. Greater Sage Grouse, Southwestern Willow Flycatcher, and Yellow-billed Cuckoo received SI, for the latter two species because riparian habitats may occur at higher elevations and be lost with warming.

In the Sierra Nevada Region we followed a strategy of assigning species restricted to alpine and other high-elevation habitats GI, most as N, and those restricted to the lowest elevations that could expand with warming SD, with Inc and SI used for species between GI and N. For many species we based our codes directly on the elevational ranges recorded in either Yosemite or Sequoia National Parks by Siegel et al. (2011): generally, GI to species found (breeding or as residents) in ranges restricted to $>2750 \mathrm{~m}$, Inc to those $>2300 \mathrm{~m}$, and SI to those $>1750 \mathrm{~m}$. When a species was not covered by Siegel et al., we used the information present in Gaines (1992) and other sources. We assigned the following vulnerable codes to species based on high-elevational ranges:

White-tailed Ptarmigan - GI

Sooty Grouse - SI

Common Snipe - SI

Rufous Hummingbird - Inc

Williamson's Sapsucker - Inc

Olive-sided Flycatcher - SI

Clark's Nutcracker - Inc

Horned Lark - GI

Ruby-crowned Kinglet - Inc

Mountain Bluebird - Inc

Hermit Thrush - SI

American Pipit - GI

White-crowned Sparrow - Inc

Yellow-headed Blackbird - SI

Gray-crowned Rosy-Finch - GI

Pine Grosbeak - Inc

Cassin's Finch - SI

Evening Grosbeak - SI

The following were given SD because their restricted ranges in lower elevations within the Sierra Nevada Region could expand with temperature increases. These generally were found in ranges restricted to $<1750 \mathrm{~m}$ in Yosemite or Sierra Kings Canyon NPs in Siegel et al. (2011) or in Gaines (1992):

California Quail

Red-shouldered Hawk

Yellow-billed Cuckoo

Greater Roadrunner

Western Screech-Owl

Black-chinned Hummingbird

Acorn Woodpecker

Nuttall's Woodpecker 
Ash-throated Flycatcher

Western Kingbird

Hutton's Vireo

Northern Rough-winged Swallow

Western Scrub-Jay

Chestnut-backed Chickadee

Oak Titmouse

Blue-gray Gnatcatcher

California Thrasher

Phainopepla

Rufous-crowned Sparrow

California Towhee

Black-chinned Sparrow

Lark Sparrow

Sage Sparrow

Bullock's Oriole

Lawrence's Goldfinch

The remaining species were assigned code $\mathrm{N}$.

\section{C2bi. Sensitivity; Changes in precipitation; Historical hydrological niche (exposure to past variations in precipitation)}

From guidelines (Young et al. 2011): This factor measures large-scale precipitation variation that a species has experienced in recent historical times (i.e., the past 50 years), as approximated by mean annual precipitation variation across occupied cells within the assessment area. Overlay the species' range on the Climate Wizard mean annual precipitation map 1951-2006 (see also Figure 4). Subtract the lowest pixel value from the highest value to assess this factor. Use the extreme pixel values for this calculation. Use annual data for migratory species, as this measure reflects the precipitation regime of the ecosystem as a whole.

Calculations were made for each $270 \mathrm{~m}$ grid cel based on precipitation data (annual mean rainfall in $\mathrm{mm}$ ). "Outliers" were first removed before calculations were performed following instructions on the final pages of guidelines (Young et al. 2011: 57-58; see below). For each species calculations were made for summer range, winter range, and combined summer and winter range from the broad-scale maps originally designed by Zeiner et al. (1990), and those for summer range were entered (see Section A, above). Following the guidelines (Young et al. 2011), ranges were divided into five categories based on historic moisture variance that each species has tolerated, ranging from: GI < $100 \mathrm{~mm}$, Inc 100-254, SI 255-508, N 509-1016, and SD >1016 mm of rainfall. Scores are based on the highest category for which at least $10 \%$ of the range is included.

Calculations for this section were made by Andy Holguin and Jim Thorne of University of California based upon results of GIS modeling (see Section A, above). The proportion of each species' range within the Sierra Nevada Region was scored based on these five categories for temperature, adding up to $100 \%$ of the range. Beginning with $\%$ of the range showing $<100 \mathrm{~mm}$ precipitation (none in this case) we cumulatively added up percentages for Inc, SI, N, and SD and when $10 \%$ of the range was included we assigned the appropriate subscore. 
We considered various outlier scenarios. Without excluding outliers the same model procedure resulted in SD for all but 5 species (including White-tailed Ptarmigan and Yellow-billed Cuckoo), which previously received N. We examined ranges and histograms for the 24 species whose codes were affected by the elimination of outliers and found no reasons to be concerned. Birds in the Sierra Nevada region come up with very conservative (low-vulnerability) coding in the CCVI due to two factors: 1) the relatively high range in precipitaion regimes in the Sierra Nevada as compared with other sections of North America and 2) the higher tolerance of birds for different precipitaion scenarios as compared to other organisms such as plants and aquatic animals. We continued to use the above codes, excluding outliers following the guidelines.

\title{
C2bii. Sensitivity; Changes in precipitation; Physological hydrological niche
}

We assigned scores depending on whether it is predicted to become dryer or wetter in the region based on climate change. The guidelines further state for species to be ranked the most vulnerable code (GI) they should:

\begin{abstract}
"Completely or almost completely (>90\% of occurrences or range) dependent on a specific aquatic/wetland habitat or localized moisture regime that is highly vulnerable to loss or reduction with climate change AND the expected direction of moisture change (drier or wetter) is likely to reduce the species' distribution, abundance, or habitat quality. If this second condition is not met (e.g., species dependent on springs tied to a regional aquifer that would not be expected to change significantly with climate change), the species should be scored as Neutral. Examples for Greatly Increase include certain spring-dependent fishes, ephemeral pooldependent branchiopods, and plants that are exclusively or very strongly associated with localized moist microsites (e.g., "hanging gardens" in arid landscapes)."
\end{abstract}

The Nevada State CCVI (Young et al. 2009) gave a broad range of codes which appeared to assume drying in most or all of the region. GI was given to only one species, Northern Pintail. All other waterbirds received Inc (most) or SI. SI was also given to landbirds dependent on wetter habitats such as riparian. $\mathrm{N}$ was given to most dry forest specie, and SD was not given. We followed this approach for the Sierra Nevada.

GI was given to seven species that rely entirely (>90\%) on standing pools or marshes: Piedbilled Grebe, Black Rail, Virginia Rail, Sora, American Coot, Common Snipe, and Black Tern.

We assigned Inc to all other waterbird species and those landbird species dependent on water or highly riparian situations: Wood Duck, Mallard, Harlequin Duck, Bufflehead, Common Merganser, Great Blue Heron, Osprey, Bald Eagle, Sandhill Crane, Killdeer, Spotted Sandpiper, Belted Kingfisher, Marsh Wren, American Dipper, Red-winged Blackbird, Yellow-headed Blackbird

We assigned SI to some landbird species found in moister habitats: Northern Harrier, Redshouldered Hawk, Peregrine Falcon, Black Swift, Downy Woodpecker, Willow Flycatcher, Black Phoebe, Tree Swallow, Northern Rough-winged Swallow, Pacific Wren, Swainson's Thrush, American Pipit, Yellow Warbler, Common Yellowthroat, Wilson's Warbler, Greentailed Towhee, Lincoln's Sparrow, Purple Finch 
We assigned SD to species reliant on dryer habitats within the region: Cooper's Hawk, Golden Eagle, Prairie Falcon, Greater Roadrunner, Black-chinned Hummingbird, Gray Flycatcher, Ashthroated Flycatcher, Pinyon Jay, Canyon Wren, California Thrasher, Rufous-crowned Sparrow, Black-chinned Sparrow, House Finch, and Lawrence's Goldfinch

We assigned $\mathrm{N}$ to the remaining species.

\section{C2c. Sensitivity; Dependence on specific disturbance regime likely to be impacted by climate change}

Available CCVI Codes (Young et al. 2011) are: Inc, SI, N, and SD.

From guidelines (Young et al. 2011): "This factor pertains to a species' response to specific disturbance regimes such as fires, floods, severe winds, pathogen outbreaks, or similar events. It includes disturbances that impact species directly as well as those that impact species via abiotic aspects of habitat quality. For example, changes in flood and fire frequency/intensity may cause changes in water turbidity, silt levels, and chemistry, thus impacting aquatic species sensitive to these aspects of water quality. The potential impacts of altered disturbance regimes on species that require specific river features created by peak flows should also be considered here; for example, some fish require floodplain wetlands for larval/juvenile development or high peak flows to renew suitable spawning habitat. Use care when estimating the most likely effects of increased fires; in many ecosystems, while a small increase in fire frequency might be beneficial, a greatly increased fire frequency could result in complete habitat destruction. Finally, be sure to also consider species that benefit from a lack of disturbance and may suffer due to disturbance increases when scoring this factor. For a map of modeled future fire regime, see Figure 2 in Krawchuk et al. (2009, available:

http://www.plosone.org/article/info\%3Adoi\%2F10.1371\%2Fjournal.pone.0005102)."

Modeled results from the above website (Krawchuk et al. 2009, Figure S5) shows that predictions for changes in fire frequency in the Sierra Nevada Region are more-or-less neutral or show that slightly decreased levels of fire frequency for the years 2040-2069 (encompassing our target year of 2050):
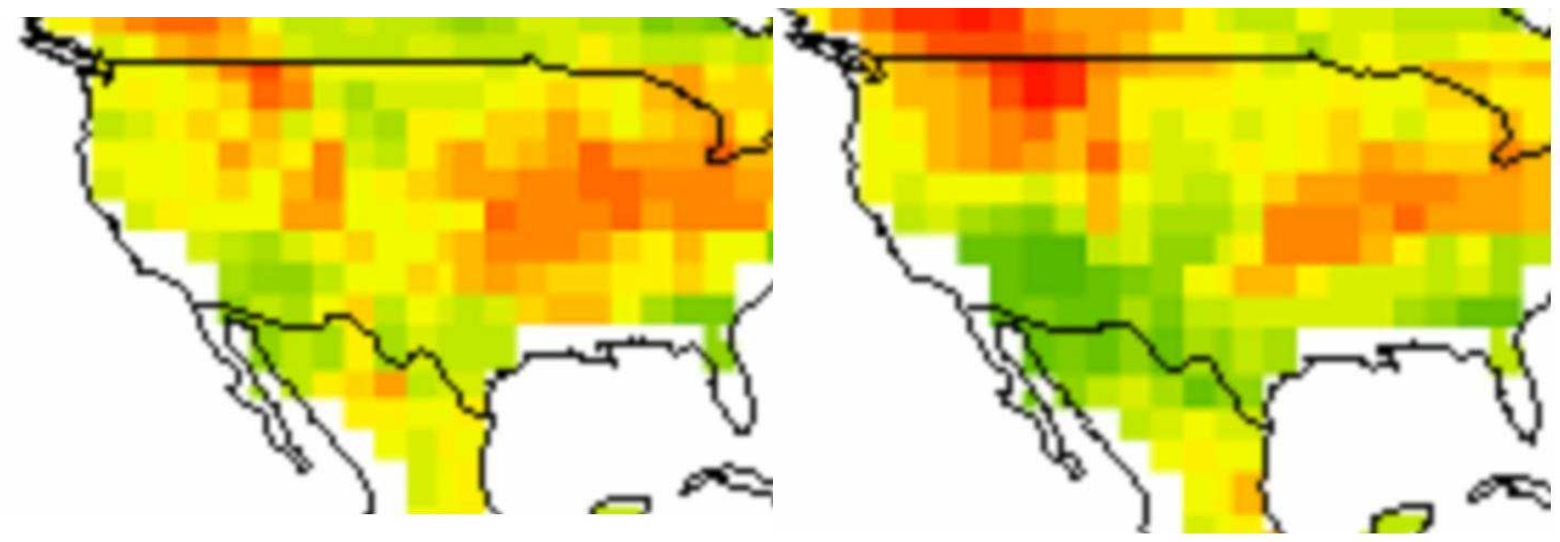

From figure S5 of Krawchuk et al. (2009) predicting change in fire frequencies in 2040-2069 based on predicted models for global climate change. Left image above ( $\mathrm{B}$ in figure) adds a vegetation component to the model whereas right image (E) has no vegetation component. Red predicts higher fire frequency, green predicts lower frequency, and yellow is neutral. 
A problem with this modeling analysis is that it is based on data from North America as a whole, and several Sierra specific projections (Miller et al. 2009; Westerling et al. 2011) expect fires to increase in coming years due to drying and decreased snowmelt. We believe that these Sierraspecific reports should be weighted more heavily in our choices than the nationally based Krawchuk et al. model. Thus, it would appear that rankings should reflect increased fire frequency in the Sierra Nevada based on effects of climate change.

Given this, in examples for code SD, the guidelines state: "For example, if climate change increases the frequency of fires, black-backed woodpeckers may benefit due to increased availability of foraging habitat (burned-over forests that become infested with beetles)." Since fire frequency is predicted to increase, if anything, we believed it appropriate to give Black-backed Woodpecker and other fire-dependent species decreased vulnerability codes (SD and Dec) based on these predictions. Likewise, species that could be harmed by fires, including many forest species, should receive increased vulnerability codes (GI, Inc, and SI).

The Nevada State CCVI (Young et al. 2009) followed this strategy as well, assigning N to most birds but gave coding for increased or decreased vulnerability based on predicted increased fire frequency with global climate change; for example, SD was assigned to fire specialists or those benefiting from fire (Black-backed and other woodpeckers and Olive-sided Flycatcher), and SI or Inc was assigned to species whose habitats would be affected by fire (sage-brush specialists, some coniferous-forest species).

Steel et al. (2010), based primarily on Smucker et al. (2005) and Fontaine et al. (2009), have assessed the effects of fire and fire predictions in the Sierra Nevada Region. We have thus used the "Altered Fire regimes" column of Table 10 of Steel et al. to assign subscores to species based on sensitivity to fire. We used the following formula based on this Table:

All species with low confidence, one dot $(*)$, were assigned $U$ Species with " 0 " and higher confidence $(* *$ or $* * *)$ were assigned $\mathrm{N}$ Species with - or + and higher confidence $(* *$ or $* * *)$ were assigned SI or SD, respectively Species with - - or ++ and higher confidence (** or $* * *)$ were assigned Inc or Dec, respectively.

Most species not included by Steel et al. (2010) were given U but some received scores based on additional information. Of these, we assigned Gray Flycatcher, Brewer's Sparrow, and Sage Sparrow subscore SD based on reported benefits of fire to sagebrush communities by Baker (2006) and other sources. Purple Martin was assigned SD based on benefits of fire to creating more snags and potential nest sites (as with Violet-green Swallow; Steel et al. 2010) and California Thrasher was assigned SD based on benefits of fire to chaparral species (as in Wrentit; Steel et al. 2010).

Note no species were assigned GI. We considered this appropriate for birds in comparison with some other organisms, and due to uncertainty in predicting fire regimes in the Sierra Nevada.

This resulted in: Inc -2 species, $\mathrm{SI}-23$ species, $\mathrm{N}-20$ species, $\mathrm{SD}-52$ species, Dec -10 species, and $\mathrm{U}-35$ species, thus weighting results toward benefits to Sierra species based on increased fire. 
The increase is severe weather events and increased rates of snowpack melt results in predictions for more flood events in the Sierra Nevada (Hayhoe et al. 2004, Das et al. 2011). We assigned score SI for 8 species that rely on streams or rivers that might have reproduction affected by flooding from a greater incidence of such events. These species were: Wood Duck, Harlequin Duck, Common Merganser, Killdeer, Spotted Sandpiper, Black Swift, Pacific Wren, and American Dipper. Seven of these 8 species scored as $\mathrm{N}$ or $\mathrm{U}$ for sensitivity for fire based on Steel et al. (2010). Pacific Wren scored as SI so we assigned Inc to this species due to the combined potential effects of increased fire and increased flooding.

We decided that potential increases or decreases in winds in the Sierra Nevada should not affect birds or their habitats severely. Pathogens such as West Nile Virus have the potential to affect birds, but it is unknown how climate change will in turn affect affliction rates. Assuming drying in the Sierra Nevada, the rates of mosquito-borne viruses, at least, might be predicted to decrease.

\section{C2d. Sensitivity; Dependence on ice, ice-edge, or snow-cover habitats}

Available CCVI Codes (Young et al. 2011) are: GI, Inc, SI, and N.

From the guidelines (Young wt al. 2011): "This factor pertains to a species' dependence on habitats associated with ice (e.g., sea ice, glaciers) or snow (e.g., long-lasting snow beds, avalanche chutes) throughout the year or seasonally during an essential period of the life cycle. "Range" refers to the range within the assessment area."

Scoring is according to theoretical percentage dependence on ice and snow: GI $>80 \%$, Inc 50$80 \%$, SI $10-49 \%, \mathrm{~N}<10 \%$.

The Nevada State CCVI (Young et al. 2009) gave N to all species except Gray-crowned and Black Rosy-Finches, which were assigned SI.

We followed this approach for Gray-crowned Rosy-Finch, assigning SI, and also assigned Inc to White-tailed Ptarmigan because it does not disperse down-slope as much as the rosy-finch. No other species were considered to be dependent enough on snow to receive scores other than $\mathrm{N}$. Borderline species included Horned Lark and American Pipit, which breed in subalpine zones, but we retained subscores of $\mathrm{N}$ for these. We also considered SI for Sooty Grouse based on decreased snow possibly decreasing thermal cover for this species. The BNA account (Poole 2005) has conflicting information about this, including this statement: "snow roosting appears to be less common than in other northern tetraonines" so we retained subscore $\mathrm{N}$ for this species. Great Gray Owl drops to lower, less snowy elevations in the Sierra Nevada during winter in order to feed, so we retained code $\mathrm{N}$ for this species as well.

\section{C3. Sensitivity; Restriction to Uncommon Geological Features or Derivatives}

Available CCVI Codes (Young et al. 2011) are: Inc, SI, N, SD, and Dec.

From guidelines (Young et al. 2011): "This factor pertains to a species' need for a particular soil/substrate, geology, water chemistry, or specific physical feature (e.g., caves, cliffs, active sand dunes) 
for reproduction, feeding, growth, or otherwise existing for one or more portions of the life cycle (e.g., normal growth, shelter, reproduction, seedling establishment). It focuses on the commonness of suitable conditions for the species on the landscape, as indicated by the commonness of the features themselves combined with the degree of the species' restriction to them. Climate envelopes may shift away from the locations of fixed (within at least a 50 year timeframe) geological features or their derivatives, making species tied to these uncommon features potentially more vulnerable to habitat loss from climate change than are species that thrive under diverse conditions.

This factor does NOT include habitat preferences based on temperature, hydrology, or disturbance regime, as these are covered elsewhere in the Index. For example, species dependent on springs or ephemeral pools should not be scored as more vulnerable for this factor solely on that basis (addressed under Factor C2bii: Physiological Hydrological Niche)... This factor also does NOT include microhabitat features such as stream riffles or basking rocks. Finally, this factor does NOT include biotic habitat components; for example, species that require features such as tree snags or a particular type/condition of plant community (e.g., old growth forest) should not be scored as more vulnerable for this factor. If the idea of specificity to soil/substrate, geology, or specific physical features is not relevant to the species (e.g., many birds and mammals), choose Somewhat Decrease."

The default coding for birds should be SD.

The Nevada State CCVI (Young et al. 2009) scored most birds as SD. They gave a morevulnerable code (SI) to species that nest on cliffs and they gave code "N" or "SI" to a few other species for various reasons. They did not give Inc or Dec to any species.

We followed this approach for cliff-breeding species and assigned scores SI to Golden Eagle, Peregrine Falcon, Prairie Falcon, Barn Owl, Black Swift, White-throated Swift, Belted Kingfisher, Common Raven, Northern Rough-winged Swallow, Cliff Swallow, Rock Wren, and Canyon Wren. We assigned subscore N to Great Horned Owl, Say's Phoebe, and Barn Swallow because only some birds nest on cliffs or crevices.

Other species that might depend on specific geologic features include White-tailed Ptarmigan, Killdeer, Common Nighthawk, Common Poorwill, Horned Lark, and Gray-crowned Rosy-Finch but we concluded that such vulnerabilities of these species are better covered by other categories.

For the code "Dec" the guidelines say: "Highly generalized relative to dependence upon geological features or derivatives, i.e., the species is described as a generalist and/or a significant proportion of its occurrences have been documented on substrates or in waters that represent opposite ends of the spectrum of types within the assessment region (e.g., many occurrences known from both acidic and basic soils or waters, or from both sandy and clay soils). Species such as common yarrow (Achillea millefolium) and coyote (Canis latrans) should be assigned to this category."

We assigned subscore Dec to 11 species due to their ubiquitous distribution and/or seemingly adaptable nature: Red-tailed Hawk, Mourning Dove, Northern Flicker, Black-billed Magpie, Bushtit, American Robin, California Towhee, Dark-eyed Junco, Brewer's Blackbird, Brownheaded Cowbird, and House Finch.

The remainder of the species, including all of those restricted to forest or other specific habitats, were assigned subscore SD. 


\section{C4a. Sensitivity; Reliance on Interspecific Interactions; Dependence on other species to generate habitat}

Available CCVI Codes (Young et al. 2011) are: GI, Inc, SI, and N.

From the guidelines: "Habitat refers to any habitat (e.g., for reproduction, feeding, hibernation, seedling establishment, etc.) necessary for completion of the life cycle, including habitats used only on a seasonal basis. For plants, creation of habitat conditions necessary for seedling establishment should be considered here; nutritional relationships necessary for seedling establishment (e.g., parasitic or obligately myco-heterotrophic plants) should be considered under C4e."

For code GI the guidelines further state: "The following examples are cases in which species depend on others to generate habitat, although the species generating the habitat is not necessarily highly vulnerable to climate change throughout its range. In harsh environments, the presence of a single ecosystem engineer can create habitat for species for which abiotic conditions would otherwise be unsuitable (e.g., Spartina alterniflora in eastern North American salt marshes). There are also examples of "habitat structure specialists" among arthropods: several insect species (e.g., the beetle Onthophilus giganteus) are entirely dependent on southeastern pocket gopher (Geomys pinetis) tunnels for habitat, and the spider Masoncus pogonophilus depends on habitat provided by colony chambers of the Florida harvester ant (Pogonomyrmex badius) (Cushing 1997). Kirtland's warbler (Dendroica kirtlandii) is dependent on jack pine (Pinus banksiana) for its nesting habitat."

Note that dependence on another species must first be established, and then the coding is dependent on the vulnerability of that independent species (not the bird species) to climate change. Codes Inc and SI would be applied to bird species dependent on other species that receive these codes.

The Nevada State CCVI (Young et al. 2009) gave N to most bird species as appropriate. They gave SI to quite a few species dependent on specific xeric, pinyon-juniper, or marsh habitats and GI-Inc to species dependent on sage-brush habitats, due to dependence on specific plant species in those habitats. Yellow-billed Cuckoo was assigned SI-N due to reliance on willow or cottonwood.

Following this approach, we identified only four species in the Sierra Nevada to assign SI based on reliance on specific plant species or habitats to nest or forage:

Pinyon Jay, due to reliance on specific pinyon-juniper habitats/species to nest and forage Brewer's Sparrow, due to reliance on specific sagebrush habitats/species to nest and forage Sage Sparrow, due to reliance on specific sagebrush habitats/species to nest and forage Yellow-headed Blackbird, due to reliance on tule marsh habitats to nest

The remaining species were assigned $\mathrm{N}$.

\section{C4b. Sensitivity; Reliance on Interspecific Interactions; Dietary Versatility}

Available CCVI Codes (Young et al. 2011) are: Inc, SI, N, and SD. 
From guidelines:" This factor pertains to the diversity of food types consumed by animal species. Dietary specialists are more likely to be negatively affected by climate change than are species that readily switch among different food types."

For code Inc the guidelines say: "Completely or almost completely (>90\%) dependent on one species during any part of the year. For example, Clark's nutcracker (Nucifraga columbiana) depends heavily on the seeds of whitebark pine (Pinus albicaulis)". Code SI is the same but dependency is on a few species in a given guild, and $\mathrm{N}$ is for animals with flexible diet (Great Horned Owl given as an example). For code SD they say "Omnivorous diet including numerous species of both plants and animals."

The Nevada State CCVI (Young et al. 2009) assigned code $\mathrm{N}$ to all but five species, Greater Sage-Grouse (SI), Western Snowy Plover (SI-N), Yellow-billed Cuckoo (SI), American White Pelican (SI), and Phainopepla (SI).

We decided that the following species should get more-vulnerable codes than $\mathrm{N}$ in the Sierra Nevada based on information (primarily from BNA Accounts; Poole 2005) indicated morerestricted diets than other species:

White-tailed Ptarmigan (SI)

Osprey (SI)

Bald Eagle (SI)

Northern Harrier (SI)

Northern Goshawk (SI)

Yellow-billed Cuckoo (SI)

Flammulated Owl (SI)

Spotted Owl (Inc)

Great Gray Owl (Inc)

Black-chinned Hummingbird (SI)

Calliope Hummingbird (SI)

Rufous Hummingbird (Inc)

Acorn Woodpecker (SI)

White-headed Woodpecker (SI)

Black-backed Woodpecker (Inc)

Pinyon Jay (Inc)

Clark's Nutcracker (Inc)

Oak Titmouse (SI)

White-breasted Nuthatch (SI)

Pygmy Nuthatch (SI)

Marsh Wren (SI)

American Dipper (SI)

Sage Sparrow (SI)

Gray-crowned Rosy-Finch (SI)

Pine Grosbeak (Inc)

Red Crossbill (Inc)

We also assigned SD to the following species based on omnivorous and/or varied diets: 


\author{
Wild Turkey \\ Steller's Jay \\ Western Scrub-Jay \\ Black-billed Magpie \\ Common Raven \\ American Robin \\ European Starling \\ Brewer's Blackbird \\ House Sparrow
}

C4d. Sensitivity; Reliance on Interspecific Interactions; Dependence on other species for propagule dispersal

Available CCVI Codes (Young et al. 2011) are: Inc, SI, and N.

From guidelines (Young et al. 2011): "Can be applied to plants or animals. Examples: Different species of freshwater mussels can be dispersed by one to many fish species; fruit dispersal by animals."

The guidelines give further examples of species that are dispersed by others. No examples include birds or other vertebrates and they specifically say most animals can disperse on their own and should get an $\mathrm{N}$.

The Nevada State CCVI (Young et al. 2009) gave all birds an N and we followed this approach.

\title{
C4e. Sensitivity; Reliance on Interspecific Interactions; Forms part of interspecific interaction not covered by $\mathbf{C} 4 \mathbf{a}-\mathbf{d}$.
}

Available CCVI Codes (Young et al. 2011) are: Inc, SI, and N.

From guidelines (Young et al. 2011): "Can be applied to plants or animals. Refers to interactions unrelated to habitat, seedling establishment, diet, pollination, or propagule dispersal. For example, an acacia bush requiring an ant colony for protection against herbivores. Here an interspecific interaction can include mutualism, parasitism, commensalism, or predator-prey relationship."

For Inc the guidelines say "Requires an interaction with a single other species for persistence.: and for SI they say: "Requires an interaction with a one member of a small group of taxonomically related species for persistence."

The Nevada State CCVI (Young et al. 2009) gave all birds an $\mathrm{N}$ and we followed this approach.

\section{C5a. Sensitivity; Genetic Factors; Measured genetic variation.}

Available CCVI Codes (Young et al. 2011) are: Inc, SI, N, and SD.

From guidelines (Young et al. 2011): "Species with less standing genetic variation will be less able to adapt because the appearance of beneficial mutations is not expected to keep pace with the rate of 21st century climate change. Throughout this question, "genetic variation" may refer neutral marker variation, 
quantitative genetic variation, or both. To answer the question, genetic variation should have been assessed over a substantial proportion of a species' range. Because measures of genetic variability vary across taxonomic groups, there cannot be specific threshold numbers to distinguish among the categories. The assessor should interpret genetic variation in a species relative to that measured in related species to determine if it is low, high, or in between."

For specific coding it is recommended that codes be given to species with genetic variation: Inc - very low, SI low, $\mathrm{N}$ average, and SD high. The Unknown code "U" apparently should be used here if this question cannot be answered with direct data.

The Nevada State CCVI (Young et al. 2009) assigned U to all species except Trumpeter Swan, which was coded SI based on direct molecular evidence of their genetic variation.

We considered how much genetic variation is shown across the species and inferred that variable species have more genetic variation within the Sierra Nevada Region. For example, species like California Quail, Hairy Woodpecker, Pygmy Nuthatch, and Fox Sparrow show wide geographic variation within the west and could be assigned SD, whereas restricted and monotypic species such as Greater Roadrunner and Nuttall's and White-headed woodpeckers, could be assigned more vulnerable codes. But we decided to assign all species $U$ without specific molecular evidence on genetic variation (see also category c5b on bottlenecks).

We assigned subscores to the following species based on specific studies on genetic variation in the Sierra Nevada Region:

Great Gray Owl. Hull et al. (2010) indicate a dramatic reduction in genetic diversity due to recent bottleneck of California population so assigned subscore SI.

White-headed Woodpecker. Alexander and Burns (2006) give no indication that variability in California has been reduced we assigned subscore $\mathrm{N}$.

Black-backed Woodpecker. Pierson (2013) considered genetic diversity in Western North America high so we assigned code $\mathrm{N}$; we considered SD as well.

Wrentit. Burns and Barhoum (2006) give no indication that variability in California has been reduced we assigned subscore $\mathrm{N}$.

California Thrasher. Sgariglia and Burns (2006) give no indication that variability in California has been reduced we assigned subscore $\mathrm{N}$.

Gray-crowned Rosy-Finch. Drovetski et al. (2009a) considered genetic diversity in California high so we assigned code $\mathrm{N}$.

Pine Grosbeak - Drovetski et al. (2009b) indicate a reduction in genetic diversity in California populations as compared with others so score changed to "SI".

C5b. Sensitivity; Genetic Factors; Occurrence of bottlenecks in recent evolutionary history.

Available CCVI Codes (Young et al. 2011) are: Inc, SI, and N.

This code is only to be used for species in which genetic variation (column C5a) was coded as U.

From guidelines (Young et al. 2011): "In the absence of rangewide genetic variation information (C5a), this factor can be used to infer whether reductions in species-level genetic variation that would potentially impede its adaptation to climate change may have occurred. Only species that suffered 
population reductions and then subsequently rebounded qualify for the Somewhat Increase or Increase Vulnerability categories."

For Inc there should be: "Evidence that total population was reduced to $\leq 250$ mature individuals, to one occurrence, and/or that occupied area was reduced by $>70 \%$ at some point in the past 500 years." for $\mathrm{SI}$ it is the same but $251-1.000$ individuals and $30-70 \%$ of occupied area, and for $\mathrm{N}$ there is no evidence for population reductin to the extent indicated for SI.

The Nevada State CCVI (Young et al. 2009) assigned U to all species except Columbian Sharptailed Grouse (SI) and Trumpeter Swan (N/A).

We assigned $\mathrm{N}$ to all species except those listed under $\mathrm{C} 5 \mathrm{a}$ (N/A) and the following as based on widely know recent changes in population (information from BNA Accounts; Poole 2005):

Osprey (Inc) - recovering from population lows due to DDT contamination.

Bald Eagle (Inc) - recovering from population lows due to DDT contamination.

Northern Goshawk (SI) - recovering from population lows due to DDT contamination.

Peregrine Falcon (Inc) - recovering from population lows due to DDT contamination.

Prairie Flacon (SI) - recovering from population lows due to DDT contamination.

Evening Grosbeak (SI) - cyclical populations that have increased

\section{C6. Sensitivity; Phenological response to changing seasonal temperature or precipitation dynamics.}

Available CCVI Codes (Young et al. 2011) are: Inc, SI, N, and SD.

From guidelines (Young et al. 2011): "Recent research suggests that some phylogenetic groups are declining due to lack of response to changing annual temperature dynamics (e.g., earlier onset of spring, longer growing season), including European bird species that have not advanced their migration times (Møller et al. 2008), and some temperate zone plants that are not moving their flowering times (Willis et al. 2008) to correspond to earlier spring onset. This may be assessed using either published multispecies studies such as those cited above or large databases such as that of the U.S. National Phenology Network."

Specific recommendations range from "Seasonal temperature or precipitation dynamics within the species' range show detectable change, but phenological variables measured for the species show no detectable change" for Inc, to "Seasonal temperature or precipitation dynamics within the species' range show detectable change, and phenological variables measured for the species show detectable change which is significantly greater than that of other species in similar habitats or taxonomic groups" for $\mathrm{SD}$, with $\mathrm{SI}$ and $\mathrm{M}$ falling in between.

The Nevada State CCVI (Young et al. 2009) assigned U for all species. In the lack of direct evidence we have taken the same approach for the Sierra Nevada Region.

\section{D1. Documented or Modeled Response to Climate Change; Documented response.}

Available CCVI Codes (Young et al. 2011) are: GI, Inc, SI, N, SD, and Dec.

From guidelines (Young et al. 2011): Documented or modeled response to climate change (e.g., range contraction or phenology mismatch with critical resources). NOTES: This factor pertains to the degree to 
which a species is known to have responded to recent climate change based on published accounts in the peer-reviewed literature. Time frame for the reduction or increase is 10 years or three generations, whichever is longer. Some examples include population declines due to phenology mismatches between species and critical food or pollinator resources, e.g., great tits (Parus major) or pied flycatchers (Ficedula hypoleuca) with winter moth (Operophtera brumata) caterpillars, or honey-buzzards (Pernis apivorus) with wasps. Note that not all responses to climate change necessarily indicate vulnerability. Species that respond to climate change by shifting (but not contracting) their range, for example, show adaptability to climate change and should be scored as Neutral for this factor. Similarly, species that respond by changing their phenology (without a related decline in population) should also be scored as Neutral.

Choices vary from GI - range reduced by $>70 \%$ in region over past 10 years; Inc $30-70 \%$ reduction; SI 10-30\%; $\mathrm{N}<10 \%$ reduction or increase; SD 10-30\% increase; Dec $>30 \%$ increase. Since most or all birds on our list have generations each year we will consider this as reductions or decreases within the past 10 years.

The Nevada State CCVI (Young et al. 2009) scored all species with U indicating that they could not find anything on responses to climate change in Nevada.

We assigned codes based on Tingley et al. (2012). The primary resource for preliminary codes was the Grinnell Resurvey for the Yosemite Transect, using Table S2, which supplies data on whether or not lower and upper elevational limits have shifted upslope or downslope during the past 100 years along three transects, Northern, Central, and Southern, in the Yosemite area of the Sierra Nevada region. Significant changes are listed in terms of "-" and "+" at lower and upper limits, thus a code of "++" (shifted upward at both lower and upper limits) or "--" (shifted downward at both limits) indicates that both boundaries have shifted and the species was assigned code $\mathrm{N}$ according to the guidelines. A pattern of -+ indicates expanding range and +indicates contracting range, as do -NS and NS+. These codes in Table S2 are given for three parameters, 1) actual historical changes and whether or not these changes would be predicted based on 2) temperature and 3) moisture change models. Overall, the data predict that temperature effects should result in expanded ranges upslope ( + in the table) whereas moisture effects should be to contract and change ranges downslope (- in the table). Thus, range changes predicted as upslope for temperature and downslope for moisture can be inferred more to have resulted from climate change, whereas opposite predictions may be due to other factors.

Because of some assumptions using these data we have taken a conservative approach in using them for our assignment of CCVI subscores. We incorporated data for coding only for species that have indications that either temperature or moisture have resulted in these changes, and have only used codes "SD" and "SI" in such cases. Each transect was scored as either indicating contracting range, indicating reduced range, or neutral based on indications consistent with climate change. Occasionally climate predicted both lower and upper elevational changes on the same transect (e.g., a downward elevational expansion at the lower limit predicted by moisture and an upward expansion at the upper limit predicted by temperature) and these transects received two scores. If there was no range expansion or contraction during the past 100 years (NSNS, ++, or --) the species receives a neutral score for that transect.

For coding, we assigned SI or SD to species where at least one transect indicated contraction or expansion, respectively, and all other transects were neutral or lack data. SD or SI is also coded for species in which two transects (or two indications on the same transect) predict one change 
based on climate and the third predicts the other. We decided not to assign GI, Inc, or Dec based on predicted changes were on two or more transects but retained SI or SD to maintain a

conservative approach (see above). We gave $\mathrm{N}$ for species with two or more transects as neutral and no transects indicating contraction or expansion, and to species with one transect indicating expansion another indicating contraction, and the third neutral or lacking data. We gave $U$ to species with no change based on just one transect due to insufficient data to support a code of $\mathrm{N}$, as well as species not treated by Tingley et al. (2012).

This resulted in the following counts, which seems to be fairly balanced: SI $-29, \mathrm{~N}-32$, SD $24, \mathrm{U}-86$.

Based on a survey of additional specific literature (e.g., Wang 2002, Bland 2008, Siegel et al. 2008, Nivens and Butcher 2009, Steel et al. 2010, Pereya 2011) and BNA Accounts (Poole 2005) we considered subscore updates but information from these references either supported the scores already given or did not result in enough evidence to change scores based on the above standardized method. Many additional published papers considering effects of cilmate change on migration phenology but change in migration timing was not considered of enough impact to birds in the Sierra Nevada region to affect our subscores.

\section{D2. Documented or Modeled Response to Climate Change; Modeled future (2050) change in range or population size.}

All six codes are available: GI, Inc, SI, N, SD, and Dec.

From guidelines (Young et al. 2011): This factor can include both distribution models and population models. Models should be developed based on reasonably accurate locality data (error $<5 \mathrm{~km}$ ) using algorithms that are supported by peer-reviewed literature. Areas of obvious overprediction should be removed from current and predicted future distributions. Projections should be based on "middle of the road" climate scenarios for the year 2050. Range size should be based on "extent of occurrence" sensu IUCN Red List. Population models should be based on known processes as described in peer-reviewed literature. Examples include (a) phenological changes that are likely to result in a mismatch with critical dietary, pollination, or habitat resources (Visser and Both 2005) or (b) documented narrow temperature tolerances and thermal safely levels, particularly in insects (Deutsch et al. 2008, Calosi et al. 2008).

Choices vary from GI - range disappears or population predicted to exterminate within area; Inc 50-99\% disappearance; SI 20-50\%; N <20\% disappearance or increase; SD 20-50\% increase; Dec $>50 \%$ increase.

PRBO Conservation Science (2011) has recently reviewed documented evidence for response of birds to climate change in California, including the Sierra Nevada. We examined PRBO's range maps derived from their modeling at http://data.prbo.org/cadc/tools/ccweb2/. The maps indicate both range changes and changes in abundance within current range.

These maps show current breeding distribution and predicted distribution in 2070 based on the predictions of two climate models GFDL and CCSM. These two models are from separate climate groups which based predictions on separate climatic variables than those used by Thorne et al. (2012) for our assessment. PRBO predictions based on the GFDL model are generally 
larger (predicting 41-43\% change in ranges) than those of the CCSM model (29-32\% changes) but both predictions will be considered in our scoring.

PRBO's modeling is for the entire state of California. we thus assessed changes for each species within the Sierra Nevada region visually. These predictions are also for changes through 2070 rather than 2050 (in the CCVI matrix) so we assigned codes conservatively. We primarily examined range-change but factored in abundance changes to some extent as well, e.g., some species lose range at low elevations but increase abundance at high elevations and we tended to score these species as $\mathrm{N}$ rather than SI.

We then cross-checked preliminary codes based on PRBO Conservation Science (2011) with the database provided by Gardali et al. (2012) at http://data.prbo.org/apps/bssc/index.php?page=climate-change-vulnerability and with the information provided by Butcher and Niven (2009). The predictions of these two resources pertain to the state of California 100 years into the future and thus do not pertain that specifically to changes in the Sierra Nevada Region through 2050. However, when large discrepancies were encountered between the results of our mapping and Gardali et al. 2012 we considered adjusting the code unless only a small proportion of the California range occurred in the Sierra Nevada region.

Based on this strategy the following codes were assigned to category D2: GI - 1 species (Vesper Sparrow), Inc - 10, SI - 47, N - 51, SI - 42, Dec - 13. Five of our species were not treated by PRBO: White-tailed Ptarmigan, Wilson's Snipe, Sooty Grouse, Northern Flicker, and Marsh Wren. So scoring of these species in D2 were based on other resources if present, and were left as $\mathrm{U}$ for columns D3 and D4 (see below).

\section{D3. Documented or Modeled Response to Climate Change; Overlap of modeled future (2050) range with current range}

Available CCVI Codes (Young et al. 2011) are:: GI, Inc, SI, and N.

From guidelines (Young et al. 2011): "Distribution models of current and projected future ranges should meet standards described in the notes for D2. Overlap is calculated as the percent of the current range represented by an intersection of the predicted future and current ranges. If the range disappears or declines > 70\% within the assessment area, such that factor D2 is coded as "Greatly Increase Vulnerability", this factor should be skipped to avoid double-counting model results."

The coding for this column is strongly tied with that for column D2 - we used the same approach regarding the maps presented by PRBO Conservation Science (2011) as documented above under D2. Category D2 deals with loss/gain of range within the area whereas coding for D3 responds to the question how much overlap there is in current and future-predicted ranges. GI indicates no overlap, Inc indicates $<30 \%$ overlap; SI $30-60 \%$ overlap; and $\mathrm{N}>60 \%$ overlap. Species whose ranges are neutral or increase but do not lose anything from the current range score as N. Those that score as SI or Inc have lost $>30 \%$ of areas where they now occur. Narrow elevational-band species may increase range upslope but with little overlap in current and future ranges and are assigned GI or Inc despite receiving an SD or Dec (expanding range) under D2. 
Based on this strategy the following codes were assigned to category D3: Inc $-14, \mathrm{SI}-38, \mathrm{~N}-$ $109, \mathrm{U}-5$.

\section{D4. Documented or Modeled Response to Climate Change; Occurrence of protected areas in modeled future (2050) distribution}

Available CCVI Codes (Young et al. 2011) are:: Inc, SI, and N.

From guidelines (Young et al. 2011): " "Protected area" refers to existing parks, refuges, wilderness areas, and other designated conservation areas that are relatively invulnerable to outright habitat destruction from human activities and that are likely to provide suitable conditions for the existence of viable populations of the species. Models of current and projected future ranges should meet standards described in the notes for D2. Modeled future distribution may refer to a single season (e.g., breeding season distribution or winter distribution) for migratory species. This factor considers ranges and protected areas within the assessment area only."

The coding for this column is strongly tied with that for column D2 (see documentation there). Category D3 assigns codes based on the question how much overlap there is in future-predicted ranges and current protected areas, with Inc indicating <5\% overlap; SI 5-30\%; and N > 30\% overlap wit hcurrent protected areas. Scoring was based primarily on examination of the PRBO maps for changes in Yosemite and Sierra-Kings Canyon National Parks, which encompass > 95\% of the protected areas in the Sierra Nevada Region. Other smaller areas (e.g., Devils Postpile National Monument) will not make a difference in the assessment and we have considered all National Forest lands (including their Wilderness-designated areas) as not necessarily protected. The Kern River Preserve (protected riparian habitat along lower fork of the Kern River) affected the coding of one our species, Yellow-billed Cuckoo, resulting in a score change from Inc to SI.

Since Yosemite and Sierra-Kings Canyon parks encompass about 8-10\% of the Sierra Nevada range, most to all widespread species will be assigned SI, indicating 5-30\% of predicted future range will be protected. Others that do not extend high up into the Sierra were assigned Inc $(<$ $5 \%$ ) and some species with higher-elevation distributions, a greater proportion of which occurred in the two national parks, were assigned $\mathrm{N}$ ( $>30 \%$ in protected areas).

Based on this strategy the following codes were assigned to category D4: Inc $-61, \mathrm{SI}-94$, $\mathrm{N}-7, \mathrm{U}-5$.

\section{Literature Cited}

Alexander, M. P., and K. J. Burns. 2006. Intraspecific phylogeography and adaptive divergence in the White-headed Woodpecker. Condor 108:489-508.

Baker, W.L. 2006. Fire and restoration of sagebrush ecosystems. Wildlife Society Bulletin 34:177-185.

Bland, J. D. 2008. Mount Pinos Sooty Grouse (Dendragapus fuliginosus howardi). Pages 102106 in W. D. Shuford and T. Gardali, editors. California bird species of special concern: A ranked assessment of species, subspecies, and distinct populations of birds of 
immediate conservation concern in California. Western Field Ornithologists and California Department of Fish and Game, Camarillo and Sacramento, California.

Burns, K. J., and D.N. Barhoum. 2006. Population-level history in the Wrentit (Chamaea fasciata): implications for comparative phylogeography in the California Floristic Province. Molecular Phylogenetics and Evolution 38:117-129.

Cayan, D. R., E.P. Maurer, M. D. Dettinger, M. Tyree, and K. Hayhoe. 2008. Climate change scenarios for the California region. Climatic Change 87 (Suppl 1):S21-S42. doi 10.1007/s10584-007-9377-6.

Das, T., M. D. Dettinger, D. R. Cayan, and H. G. Hidalgo. 2011. Potential increase in floods in California's Sierra Nevada under future climate projections. Climatic Change 109 (Suppl 1):S71-S94

Drovetski, S.V, R.M. Zink, and N. A. Mode. 2009a. Patchy distributions belie morphological and genetic homogeneity in rosy-finches. Molecular Phylogenetics and Evolution 50:437445.

Drovetski, S.V., R. M. Zink, P. G. P. Ericson, and I. V. Fadeev. 2009b. A multilocus study of Pine Grosbeak phylogeography supports the pattern of greater intercontinental divergence in Holarctic boreal forest birds than in birds inhabiting other high-latitude habitats. Journal of Biogeography 37:696-706.

Flint, A.L., and Flint, L.E., 2007, Application of the basin characterization model to estimate inplace recharge and runoff potential in the Basin and Range carbonate-rock aquifer system, White Pine County, Nevada, and adjacent areas in Nevada and Utah: U.S. Geological Survey Scientific Investigations Report 2007-5099, 20 p.

Fontaine, J.B., D.C. Donato, W.D. Robinson, B.E. Law, and J.B. Kauffman. 2009. Bird communities following high-severity fire: Response to single and repeat fires in a mixedevergreen forest, Oregon, USA. Forest Ecology and Management 257:1496-1504.

Gaines, D. 1992. Birds of Yosemite and the East Slope. 2nd printing. Artemisia Press, Lee Vining, California.

Gardali T, N. E. Seavy, R. T. DiGaudio, and L. A. Comrack. 2012. A climate change vulnerability assessment of California's at-risk birds. PLOS ONE 7(3): e29507. doi:10.1371/journal.pone.0029507

Hayhoe K, D. Cayan, C. B. Field, P. C. Frumhoff, E. P. Maurer, N. L. Miller, S. C. Moser, S. H. Schneider, K. N. Cahill, E, E. Cleland, L. Dale, R. Drapek, R. M. Hanemann, L. S. Kalkstein, J. Lenihan, C. K. Lunch, R. P. Neilson, S.C. Sheridan, and J. H. Verville. 2004. Emissions pathways, climate change, and impacts on California. Proceedings of the National Academy of Sciences of the United States of America 101:12422-12427.

Hull, J.M., J.J. Keane, W. K. Savage, S. A. Godwin, J.A. Shafer, E. P. Jepsen, R. Gerhardt, C. Stermer, and H. B. Ernest. 2010. Range-wide genetic differentiation among North American great gray owls (Strix nebulosa) reveals a distinct lineage restricted to the Sierra Nevada, California. Molecular Phylogenetics and Evolution 56:212-221

Krawchuk M.A., M.A. Moritz, M-A, Parisien, J. Van Dorn, and K. Hayhoe. 2009. Global pyrogeography: the current and future distribution of wildfire. PLoS ONE 4(4): e5102. doi:10.1371/journal.pone.0005102

Lutz, J.A., J.W. van Wagtendonk, and J.F. Franklin. 2010. Climatic water deficit, tree species ranges, and climate change in Yosemite National Park. Journal of Biogeography 37:936950 . 
Miller, J.D., H.D. Stafford, M. Crimmins, and A.E. Thode. 2009. Quantitative Evidence for Increasing Forest Fire Severity in the Sierra Nevada and Southern Cascade Mountains, California and Nevada, USA. Ecosystems 12:16-32.

Niven, D.K. and D.S. Butcher. 2009. Northward Shifts in the Abundance of North American Birds in Early Winter: A Response to Warmer Winter Temperatures? National Audubon Society report.

Pereyra, M.A. 2011. Effects of snow-related environmental variation on breeding schedules and productivity in a high altitude flycatcher (Empidonax oberholseri). Auk 128:746-58

Pierson J.C., F. W. Allendorf, P. Drapeau, and M.K. Schwartz. 2013. Breed locally, disperse globally: Fine-scale genetic structure despite landscape-scale panmixia in a firespecialist. PLoS ONE 8(6): e67248. doi:10.1371/journal.pone.0067248

Poole, A. (Editor). 2005. The Birds of North America Online: http://bna.birds.cornell.edu/BNA/. Cornell Laboratory of Ornithology, Ithaca, New York.

PRBO Conservation Science. 2011. Projected Effects of Climate Change in California: Ecoregional Summaries Emphasizing Consequences for Wildlife. Version 1.0. http://data.prbo.org/apps/bssc/ climate change (Accessed 15 November 2011).

Sgariglia, E. A., and K. J. Burns. 2003. Phylogeography of the California Thrasher (Toxostoma redivivum) based on nested-clade analysis of mitochondrial-DNA variation. Auk 120:346-361.

Siegel, R. B., R. L. Wilkerson, and D. F. DeSante. 2008. Extirpation of the Willow Flycatcher from Yosemite National Park. Western Birds 39:8-21.

Siegel, R. B., R. L. Wilkerson, J. F. Saracco, and Z. L. Steel. 2011. Elevation ranges of birds on the Sierra Nevada's west slope. Western Birds 42:2-26.

Smucker, K.M., R.L. Hutto, and B.M. Steel. 2005. Changes in bird abundance after wildifre: Importance of fire severity and time since fire. Ecological Applications 15:1535-1549.

Steel, Z. L., M. L. Bond, R. B. Siegel, and P. Pyle. 2012. Avifauna of Sierra Nevada Network parks: Assessing distribution, abundance, stressors, and conservation opportunities for 145 bird species. Natural Resource Report NPS/SIEN/NRR - 2012/506. National Park Service, Fort Collins, Colorado.

Thorne, J. H., R. Boynton, T. N. Le, A. Flint, and L. Flint. 2012. Development and application of downscaled hydroclimatic predictor variables for use in cross-sector climate vulnerability and assessment studies. California Energy Commission. CEC-500-2011-009.

Tingley, M. W., M. S. Koo, C. Moritz, A. C. Rush, and S. R. Beissinger. 2012. The push and pull of climate change causes heterogeneous shifts in avian elevational ranges. Global Change Biology 18:3279-3290. doi: 10.1111/j.1365-2486.2012.02784.x

Wang, G., N. T. Hobbs, K. M. Giesen, H. Galbraith, D. S. Ojima, and C. E. Braun. 2002. Relationships between climate and population dynamics of White-tailed Ptarmigan Lagopus leucurus in Rocky Mountain National Park, Colorado, USA. Climate Research 23:81-87.

Westerling, A.L., B.P. Bryant, H.K. Preisler, T.P. Holmes, H. Hidalgo, T. Das, and S. Shrestha 2011: Climate Change and Growth Scenarios for California Wildfire. Climatic Change 109(s1):445-463.

Young, B. E., E. Byers, K. Gravuer, K. R. Hall, G. A. Hammerson, A. Redder, K. Szabo, and J. E. Newmark. 2009. Using the NatureServe Climate Change Vulnerability Index: a Nevada case study. NatureServe, Arlington, Virginia. 
Young, B. E., E. Byers, K. Gravuer, K. Hall, G. Hammerson, and A. Redder. 2011. NatureServe guidelines for using the NatureServe Climate Change Vulnerability Index (Release 2.1, 7 April 2011). NatureServe, Arlington, Virginia.

Young, B. E., K. R. Hall, E. Byers, K. Gravuer, G. Hammerson, A. Redder, and K. Szabo. 2012. Rapid assessment of plant and animal vulnerability to climate change. Pages 129-152 in J. Brodie, E. Post, and D. Doak, eds., Conserving wildlife populations in a changing climate. University of Chicago Press, Chicago, Illinois.

Zeiner, D. C., W. F. Laudenslayer, K. E. Mayer, and M White. 1990. California's Wildlife, Volume II, Birds. State of California Department of Fish and Game, Sacramento, California. 
Appendix 3. Summary rationale for scoring climate change vulnerability of Sierra Nevada bird species with NatureServe's Climate Change Vulnerability Index (CCVI)

Please click here to download file 'appendix3.xls'. 